\title{
ADAPTAÇÃO DE UM PULVERIZADOR CONVENCIONAL PARA A APLICAÇÃO LOCALIZADA DE DEFENSIVOS AGRÍCOLAS
}

\author{
Júlio César Dalla Mora Esquerdo
}

\begin{abstract}
Dissertação de Mestrado apresentada à Escola Superior de Agricultura "Luiz de Queiroz", Universidade de São Paulo, para obtenção do título de Mestre em Agronomia, Área de Concentração: Máquinas Agrícolas.
\end{abstract}

\author{
P I R A C I C A B A \\ Estado de São Paulo - Brasil \\ Janeiro- 2002
}




\title{
ADAPTAÇÃO DE UM PULVERIZADOR CONVENCIONAL PARA A APLICAÇÃO LOCALIZADA DE DEFENSIVOS AGRÍCOLAS
}

\author{
Júlio César Dalla Mora Esquerdo
}

Engenheiro Agrônomo

Orientador: Prof. Titular LUIZ ANTONIO BALASTREIRE

Dissertação de Mestrado apresentada à Escola

Superior de Agricultura "Luiz de Queiroz", Universidade de São Paulo, para obtenção do título de Mestre em Agronomia, Área de Concentração: Máquinas Agrícolas.

\author{
P I R A C I C A B A \\ Estado de São Paulo - Brasil \\ Janeiro - 2002
}


Dados Internacionais de Catalogação na Publicação (CIP) DIVSÃO DE BIBLIOTECA E DOCUMENTAÇÃO - ESALQ/USP

\author{
Esquerdo, Júlio César Dalla Mora \\ Adaptação de um pulverizador convencional para a a plicação \\ localizada de defensivos agrícolas / J úlio César Dalla Mora Esquerdo. - - \\ Piracicaba, 2002. \\ 98 p. : il. \\ Dissertação (mestra do) - - Escola Superior de Agric ultura Luiz de Queiroz, \\ 2002 \\ Bibliografia. \\ 1. Agricultura de precisão 2. Mapeamento 3. Pesticidas 4. Plantas \\ daninhas 5. Pulveriza dores I. Título
}


Aos meus avós, Raphael e Olga, por toda uma vida de lutas em nome de um futuro melhor aos seus filhos e netos,

Ofereço.

À José Antonio, meu pai e maior exemplo, por tornar meus caminhos mais fáceis que os seus;

À Elisa, minha mãe e grande amiga, por todo seu carinho e dedicação,

Dedico. 


\section{AGRADECIMENTOS}

Ao Professor Titular Luiz Antonio Balastreire, pela orientação neste trabalho.

Ao Departamento de Engenharia Rural da ESALQ/USP, pelos suportes pessoal e técnico.

À Fundação de Amparo à Pesquisa do Estado de São Paulo, pelo suporte financeiro.

Ao Engenheiro Eletricista Juarez Renó do Amaral e ao Técnico em Eletrotécnica Áureo Santana de Oliveira, do Laboratório de Instrumentação Agrícola do Departamento de Engenharia Rural da ESALQ/USP, pelos auxílios prestados na condução desta pesquisa.

À empresa Máquinas Agrícolas Jacto S.A., pelo empréstimo do pulverizador utilizado neste trabalho.

Ao Centro de Treinamento da AGCO, localizado nas dependências do Departamento de Engenharia Rural da ESALQ/USP, pelo empréstimo do trator utilizado na presente pesquisa.

À Usina Costa Pinto, por ceder a área para os testes do sistema desenvolvido.

Ao Engenheiro Eletricista Daniel Gurgel Penteado, pelo auxílio no desenvolvimento do programa computacional utilizado neste trabalho.

Aos amigos Domingos Guilherme P. Cerri, Fábio Henrique R. Baio e

Juliano C. Leal, pelos auxílios prestados ao longo desta pesquisa e, sobretudo, pela convivência. 
Aos Professores Drs. Thomaz Caetano C. Rípoli, Ulisses Rocha Antuniassi e Walter Francisco Molina Júnior, pelas sugestões conferidas ao aprimoramento deste trabalho.

Aos demais Professores do Departamento de Engenharia Rural da ESALQ/USP, por contribuírem ao aprimoramento profissional de seus alunos em suas disciplinas.

Aos funcionários do Departamento de Engenharia Rural da ESALQ/USP: Fernanda Barbosa, Dona Lourdes, Luiz Afonso, Francisco de Oliveira, José Geraldo Gomes e José Ferreira de Oliveira, pelos auxílios prestados.

Aos alunos do Curso de Pós-Graduação em Máquinas Agrícolas, pela convivência ao longo desses dois anos.

Aos Professores Drs. Eder Cassola Molina e Nelsi Cogo de Sá, do Instituto Astronômico e Geofísico da Universidade de São Paulo, por ceder o algoritmo de transformação de coordenadas, utilizado no presente trabalho.

Às bibliotecárias Eliana Maria Garcia Sabino e Sílvia Zinsly, pelo auxílio na organização das referências bibliográficas. 


\section{SUMÁRIO}

Página

LISTA DE FIGURAS............................................................................. ix

LISTA DE TABELAS..............................................................................

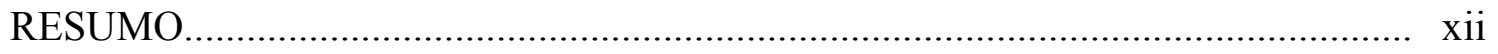

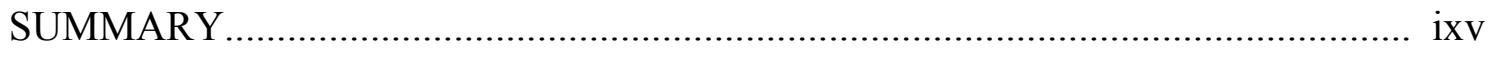

1 INTRODUÇÃO

2 REVISÃO DE LITERATURA............................................................... 4

2.1 As plantas daninhas e o controle químico................................................. 4

2.2 A Agricultura de Precisão........................................................................ 5

2.3 Os sistemas de posicionamento................................................................. 8

2.3.1 Sistemas de posicionamento baseados em laser .......................................... 8

2.3.2 Sistemas de posicionamento baseados em onda de rádio .............................. 8

2.3.3 Sistema de Posicionamento Global (GPS) ................................................... 9

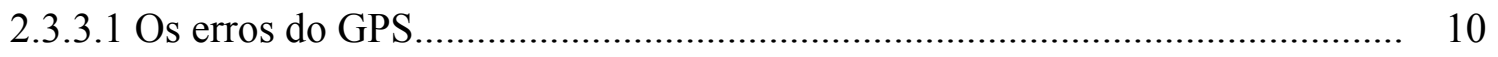

2.3.3.2 A correção diferencial do GPS (DGPS) .................................................... 11

2.4 Variabilidade espacial das plantas daninhas.................................................. 12

2.5 A redução no uso de herbicidas pelo uso da aplicação localizada ..................... 14

2.6 As estratégias de aplicação localizada.......................................................... 16

2.6.1 Aplicação em tempo real ........................................................................... 16

2.6.2 Aplicação por mapeamento................................................................. 18

2.6.2.1 Mapeamento por amostragem sistemática............................................... 18

2.6.2.2 Caminhamento ao redor das infestações.................................................... 19

2.6.2.3 Análise de imagens e sensoriamento remoto........................................... 20 
Página

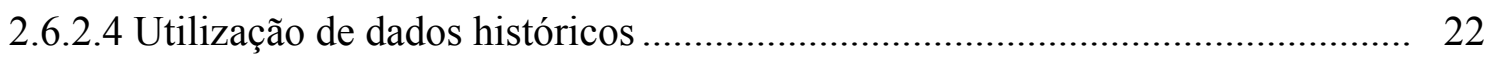

2.6.2.5 Uso de algoritmos de decisão para a criação de mapas de prescrição.............. 23

2.7 Equipamentos para aplicação localizada de defensivos agrícolas...................... 24

3 MATERIAL E MÉTODOS ....................................................................... 29

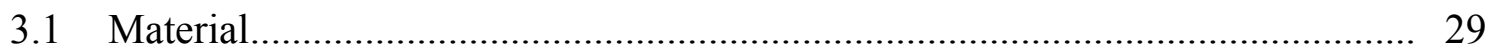

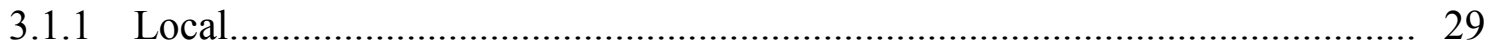

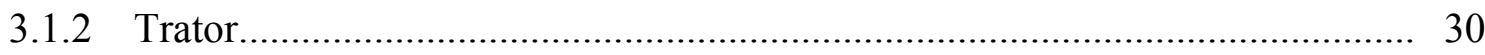

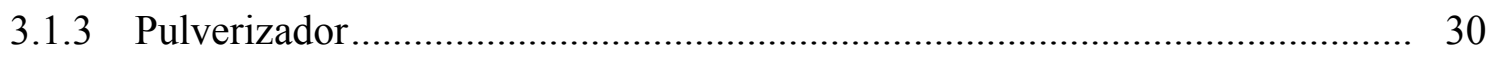

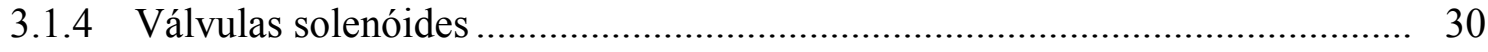

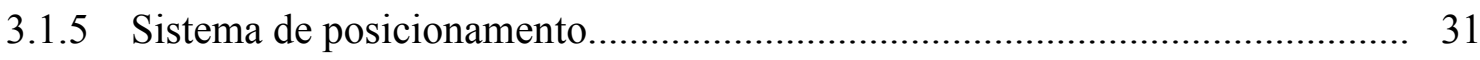

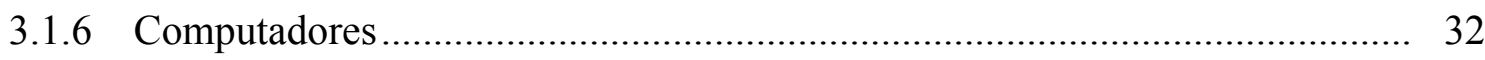

3.1.7 Equipamentos utilizados no desenvolvimento e avaliação do programa ........ 33

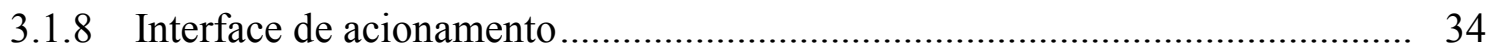

3.1.9 Equipamentos utilizados no mapeamento das plantas daninhas.................... 35

3.1.10 Equipamentos utilizados no teste do sistema numa situação real de controle de plantas daninhas ................................................................................. 36

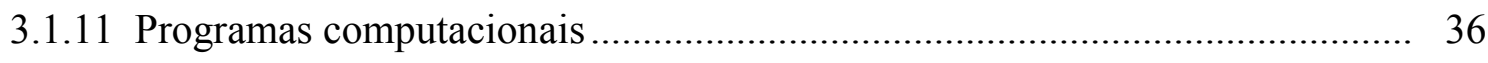

3.1.12 Material utilizado na aplicação do defensivo.............................................. 36

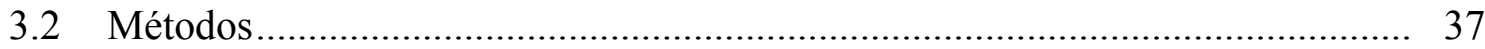

3.2.1 Instalação das válvulas................................................................ 37

3.2.2 Elaboração de um mapa de infestação hipotético........................................ 39

3.2.3 Desenvolvimento do programa computacional para controle do pulverizador.

3.2.3.1 Avaliação das versões em desenvolvimento.............................................. 54

3.2.3.2 Bordadura de segurança para evitar falhas de pulverização nas margens das manchas.................................................................................. 55

3.2.4 Teste do sistema numa situação real de controle........................................ 56

3.2.4.1 Mapeamento das plantas daninhas........................................................... 57

3.2.4.2 Criação do mapa de prescrição .................................................................. 57 
Página

3.2.4.3 Aplicação localizada.......................................................................... 58

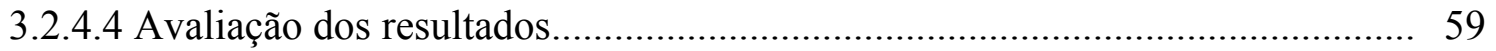

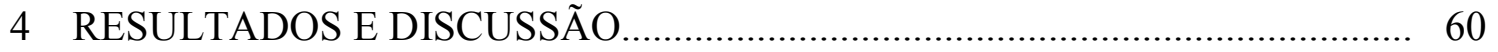

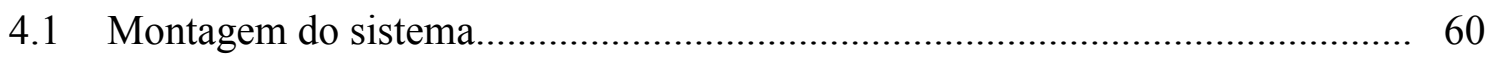

4.2 Desenvolvimento do programa computacional para controle do pulverizador... 60

4.3 Teste do sistema numa situação real de controle ........................................... 64

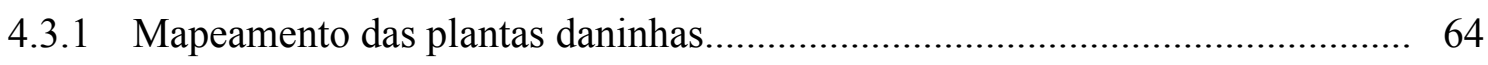

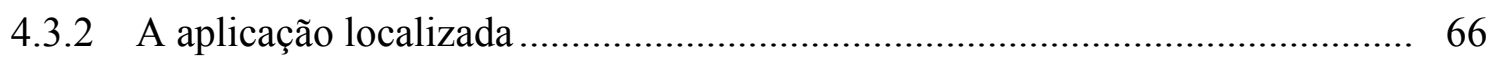

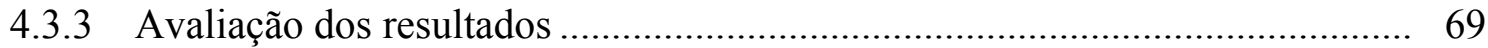

4.3.3.1 Sobreposição do mapa de registro ao mapa de prescrição.............................. 69

4.3.3.2 Identificação visual do controle e mapeamento das manchas não

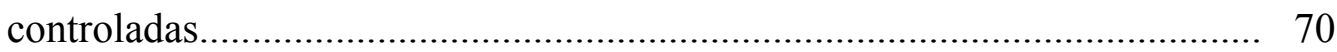

4.3.3.3 Determinação da economia de herbicida................................................ 72

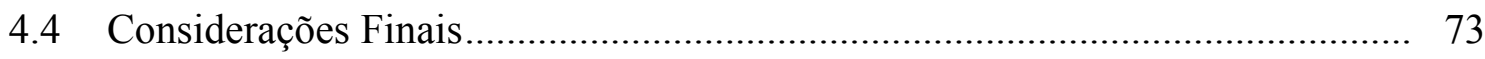

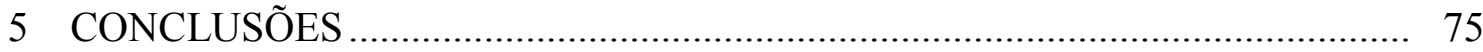

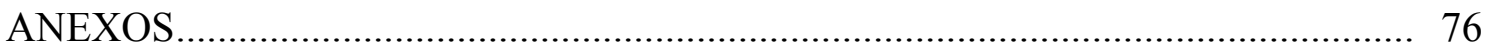

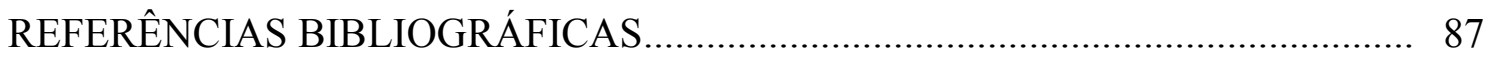




\section{LISTA DE FIGURAS}

Página

1 Princípio de funcionamento dos equipamentos de aplicação em tempo real ........ 16

2 Componentes gerais de um pulverizador de taxas variáveis............................... 25

3 Imagens da área onde foi feita a avaliação do sistema desenvolvido.................. 29

4 Equipamento de GPS com correção diferencial via rádio.................................. 31

5 Esquema de montagem do DGPS........................................................... 32

6 Plataforma para desenvolvimento e avaliação do programa computacional.......... 33

7 Esquema de montagem dos equipamentos utilizados no desenvolvimento do

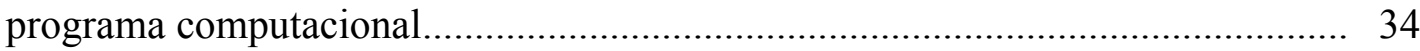

8 Foto da interface de acionamento (A) e seu esquema de funcionamento (B)....... 35

9 Circuito eletrônico da interface de acionamento ............................................. 35

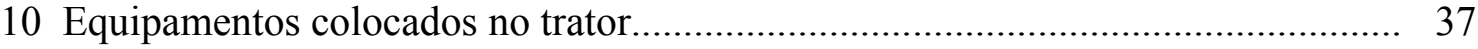

11 Esquema hidráulico do pulverizador e a adaptação realizada .............................. 38

12 Válvulas solenóides instaladas no pulverizador .......................................... 38

13 Mapa de prescrição hipotético ..................................................................... 40

14 Esboço da tela do programa.......................................................................... 42

15 Situação em que o centro do pulverizador se encontra no interior de uma mancha de infestação (A), ou fora de uma mancha, porém com uma (B) ou duas (C) seções sobre manchas distintas .......................................................... 43

16 Possíveis trajetórias e sentidos de deslocamento do trator ................................. 46

17 Trajetória longitudinal do trator, com caminhamento à direita (A) e à esquerda (B) 
Página

18 Trajetória transversal do trator, com caminhamento para cima (A) e para baixo (B).

19 Trajetória inclinada, com caminhamento do trator para cima à direita (A), para cima à esquerda (B), para baixo à esquerda (C) e para baixo à direita (D)

20 Fluxograma do programa computacional 53

21 Percursos realizados na avaliação das versões em desenvolvimento 54

22 Trator entrando numa mancha de infestação................................................... 55

23 Trator saindo de uma mancha de infestação................................................... 56

24 Mapa de registro sobreposto ao mapa de prescrição ......................................... 61

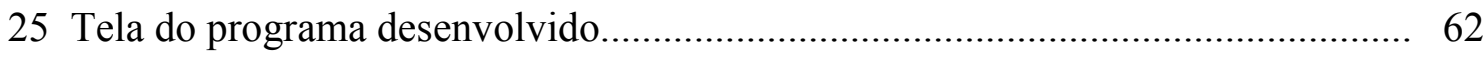

26 Detalhes da tela do programa. Submenus de "Arquivo" (A), submenu de “Configurações” (B), Status das seções e Coordenadas atuais (C) e indicador de erros de recepção e definição do tamanho da barra de pulverização (D).......... 63

27 Os quatro mapeamentos realizados na área experimental ............................... 65

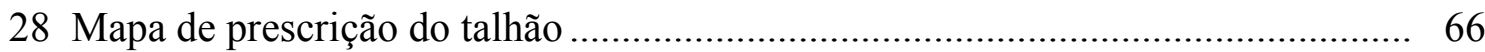

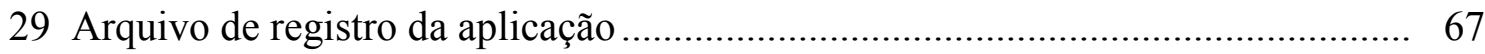

30 Número de pontos onde houve acionamento das seções de barra ........................ 68

31 Porcentagem dos pontos de acionamento das seções de barra ............................. 68

32 Mapa de registro da aplicação sobreposto ao mapa de recomendação.................. 70

33 Manchas de infestação antes (A) e após (B) o controle...................................... 71

34 Falha de aplicação................................................................................... 71 


\section{LISTA DE TABELAS}

Página

1 Fontes de erro e acurácia de posicionamento associadas ao GPS....................... 11

2 Acionamento dos LEDs ao longo dos três percursos.......................................... 61 


\title{
ADAPTAÇÃO DE UM PULVERIZADOR CONVENCIONAL PARA A APLICAÇÃO LOCALIZADA DE DEFENSIVOS AGRÍCOLAS
}

\author{
Autor: JÚLIO CÉSAR DALLA MORA ESQUERDO \\ Orientador: Prof. Titular LUIZ ANTONIO BALASTREIRE
}

\section{RESUMO}

Os defensivos constituem grande parte do custo total dos insumos utilizados na produção agrícola. $\mathrm{O}$ alto consumo de defensivos reduz a lucratividade e aumenta os riscos de contaminação ao ambiente. Uma das alternativas que vêm sendo propostas para a redução da quantidade de defensivos utilizada na produção agrícola é o chamado "gerenciamento localizado das culturas", através do uso dos conceitos da Agricultura de Precisão. Máquinas destinadas à aplicação localizada de defensivos líquidos em doses e produtos variáveis já estão presentes no mercado; entretanto, seu alto custo inicial e alta capacidade operacional inviabilizam sua aquisição em propriedades de menor porte. No presente trabalho, um pulverizador convencional foi adaptado com válvulas solenóides para promover a aplicação do defensivo na estratégia "liga-desliga", utilizando uma dose fixa. Um programa computacional foi desenvolvido para executar o controle independente sobre cada uma das válvulas solenóides presentes nas duas seções de barra do pulverizador, em função das informações de um mapa de prescrição, contendo as coordenadas dos locais onde a aplicação deveria ocorrer. Um DGPS foi conectado ao sistema para informar a localização do trator no campo. O sistema foi submetido a um teste em condições reais de controle de plantas daninhas, as 
quais foram previamente georreferenciadas através do caminhamento do contorno das infestações. Os resultados mostraram que a adaptação realizada, assim como o sistema de controle desenvolvido, permitiram o controle localizado das infestações, resultando na redução da quantidade de herbicida aplicada, em comparação ao tratamento convencional. 


\title{
ADAPTATION OF A CONVENTIONAL SPRAYER FOR SITE-SPECIFIC CHEMICAL APPLICATION
}

\author{
Author: JÚLIO CÉSAR DALLA MORA ESQUERDO \\ Adviser: Prof. LUIZ ANTONIO BALASTREIRE
}

\section{SUMMARY}

Agrochemicals constitute a great part of the total cost of inputs used in the crops production. The high consumption of agrochemicals reduces the profitability and increases the risks of environmental contaminations. One of the alternatives that have been proposed to reduce the amount of chemicals used in the crop production is the site-specific management, using the Precision Agriculture's concepts. Machines used for site-specific application of liquid agrochemicals using variable rates and products are already in the market; however, its high initial cost and operational capacity make its acquisition unfeasible for small farms. In this work, a conventional sprayer was adapted with solenoid valves to allow the site-specific application using the "on/off" strategy, and a fixed rate. A computer program was developed to control each solenoid valve installed at the two sections of the boom, according to the information of a prescription map, containing the position of the points where the application should be done. A DGPS was connected to the system to inform the tractor's position in the field. The system was tested in a real condition of weed control. The perimeter of the weed patches was previously georeferenced. The results showed that the developed system was able to achieve the patch application using fixed rates, resulting in a significant economy of herbicides, when compared with the conventional treatment, over the total area. 


\section{INTRODUÇÃO}

Os defensivos constituem grande parte do custo total dos insumos utilizados na produção agrícola: $56 \%$ no caso da soja, $52 \%$ para o algodão e para o feijão e 35\% para o milho (FNP Consultoria \& Comércio, 2001). Além de reduzir a lucratividade, o alto consumo de defensivos vem causando contaminações ao ambiente, quando estes são utilizados de maneira indiscriminada. As contaminações também atingem os produtos agrícolas, reduzindo sua qualidade e impondo riscos a quem os consome. Esta situação vem provocando pressões da sociedade para que cada vez menos defensivos sejam aplicados nas lavouras, de forma a possibilitar uma agricultura menos poluidora e produtos mais saudáveis.

Uma das alternativas que vêm sendo propostas para a redução do uso dos defensivos é o chamado "gerenciamento localizado das culturas" (Balastreire, 1998), baseado nos conceitos da Agricultura de Precisão. Na agricultura convencional, o conceito da média é levado em consideração na recomendação de um determinado insumo e, desta forma, extensas áreas são gerenciadas de forma idêntica. Entretanto, existe uma variabilidade espacial, e muitas vezes temporal, dos aspectos relacionados à fertilidade, compactação e umidade do solo, plantas daninhas, pragas e doenças, entre outros. Por conseqüência, qualquer recomendação que não considere tais variações pode vir a subestimar ou superestimar as reais necessidades de cada subparcela do campo e, desta forma, aplicações baseadas nessas recomendações podem resultar no fornecimento incorreto dos insumos. Na Agricultura de Precisão, um talhão é visto como algo heterogêneo, apresentando variações ao longo de sua extensão e podendo ser dividido em subparcelas. Os avanços tecnológicos, principalmente das áreas da eletrônica e informática, vieram permitir que estas variações fossem mensuradas, georreferenciadas e 
analisadas. A possibilidade de visitar, georreferenciar e mensurar uma determinada característica de um local do campo, e voltar a tal local com uma acurácia elevada, tem permitido que os conceitos da Agricultura de Precisão sejam postos em prática.

Uma das etapas formadoras do ciclo da Agricultura de Precisão é a aplicação localizada de insumos (Balastreire, 1994), onde ocorre a otimização e a racionalização do uso do insumo propriamente ditas. Máquinas para aplicação localizada de insumos líquidos ou sólidos, munidas de um sistema de posicionamento e de um computador contendo mapas de prescrição, são utilizadas para essa tarefa. Para o caso dos insumos líquidos, existem no mercado máquinas de grande porte, projetadas para a aplicação localizada de defensivos. Contudo, estas máquinas têm um alto custo inicial e grande capacidade operacional, sendo inviável, economicamente, seu uso em propriedades de menor porte. Esta limitação justifica novas pesquisas e o desenvolvimento de equipamentos mais simples, de forma a garantir que os conceitos da Agricultura de Precisão sejam praticáveis em tais propriedades. Além disso, uma das características que elevam o custo destas máquinas é a possibilidade da variação automática da dose e do produto, o que pode, em determinadas circunstâncias, ser substituída pelo simples controle intermitente da aplicação, na estratégia liga-desliga.

O objetivo deste trabalho foi adaptar um pulverizador convencional para a realização da aplicação localizada de defensivos líquidos na estratégia liga-desliga, sem a variação da dose do produto, e avaliar sua eficiência no controle de plantas daninhas numa situação real. Para tanto, modificou-se o esquema hidráulico do pulverizador com o uso de válvulas solenóides, efetuou-se o controle automático da pulverização sem intervenção do operador, desenvolveu-se um programa computacional capaz de controlar as duas seções de barra existentes de forma independente em função das informações contidas num mapa de prescrição, testou-se o sistema numa situação real de controle mapeando as infestações de plantas daninhas existentes e promovendo o controle localizado com o sistema desenvolvido, e verificou-se o controle de plantas daninhas obtido com o sistema desenvolvido.

Embora o objetivo deste trabalho esteja relacionado com a aplicação localizada de defensivos, toda a pesquisa foi dirigida para o uso dos herbicidas. Isto se 
deve ao fato de haver um número reduzido de pesquisas envolvendo o gerenciamento localizado de inseticidas, fungicidas, acaricidas e outros defensivos líquidos. O menor número de pesquisas nesta área está estritamente ligado às dificuldades de mapeamento das pragas e doenças, em função da sua elevada dinâmica espacial e populacional. Muito diferente do que ocorre com as plantas daninhas, onde um elevado número de trabalhos tem mostrado a existência de técnicas de mapeamento da variabilidade espacial das infestações, assim como a potencialidade do uso do gerenciamento localizado, no intuito de reduzir a quantidade de herbicidas aplicada nas lavouras. Mesmo assim, o sistema poderá ser utilizado na aplicação localizada desses outros defensivos, desde que sejam definidas as metodologias de mapeamento de pragas e de doenças, podendo dar origem aos mapas de infestação e de tratamento necessários para o gerenciamento localizado desses fatores. 


\section{REVISÃO DE LITERATURA}

\subsection{As plantas daninhas e o controle químico}

Segundo Alves (2001), as plantas daninhas são espécies vegetais que apresentam uma alta adaptação ecológica e elevada agressividade em relação às plantas cultivadas, podendo, dessa forma, ter uma vantagem competitiva sobre as culturas, caso nenhum controle seja efetuado. A presença das plantas daninhas nas áreas cultivadas resulta na redução da produtividade, tanto pela competição direta pelos fatores de produção, quanto pela interferência sobre as plantas cultivadas.

De acordo com Silva (1983), em ecossistemas agrícolas, a cultura e as plantas daninhas crescem juntas na mesma área e ambas possuem suas demandas por água, luz, nutrientes e dióxido de carbono. Na maioria dos casos, os fatores de produção, ou pelo menos um deles, estão presentes em quantidades não suficientes para assegurar o crescimento e desenvolvimento da cultura. Nestas circunstâncias, relata o autor, qualquer planta daninha que se estabeleça na cultura vai usar parte dos suprimentos dos fatores de crescimento, já limitados, e assim ocorre a competição, reduzindo o rendimento da cultura e a qualidade do produto.

Conforme relata Gelmini (1988), os métodos mais comuns empregados no controle das plantas daninhas são classificados como preventivos, culturais, biológicos, físicos, mecânicos e químicos. O autor relata que, com o desenvolvimento dos herbicidas, o controle químico tornou-se a principal medida de controle das plantas daninhas. Recentes avanços na biotecnologia têm promovido o desenvolvimento de novos princípios ativos, dando origem a produtos mais eficazes no combate às espécies infestantes. 
Segundo Voll (2000), o manejo de plantas daninhas deve ser realizado por meio de medidas integradas de controle, tais como preventivas, culturais, físicas, químicas e biológicas. Segundo o autor, o controle químico é uma das medidas mais eficazes de controle, sendo largamente utilizada na produção agrícola; entretanto, tem sido feito de modo extensivo e, muitas vezes, os níveis de dano econômico não são respeitados, o que resulta na aplicação de doses e quantidades excessivas de defensivos, que acabam atingindo áreas que talvez não necessitassem qualquer tipo de controle. $\mathrm{O}$ autor ressalta que dessa situação decorre a importância de se incorporar no processo de decisão a variabilidade espacial, que pode ser importante no desenvolvimento de uma tática de controle das infestações mais econômica e que cause menores contaminações ao ambiente.

Kolpin et al. (2000) relatam que águas subterrâneas podem conter resíduos não só dos princípios ativos dos herbicidas, como também de complexos químicos oriundos de suas transformações. Neste estudo, os autores verificaram que esses complexos, que em alguns casos podem ser mais tóxicos que os próprios princípios ativos dos herbicidas, são encontrados com bastante freqüência em águas subterrâneas e que, portanto, devem ser considerados nos estudos envolvendo os efeitos dos herbicidas no ambiente.

\subsection{A Agricultura de Precisão}

Christensen et al. (1999) ressaltam que os males causados pelos herbicidas ao ambiente têm estimulado pesquisas para o desenvolvimento de medidas de controle que possam reduzir o uso desses insumos. Uma das alternativas que vêm sendo propostas é o gerenciamento localizado das plantas daninhas, através dos conceitos da Agricultura de Precisão.

Várias são as definições a respeito da Agricultura de Precisão: "um conjunto de técnicas que permite o gerenciamento localizado das culturas" (Balastreire, 1998); "o processo de gerenciamento que considera a variabilidade agronômica" (Blackmore \& Larscheid, 1997); ou ainda "um jogo de ações que tenta reduzir as 
ineficiências na produção agrícola e aumentar o retorno econômico do produtor" (Searcy, 2000).

Goering (1993) relata que, embora as práticas de gerenciamento localizado tenham sido introduzidas somente nesses últimos anos, a filosofia da Agricultura de Precisão foi apresentada ainda no ano de 1929 por C.M. Linsley e F.C. Bauer, os quais dividiram uma área experimental em pequenas subáreas. Para cada subárea os pesquisadores realizaram estudos detalhados, obtendo um mapa da variabilidade espacial da acidez do solo ao longo de toda a área. Suas conclusões foram que as dosagens de calcário deveriam variar ao longo da área, de acordo com a acidez de cada ponto (subárea). Desenvolveram então um mapa de prescrição que indicava a dosagem correta de calcário para cada subárea, prosseguindo com a aplicação manual ponto a ponto. Este é um dos primeiros relatos a respeito da utilização da Agricultura de Precisão. Entretanto, relatam Balastreire et al. (1997), devido a não existência de tecnologia especializada e eficiente capaz de determinar, localizar e quantificar as variações espaciais dos fatores de produção, assim como a inexistência de equipamentos de aplicação localizada e em dosagens variadas de insumos, não havia justificativas agronômicas e econômicas para que fossem identificadas tais variações. Segundo os autores, os recentes avanços tecnológicos nas áreas da eletrônica e informática vieram permitir que os conceitos de Agricultura de Precisão fossem postos em prática.

De acordo com Balastreire (1998), as fases da Agricultura de Precisão podem ser subdivididas em: mapeamento dos atributos do solo e das plantas, mapeamento da produtividade das culturas e aplicação localizada de insumos. Todo este processo é gerenciado pelo chamado SIG - Sistemas de Informação Geográfica. O autor relata que o mapeamento da produtividade pode ser considerado a etapa de menor dificuldade de execução, em função do elevado número de pesquisas e equipamentos disponíveis para tal finalidade.

O mapeamento dos atributos do solo e das plantas engloba o georreferenciamento da fertilidade do solo (Francis \& Schepers, 1997; McBratney \& Pringle, 1997), das infestações de plantas daninhas (Nordmeyer et al., 1997; Heisel et al., 1999), da compactação do solo (Lanças et al., 2000; Silva Junior, 2001), da 
condutividade elétrica do solo (Hartsock, 2000) e das pragas e doenças (Ellsbury et al., 1997; Morgan et al., 2000).

Segundo Balastreire (1994), na aplicação localizada, as quantidades de cada insumo são determinadas em função da análise dos mapeamentos dos atributos do solo e das plantas, do conhecimento agronômico e do histórico da área a ser cultivada. Segundo o autor, a aplicação localizada visa a alocação dos insumos em função dos requisitos específicos do local.

De acordo com Blackmore \& Larscheid (1997), os conceitos da Agricultura de Precisão estão relacionados à variabilidade da produtividade e dos atributos do solo e das plantas. Segundo os autores, existem três tipos de variabilidade: espacial, temporal e preditiva. A variabilidade espacial é observada ao longo do campo e pode ser facilmente constatada em qualquer mapa de produtividade ou fertilidade. A variabilidade temporal é observada quando se comparam mapas de produtividade de vários anos; a variabilidade preditiva é a diferença entre a previsão de algum fator e o que realmente ocorreu. Os autores relatam que, para que se possa gerenciar cada uma dessas variabilidades, é preciso entendê-las e, sobretudo, mensurá-las.

Segundo Dampney \& Moore (1999), os benefícios da Agricultura de Precisão estão relacionados à otimização do uso dos insumos. Disso resulta a diminuição dos custos de produção e a conseqüente redução das contaminações decorrentes da atividade agrícola. Entretanto, Stafford (2001) ressalta que, ainda que os benefícios provenientes do uso dos conceitos da Agricultura de Precisão sejam conhecidos, muitos produtores não têm certeza de que poderão usufruir de tais benefícios se implementarem essa tecnologia em suas fazendas. $\mathrm{O}$ autor relata que isso se deve ao fato dos benefícios econômicos e ambientais da Agricultura de Precisão não terem sido realmente comprovados, exceto para operações de aplicação localizada de herbicidas. Segundo ele, os benefícios econômicos e ambientais advindos do gerenciamento localizado são bastante evidentes, embora tenham sido generalizados em testes de campo e experimentos. Dessa forma, relata o autor, é de extrema importância que sejam feitos avanços, principalmente na área de sensoriamento remoto e de mapeamento da variabilidade. 


\subsection{Os sistemas de posicionamento}

Stafford \& Ambler (1994) relatam que a identificação de atributos espacialmente variáveis e a aplicação localizada e diferenciada de insumos somente podem ser realizadas por meio de um sistema adequado de posicionamento. De acordo com Balastreire (1998), um dos requisitos para se praticar a Agricultura de Precisão é a existência de um sistema de posicionamento que permita a localização geográfica com acurácia em todos os pontos da área a ser trabalhada.

\subsubsection{Sistemas de posicionamento baseados em laser}

Segundo Hague et al. (2000), existe uma variedade de sistemas de posicionamento baseados em laser. O mais simples é o que utiliza três ou mais detectores posicionados ao redor da área de interesse. O sistema a laser é colocado no veículo e realiza uma varredura em um plano horizontal. O tempo que leva para o feixe de luz ser detectado é medido e enviado para o sistema de posicionamento, o qual utiliza triangulação para identificar a localização do veículo. Segundo os autores, este tipo sistema de posicionamento apresenta desvantagens quando utilizado em terrenos excessivamente rugosos ou declivosos, pois qualquer inclinação do veículo pode fazer com que os feixes de luz não atinjam os alvos, a menos que os feixes sejam divergidos verticalmente.

\subsubsection{Sistemas de posicionamento baseados em ondas de rádio}

Ainda segundo Hague et al., os sistemas de posicionamento que utilizam ondas de rádio funcionam de maneira similar aos sistemas baseados em laser. Torres de rádio são instaladas ao redor de uma determinada área, que pode englobar diversas propriedades rurais. Um rádio receptor presente no trator ou qualquer outro veículo agrícola determina a distância entre o veículo e cada uma das torres de rádio. Conhecendo-se essas distâncias, é possível, por triangulação, determinar a posição do 
veículo no campo. Segundo os autores, dependendo-se da altura das torres e da potência dos rádios transmissores, pode-se ter um alcance de até $50 \mathrm{~km}$.

\subsubsection{Sistema de Posicionamento Global (GPS)}

Lechner \& Baumann (2000) descrevem o GPS (Global Positioning System) como um sistema de posicionamento baseado em satélites, criado e operado pelo Departamento de Defesa dos Estados Unidos. Foi posto em utilização no início da década de 80, porém somente em 1995 foi declarado totalmente operacional, ou seja, capaz de determinar posições em qualquer lugar do planeta, 24 horas por dia. Foi inicialmente designado para fins militares; entretanto, atualmente o GPS vem sendo utilizado também na indústria, comércio e agricultura. De acordo com os autores, o GPS é composto por três segmentos: espacial, controle e usuário. O segmento espacial é constituído de uma constelação de 24 satélites distribuídos em seis órbitas a uma altitude de $20.200 \mathrm{~km}$. O segmento de controle é formado por diversas estações de rastreamento espalhadas pelo mundo, cuja função é determinar a órbita exata de cada um dos satélites e atualizar seus sinais de navegação. O segmento do usuário é formado pelo receptor GPS, que converte os sinais vindos dos satélites em informação de posicionamento, velocidade e estimativa de tempo.

De acordo com Ackroyd \& Lorimer (1994), os receptores de GPS calculam a sua posição através de uma técnica que envolve a medição da distância entre a antena do receptor e os satélites rastreados. Ao receberem os sinais dos satélites, os receptores calculam o tempo gasto por cada um dos sinais no percurso entre o satélite e a antena. Para calcular esse tempo, os receptores precisam saber o momento em que o sinal deixa o satélite e o momento em que o sinal alcança a antena. O momento em que o sinal alcança a antena é definido pelo receptor, que possui um relógio interno. Já o momento em que o sinal deixa o satélite é encontrado da seguinte forma: todos os receptores de GPS são sincronizados com os satélites e, portanto, geram o mesmo código digital simultaneamente. Quando o receptor recebe um código do satélite, ele o compara em seu banco de memória e verifica o momento em que o código foi emitido. 
Dessa forma, pode-se saber o momento exato em que o sinal deixou o satélite. A distância entre a antena do receptor e os satélites é determinada multiplicando-se o tempo encontrado pela velocidade dos sinais (velocidade da luz). Segundo os autores, para calcular o posicionamento em termos tridimensionais (latitude, longitude e altitude) são necessárias as distâncias entre a antena do receptor a pelo menos quatro satélites.

\subsubsection{Os erros do GPS}

Segundo Mack (1997), existem diversas fontes de erros capazes de reduzir a acurácia dos cálculos de posicionamento dos receptores de GPS. A maior fonte de erros é a Disponibilidade Seletiva (Selective Availability). O autor define a Disponibilidade Seletiva como um artifício do Departamento de Defesa dos Estados Unidos para a redução da acurácia do GPS pela introdução de erros artificiais de efeméride e de relógio. De acordo com Kennedy (1996), com a Disponibilidade Seletiva ativada existe uma garantia de que em $95 \%$ dos casos a posição calculada pelo receptor esteja no máximo 100 metros distante da posição real da antena. Entretanto, a Disponibilidade Seletiva já não vem mais sendo utilizada desde maio de 2000, resultando em erros menores de posicionamento (OSTP, 2000).

Outras fontes de erro do GPS são destacadas por Leick (1995). Segundo o autor, o tempo de viagem dos sinais de GPS pode ser alterado por efeitos atmosféricos. Ao passarem pela ionosfera e troposfera, os sinais podem ser refratados, alterando sua velocidade. Erros nos dados de efeméride (informações sobre a órbita dos satélites) também podem causar erros no cálculo do posicionamento. Pequenas variações nos relógios atômicos dos satélites podem resultar em erros de posicionamento, já que um erro de um nanosegundo pode dar origem a um erro de posicionamento de 0,3 m. Outra fonte de erro são os ruídos ou distorções do sinal causados por interferências elétricas ou erros inerentes ao próprio receptor. 


\subsubsection{A correção diferencial do GPS (DGPS)}

Ackroyd \& Lorimer (1994) definem a correção diferencial do GPS (DGPS) como uma técnica que visa elevar o nível de performance, acurácia e integridade do GPS. O uso do DGPS pode reduzir consideravelmente os erros de posicionamento, conforme se observa na Tabela 1, adaptada de Mack (1997). O autor relata que a correção diferencial pode ser efetuada pelo uso do uso de sinais de satélites.

Tabela 1. Fontes de erros e acurácia de posicionamento associadas ao GPS (adaptado de Mack, 1997).

\begin{tabular}{lcc}
\hline \multicolumn{1}{c}{ Fontes de Erros } & GPS (m) & DGPS (m) \\
\hline Relógio dos satélites & 1,5 & 0,0 \\
Efeméride & 2,5 & 0,0 \\
Ionosfera & 5,0 & 0,4 \\
Troposfera & 0,5 & 0,2 \\
Ruídos do receptor & 0,3 & 0,3 \\
Multicaminhamento & 0,6 & 0,6 \\
Disponibilidade Seletiva & 30,0 & 0,0 \\
Acurácia de Posicionamento Típica & & 1,0 \\
Horizontal & $60,0(15,0$ sem DS*) & 2,0 \\
Vertical & $80,0(24,0$ sem DS*) & \\
\hline
\end{tabular}

* DS = Disponibilidade Seletiva

Algerbo \& Thylen (1997) relatam que a correção diferencial pode também ser obtida pelo uso de estações base. De acordo com os autores, a estação base (também definida como "estação referência") é um local de coordenadas conhecidas, onde é instalado um GPS e um rádio transmissor. Este tipo de correção diferencial baseia-se no fato de que o erro de posicionamento que ocorre na estação base é simultaneamente idêntico aos erros que ocorrem em receptores de GPS a uma certa distância da base. Entretanto, por estar num ponto de coordenadas conhecidas, a estação base identifica o erro de posicionamento a cada segundo e envia, por meio do rádio transmissor, o sinal de correção aos receptores ao redor da base. 
De acordo com Balastreire \& Baio (2001a), uma outra forma de correção de posicionamento em tempo real são os algoritmos otimizados, já disponíveis no mercado. São programas instalados nos receptores de GPS que calculam a posição correta sem a necessidade de sinais de correção. Os autores concluíram ser viável sua utilização em Agricultura de Precisão, ao compararem este equipamento a um GPS com correção diferencial por meio de sinais de satélite.

\subsection{Variabilidade espacial das plantas daninhas}

De acordo com Nordmeyer et al. (1997) há considerável variabilidade espacial na distribuição das plantas daninhas ao longo das plantações, seja na sua densidade de ocorrência ou no número de espécies. Os autores relatam que, de um lado, essa distribuição desigual pode ser devida a certos aspectos da biologia das plantas daninhas, como a formação de sistemas radiculares perenes. De outro, tal distribuição pode ser influenciada por fatores locais, tais como fertilidade e teor de água do solo, umidade, etc. Segundo os autores, a distribuição desigual de plantas daninhas implica que uma parte do campo pode estar livre delas ou com densidades abaixo do nível de dano econômico. Portanto, confinar as pulverizações às manchas de infestação pode permitir consideráveis economias de herbicida.

Segundo Schwarz et al. (1999), a não homogeneidade da distribuição das plantas daninhas é devida a causas naturais e a interferência do homem. As causas naturais são relacionadas principalmente ao tipo de solo e ao seu suprimento de água. As interferências do homem são relacionadas ao tipo de preparo do solo e ao trânsito de máquinas.

Gerhards et al. (1996) relatam que a população de plântulas de daninhas num campo é espacialmente heterogênea, resultando em manchas agregadas de plantas daninhas com diferentes densidades de infestação e áreas com poucas ou nenhuma planta daninha. Os autores realizaram um estudo sobre a estabilidade espacial de quatro espécies de plantas daninhas ao longo de quatro anos. Seus resultados revelaram uma distribuição de plantas daninhas bastante agregada, com grandes áreas isentas de 
qualquer infestação. Esta distribuição se mostrou estável ao longo dos quatro anos para três das quatro espécies estudadas.

Gerhards at al. (1999), em experimento com aplicação localizada de herbicidas, relataram uma população de plântulas de daninhas extremamente agregada num campo de trigo de 5,1 ha, de forma que em $72 \%$ da área o controle não era justificado.

Green et al. (1997) realizaram o mapeamento de Desmodium tortuosum Swartz em um campo de produção de amendoim de 18 ha e verificaram que, em $70 \%$ da área, não havia a presença das plantas daninhas. Os autores ainda realizaram um outro experimento num campo de 7 ha de amendoim para o controle Panicum texanum Buckley. Seus resultados mostraram que somente em 14\% da área o controle se mostrou justificável.

\subsection{A redução no uso de herbicidas pelo uso da aplicação localizada}

Antuniassi et al. (2000) relatam que a prática da Agricultura de Precisão pode trazer diversos benefícios, englobando aspectos econômicos e ambientais. Segundo os autores, "do ponto de vista econômico, a aplicação localizada permite a priorização do investimento em insumos nas áreas onde o potencial de produção seja mais efetivo, garantindo a possibilidade de maior retorno econômico com menores investimentos". Ainda segundo os autores, "o mesmo pode ser verificado no caso dos tratamentos fitossanitários, pois a aplicação localizada pode significar reduções de mais de $60 \%$ nas quantidades de defensivos utilizados".

Dampney \& Moore (1999), realizando revisão sobre as pesquisas em Agricultura de Precisão, concluíram que fertilizantes nitrogenados e herbicidas são os insumos que melhor podem trazer benefícios econômicos e ambientais se suas aplicações forem gerenciadas localmente.

Mortesen et al. (1995) relataram que, baseados na análise da variabilidade espacial da população de plantas daninhas, a aplicação de herbicidas pós-emergentes pôde ser reduzida em até $71 \%$ para o caso das espécies dicotiledôneas e $94 \%$ para as 
espécies monocotiledôneas. Os resultados mostram que, em determinadas circunstâncias, o gerenciamento localizado de plantas daninhas pode resultar economias de herbicida bastante grandes.

Williams et al. (1999) obtiveram reduções significantes no uso de herbicidas pós-emergentes na cultura do milho, utilizando um modelo algoritmo de decisão, baseado no mapeamento de plantas daninhas. As reduções foram de até 51\% no caso do Rimsulfuron e 11,5\% para Bromoxynil + Terbuthylazine.

Segundo Stafford \& Miller (1996), a quantidade de herbicidas aplicada na produção agrícola pode ser significativamente reduzida se efetuada localmente, ou seja, atingindo apenas as áreas infestadas pelas plantas daninhas, promovendo benefícios econômicos e ambientais. Em experimento realizado com cereais, o tratamento das manchas de infestação de plantas daninhas promoveu uma redução de até $60 \%$ no uso de herbicidas.

Heisel et al. (1996b) desenvolveram um modelo de gerenciamento de aplicação localizada de herbicidas, utilizando uma área de 8 hectares de aveia. Seus resultados mostraram uma economia de herbicida da ordem de 66 a $76 \%$, quando comparada à dose recomendada pelo fabricante.

Nordmeyer et al. (1997) relatam que a aplicação localizada de herbicidas em manchas de infestação de plantas daninhas é uma tentativa de se minimizar a quantidade deste insumo, podendo reduzir os custos de produção e a contaminação do ambiente. Segundo os autores, a aplicação em manchas pode ser feita utilizando-se diferentes herbicidas, ou até nenhum herbicida, de acordo com a distribuição espacial das plantas daninhas e seus respectivos níveis de controle.

Gerhards et al. (1999) obtiveram uma redução de 70\% da quantidade de herbicida em um campo experimental de trigo. Em milho e beterraba, os autores concluíram que em $52 \%$ da área era necessário a utilização da dose total da mistura Bromoxynil + Terbuthylazine, sendo que nos $48 \%$ restantes, meia dose seria o suficiente para o controle total das infestações.

Biller et al. (1997) analisaram a utilização de um sistema optoeletrônico para a detecção e controle instantâneos de plantas daninhas. Suas conclusões foram que 
o sistema foi capaz de promover uma redução de 30 a 70\% (em diversos campos experimentais) da quantidade de herbicidas para realizar o controle, o qual apresentou eficiência de $100 \%$.

Tian et al. (1999), obtiveram reduções entre 48 e 58\% na quantidade de herbicida aplicada em diversos campos experimentais de soja e milho, utilizando um pulverizador capaz de promover a aplicação do defensivo em tempo real.

\subsection{As estratégias de aplicação localizada}

\subsubsection{Aplicação em tempo real}

Segundo Stafford \& Benlloch (1997), a aplicação localizada de herbicidas pode ser feita em tempo real, sem a necessidade do mapeamento das infestações de plantas daninhas. Nesta estratégia, são utilizados pulverizadores especiais munidos de sensores e câmeras que detectam a presença da planta daninha. Suas informações são enviadas a um computador central ou um controlador, que ativa a pulverização somente sobre tais plantas detectadas. A Figura 1 ilustra um esquema típico de detecção e controle das plantas daninhas em tempo real, extraído e adaptado de Vrindts \& De Baerdemaeker (1997).

Antuniassi \& Gadanha Júnior (2000) descrevem duas possibilidades para

a detecção instantânea das plantas daninhas. A primeira tecnologia utiliza sensores óticos que identificam as diferenças na reflexão da luz pelas diversas superfícies encontradas nas áreas agrícolas. A outra opção para a detecção e identificação dos alvos é a análise instantânea de imagens, onde uma câmera de vídeo possibilita a identificação imediata das plantas daninhas, propiciando informações ao sistema de controle do pulverizador sobre sua presença e localização. 


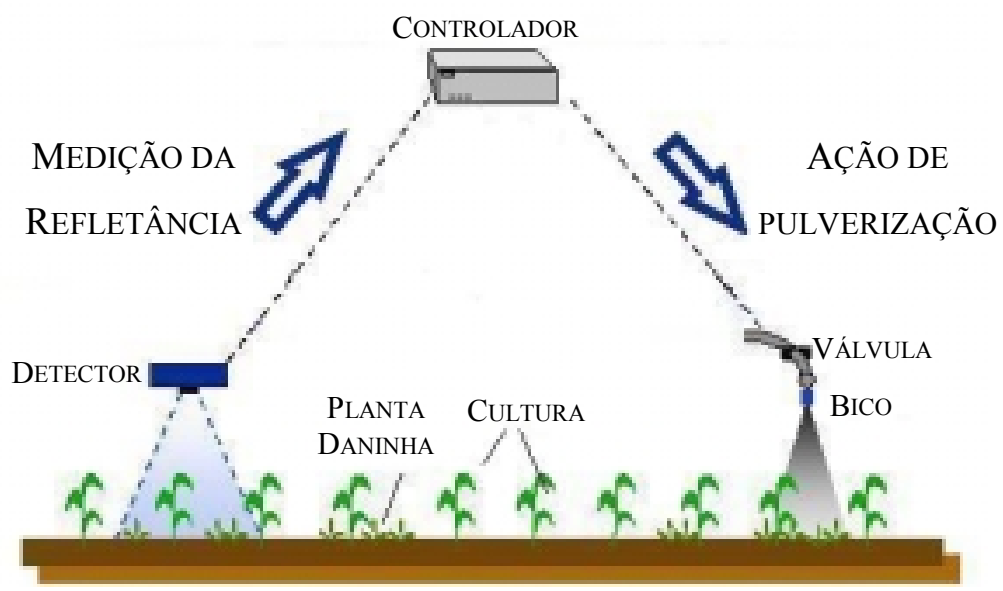

Figura 1 - Princípio de funcionamento dos equipamentos de aplicação em tempo real. Adaptado de Vrindts \& De Baerdemaeker (1997).

Biller et al. (1997), ao desenvolverem uma das primeiras pesquisas envolvendo a aplicação de herbicidas em tempo real, propuseram a utilização de um sistema optoeletrônico para detecção das plantas daninhas nas entrelinhas de cultivo, ou em operações de dessecação para plantio direto. Segundo os autores, as plantas verdes apresentam características de refletância diferentes quando comparadas ao solo, pedras e restos de cultura. Dessa forma, esses sensores são capazes de realizar a diferenciação entre tais materiais.

Heisel \& Christensen (1998) desenvolveram um sistema de detecção de plantas daninhas (WeedEye) através de câmeras digitais munidas de filtros de cor, nos quais somente as cores vermelha e azul, além da luz infravermelha, são capazes de penetrar. Além de detectar sua presença, o sistema possui um computador conectado às câmeras capaz de calcular a área foliar das plantas daninhas. O sistema foi desenvolvido para ser utilizado no controle de plantas daninhas presentes em linhas férreas e funcionou adequadamente. Os autores concluem que o sistema também pode ser utilizado na agricultura, seja na aplicação de herbicidas em tempo real ou como instrumento para a medição de índices de vegetação.

Visando desenvolver equipamentos capazes de realizar a distinção entre planta daninha e cultura, Feyaerts et al. (1998) propuseram um sensor capaz de realizar 
tal função. Sob condições controladas, milho e beterraba puderam ser diferenciados das plantas daninhas com taxas de sucesso de 80 e $90 \%$, respectivamente. De acordo com Scarr et al. (1997), a diferenciação pode ser realizada pelo uso de classificadores ou algoritmos, capazes de analisar as características de refletância, formato e texturas das plantas. Uma tecnologia como essa necessita de um sistema de reconhecimento de imagens combinado a um conjunto de dados sobre as plantas daninhas em diferentes estádios de desenvolvimento.

\subsubsection{Aplicação por mapeamento}

De acordo com Nordmeyer et al. (1997), na aplicação por mapeamento a detecção e o controle da planta daninha são efetuados em momentos diferentes. Inicialmente é gerado um mapa de infestação de plantas daninhas e, em função das informações contidas em tal mapa, o controle é efetuado por meio de máquinas munidas de sistemas de posicionamento e de controle da pulverização. Segundo os autores, os levantamentos necessários para a criação dos mapas de infestação podem ser obtidos de várias formas: amostragens sistemáticas, caminhamento ao redor das infestações, fotografias aéreas, sensoriamento remoto, registros no momento da colheita, uso de dados de anos anteriores e de registros de plantas daninhas durante trabalhos de rotina no campo, das propriedades do solo e da experiência do agricultor. Sensores também podem ser utilizados para o mapeamento de plantas daninhas, desde que atuem em conjunto com sistemas de posicionamento (Vrindts, 1999).

Stafford \& Miller (1996) fazem uma comparação entre a aplicação via mapa e via sensor. Segundo os autores, a aplicação via mapa pode ser mais precisa, uma vez que existe um tempo entre o levantamento das informações no campo e a aplicação, permitindo a análise dos dados obtidos. Além disso, este método permite que exista um processo de tomada de decisão, auxiliando na escolha do herbicida a ser utilizado na área. Christensen et al. (1999) relatam que uma grande vantagem da estratégia de mapeamento é possibilidade de otimizar a escolha do herbicida para o controle da área toda. 


\subsubsection{Mapeamento por amostragem sistemática}

Segundo Heisel et al. (1996a), as plantas daninhas podem ser mapeadas por meio de amostragens. Neste tipo de mapeamento, o campo é subdividido por meio de uma malha ou grade, normalmente com espaçamento eqüidistante e, em cada intersecção da grade, são realizadas amostragens em uma área predefinida pelo amostrador. Segundo os autores, programas computacionais são utilizados para estimar as infestações nas áreas não amostradas, dando origem aos mapas de infestação.

Williams et al. (1998), em experimento com a cultura do milho, realizaram o mapeamento das plântulas de daninhas por meio de amostragens do campo utilizando uma malha de $15 \times 15 \mathrm{~m}$, sendo que em cada ponto de intersecção dessa malha foram contadas as densidades e identificadas as plantas daninhas. Depois do mapeamento realizou-se a interpolação, por triangulação linear, para estimar a densidade de plântulas de daninhas nas áreas não amostradas, obtendo-se, dessa forma, o mapa de infestação da área em estudo.

Wiles \& Schweizer (1999) também utilizaram a amostragem por malha para quantificar não só as plantas daninhas presentes num campo de produção de milho, como também o número de sementes presentes no banco de sementes daquela área. Neste estudo, os autores buscaram desenvolver um modelo matemático para a obtenção do tempo consumido na contagem de plântulas e sementes de daninhas em cada amostra, a fim de se analisar o custo-benefício dessa operação. As variáveis adotadas pelos autores foram o número de espécies, o número total de plântulas, o número de plântulas mono e dicotiledôneas e a porcentagem de areia no solo. Suas conclusões foram que as variáveis que mais interferiram no tempo gasto para a contagem e identificação das plantas daninhas foram o número de espécies, para o caso das plântulas e a porcentagem de areia no solo, para o caso das sementes. Segundo os autores, para tornar viável a obtenção de mapas de infestação de plantas daninhas por meio de amostragens, duas alternativas devem ser estudadas: reduzir o custo do processo e/ou aumentar o valor das informações resultantes desse processo. 
Christensen et al. (1999) realizaram o levantamento das infestações de plantas daninhas num campo de 2,3 ha, de cevada. Utilizaram uma malha de amostragem de 12 × $12 \mathrm{~m}$ e, em cada intersecção dessa malha, realizaram a contagem e a identificação das plantas daninhas numa área de amostragem de $0,25 \mathrm{~m}^{2}$.

Nordmeyer (1997) et al. realizaram amostragens de plantas daninhas em campos de beterraba e cevada. Utilizando uma malha de 30 x $30 \mathrm{~m}$, registraram a densidade de infestação numa área de $0,1 \mathrm{~m}^{2}$. Através de modelos geoestatísticos e interpolações, os autores obtiveram mapas de infestação das áreas estudadas.

Gerhards et al. (1999) utilizaram uma grade de 15 x 7,5 m e uma área amostral de $0,4 \mathrm{~m}^{2}$ para realizar o mapeamento da densidade de plantas daninhas em campos de trigo, cevada, milho e beterraba, obedecendo a quatro níveis de infestação: zero, baixa, média, alta e muito alta. As informações desses levantamentos foram utilizadas no desenvolvimento de mapas de prescrição, para posterior aplicação localizada de herbicidas.

De acordo com Vieira (2000), quando se utilizam técnicas de amostragem de algum atributo, seja ele fertilidade do solo, infestação de plantas daninhas ou incidência de doenças e pragas, os conceitos de geoestatística devem ser empregados. Segundo o autor, quando existe dependência espacial de um determinado atributo, a geoestatística pode ser utilizada para estimar valores dos atributos em estudo para os locais não amostrados, sem tendeciosidade e com variância mínima, por meio de processos de interpolação, tais como krigagem, co-krigagem, inverso da distância, triangulação, entre outros.

\subsubsection{Caminhamento ao redor das infestações}

De acordo com Colliver et al. (1996), os mapas de infestação de plantas daninhas podem ser gerados por meio do georreferenciamento do perímetro das infestações. $\mathrm{Na}$ busca de um método ideal, os autores analisaram esta e mais duas metodologias de mapeamento: amostragem sistemática e registros no momento da colheita. Seus resultados mostraram que o método do georreferenciamento do perímetro 
foi o mais eficiente e resultou num mapa onde $66,5 \%$ da área total estava infestada. Os métodos de amostragem e de registro no momento da colheita deram origem a mapas com 68,6 e $90 \%$ de infestação, respectivamente. O mapeamento pode incluir todas as manchas existentes na área e dar origem a um único mapa de infestação, como fizeram os autores, ou pode, ainda, contemplar pesos ou conceitos para cada mancha em função da densidade de plantas daninhas, como fizeram Rew et al. (1996), dando origem a diferentes mapas.

Balastreire \& Baio (2001b) utilizaram esta metodologia para a criação de mapas de infestação numa área de produção de soja de 72 ha, em pousio. Um quadriciclo, um DGPS e um computador portátil foram utilizados para georreferenciar manchas com três níveis de infestação: zero ou muito baixa, média e alta. Os resultados permitiram concluir que, para a situação encontrada, a metodologia avaliada mostrou-se adequada e os mapas de infestação resultantes podem servir de suporte ao desenvolvimento de mapas de prescrição, para posterior aplicação localizada de herbicidas.

Stafford et al. (1996) relatam o desenvolvimento de um sistema de aquisição de dados portátil para ser utilizado em mapeamentos. Um programa computacional foi desenvolvido e um Palmtop foi integrado a um GPS. O sistema apresenta a opção de caminhamento ao redor das manchas ou simplesmente a escolha de uma forma circular ou retangular para uma determinada infestação, quando não é possível o caminhamento ao redor dela. Cada região demarcada pode receber uma nota, de acordo com a densidade de infestação. Testes de campo mostraram que o sistema desenvolvido apresentou grande potencialidade de utilização e facilidade de aprendizagem por parte dos produtores.

\subsubsection{Análise de imagens e sensoriamento remoto}

Lippert \& Wolak (1999) utilizaram fotos aéreas para mapear a espécie Senna obtusifolia na cultura do milho. As fotos foram obtidas com um filtro infravermelho no momento em que a cultura apresentava folhas marrons, já próxima ao 
ponto de colheita. Neste estádio de desenvolvimento, a planta daninha estudada apresentava cor verde e pleno desenvolvimento vegetativo. Nestas condições, os autores puderam diferenciar as manchas de infestação e georreferenciá-las. O mapa resultante foi comparado a um mapeamento realizado um ano antes, onde as manchas de Senna obtusifolia foram georreferenciadas por caminhamento com o GPS. Os resultados mostraram que os mapeamentos foram coincidentes, o que evidencia a potencialidade do uso de fotografias áreas para o mapeamento de plantas daninhas. Entretanto, os autores ressaltam que o sucesso dos resultados foram influenciados pela situação encontrada, onde a cultura e a planta daninha apresentavam características totalmente distintas em termos de coloração, o que nem sempre é possível verificar.

Stafford \& Benlloch (1997) relatam que a obtenção manual das informações necessárias para a elaboração de mapas de infestação exige um trabalho intensivo e acaba dependendo muito da subjetividade dos operadores. Os autores discutem técnicas automáticas de detecção e armazenamento das informações das plantas daninhas. Para tanto, realizaram um experimento utilizando imagens aéreas obtidas em duas escalas: imagens tomadas por um aeromodelo controlado por controle remoto e equipado com câmeras de vídeo e fotografia, tendo um campo de visão de 300 x 500 m e resolução espacial de 0,5 a 1 m; e imagens tomadas próximas ao solo, também com câmeras de vídeo e fotografia, sendo que as imagens representavam amostras de $0,25 \mathrm{~m}^{2}$. As imagens foram analisadas por um programa de computador, o qual realizou tentativas de diferenciar plantas daninhas e plantas cultivadas, levando-se em consideração aspectos como cor e forma das plantas. Suas conclusões foram que a detecção das plantas daninhas utilizando-se dos métodos descritos é bastante difícil, devido a similaridade da refletância espectral entre plantas daninhas e plantas cultivadas. Entretanto, as duas técnicas estudadas foram capazes de realizar essa diferenciação entre algumas plantas daninhas e plantas cultivadas, o que mostra que podem ser utilizadas como processos complementares aos processos manuais, podendo ter seus níveis de classificação aumentados.

Christensen et al. (1999), visando obter uma técnica de mapeamento mais racional, propuseram a análise de fotografias para a medição das densidades de 
infestação de plantas daninhas. Para testar esta técnica, um levantamento por amostragem foi realizado e em cada ponto amostrado foi obtida uma foto com uma máquina fotográfica convencional apoiada num tripé com uma altura padrão, de forma a proporcionar o mesmo ângulo de visão do amostrador. As fotos foram digitalizadas e processadas, obtendo-se, posteriormente, a área relativa das plantas daninhas em cada foto. De posse das densidades de infestação (obtidas pelo levantamento) e da área relativa das plantas daninhas (obtida pelas fotos), os autores utilizaram softwares baseados em GIS para a obtenção de mapas de estimativa da distribuição de plantas daninhas ao longo de toda a área de estudo. Comparando-se o mapa obtido através das imagens com o mapa por amostragem, os autores concluíram que a área foliar das plantas daninhas foi capaz de proporcionar uma boa medição da densidade de infestação.

\subsubsection{Utilização de dados históricos}

Segundo Walter et al. (1997), mapas de infestação de plantas daninhas de diferentes anos podem ser correlacionados. Wilson \& Brain (1991) relatam que durante um período de dez anos uma espécie de gramínea (Alopecurus myosuroides) cresceu em manchas bem definidas em um campo comercial de cereais. As manchas eram bastante estáveis e houve pouca evidência da formação de novas manchas sob controle convencional.

Gerhards et al. (1996) concluíram que durante um período de quatro anos algumas espécies estudadas de dicotiledôneas mostraram pouca habilidade de colonizar novas áreas em campos comerciais de soja e milho, recebendo tratamento efetivo com herbicida ao longo de vários anos. Ressaltam que futuras investigações devem ser conduzidas em outras áreas de produção, sob diferentes sistemas de produção e com outras espécies de plantas daninhas, de modo a obter um maior entendimento da extensão da estabilidade espacial das manchas de infestação.

Williams (1999) avaliaram a variabilidade espacial e temporal das principais plantas daninhas das culturas de milho e beterraba. Os autores concluíram que as infestações de gramíneas persistiram de um ano para outro. Áreas com moderada e 
alta densidades de gramíneas mapeadas, no ano de 1998, coincidiram com os mapeamentos de um ano antes.

Nordmeyer \& Dunker (1999) encontraram significantes correlações entre a densidade de algumas espécies de plantas daninhas e propriedades do solo. Assim, os autores relatam que propriedades do solo podem ser correlacionadas com mapas de infestação de plantas daninhas de anos anteriores para indicar locais de maior probabilidade de ocorrência das infestações.

\subsubsection{Uso de algoritmos de decisão para a criação de mapas de prescrição}

De acordo com Heisel (1997), algoritmos de decisão são programas computacionais que auxiliam na recomendação de uma dose ótima do herbicida. Segundo os autores, esses algoritmos realizam a integração de uma série de informações, tais como: efeitos da competição entre uma determinada cultura e suas principais plantas daninhas, densidade de infestação, nível de dano econômico, eficiência do herbicida, entre outras. Os modelos calculam a perda potencial de produtividade em função da densidade de infestação e do nível de competitividade das espécies. Os autores utilizaram o DAPS (Decision Algorithm for Patch Spraying) para a construção de um mapa de prescrição num campo de cevada, onde realizaram a aplicação em manchas. Seus resultados mostraram uma redução de $41 \%$ da quantidade de herbicida em relação ao tratamento em área total, sem que houvesse redução da produtividade ou alta infestação no momento da colheita. Heisel et al. (1999) obtiveram redução de herbicida de $54 \%$ utilizando o mesmo modelo.

Clay et al. (1999) utilizaram um modelo bio-econômico denominado GWM (General Weed Management Model) e concluíram que sua utilização para a geração de mapas de prescrição pode reduzir a quantidade total de herbicidas aplicada na agricultura. 


\subsection{Equipamentos para aplicação localizada de defensivos agrícolas}

De acordo com Antuniassi et al. (2000), a aplicação localizada de defensivos pode ser realizada variando-se tanto a dose do defensivo quanto o volume de calda aplicado. Os sistemas mais simples realizam o controle da aplicação numa estratégia liga-desliga, onde a dose e o volume de calda são mantidos constantes nas partes do campo onde a aplicação é efetuada.

Williams et al. (1998) realizaram a aplicação localizada de herbicidas sobre manchas de infestação utilizando o sistema liga-desliga. Assim, a aplicação foi feita somente nas áreas onde a densidade de plântulas de daninhas era maior que o nível de dano econômico.

Antuniassi et al. (2000) relatam que variações na dose podem ser obtidas por mudanças do volume aplicado, mantendo-se a concentração constante, ou através de variações na concentração do defensivo na calda, ao longo da pulverização. Este último método de variação da dose é utilizado nos pulverizadores mais avançados. O princípio básico destes sistemas está relacionado ao armazenamento do defensivo e do diluente em recipientes separados, realizando-se a mistura somente no momento da aplicação, através da injeção do defensivo na tubulação que leva a calda aos bicos.

Clark \& McGuckin (1996) descrevem um equipamento para a aplicação localizada de insumos líquidos em taxas variáveis, o qual é baseado no esquema da Figura 2. Um sensor de velocidade (radar) informa a velocidade real de deslocamento do veículo ao computador/controlador, uma vez que este é um fator que influi na taxa de aplicação dos insumos. Outros fatores que influem na taxa de aplicação são a largura da barra, o volume de calda aplicado e a dose desejada. O mapa de prescrição, carregado no computador, informa os locais onde a pulverização deve ocorrer e suas respectivas dosagens. O pulverizador utiliza um sistema de injeção, o que permite que o operador não mais necessite realizar a mistura dos produtos químicos no tanque principal. Esses produtos ficam num depósito, de onde vão ser bombeados (de acordo com a necessidade, conforme o mapa de prescrição) para o injetor, sendo então misturados com a água, armazenada num tanque à parte. A bomba de injeção realiza o controle preciso 
da taxa de injeção do defensivo para promover sua correta concentração. A taxa de fluxo do líquido que vai para as barras de pulverização é controlada pela válvula de fluxo, a qual é aberta ou fechada pelo computador/controlador. O fluxo do líquido é monitorado por um sensor, e as informações geradas por ele são utilizadas pelo controlador para os ajustes mais finos da válvula de controle de fluxo. A taxa de fluxo dos líquidos e a posição do veículo são continuamente gravadas no computador para registro histórico. Segundo os autores, além da dosagem, esses equipamentos podem também variar os produtos aplicados.

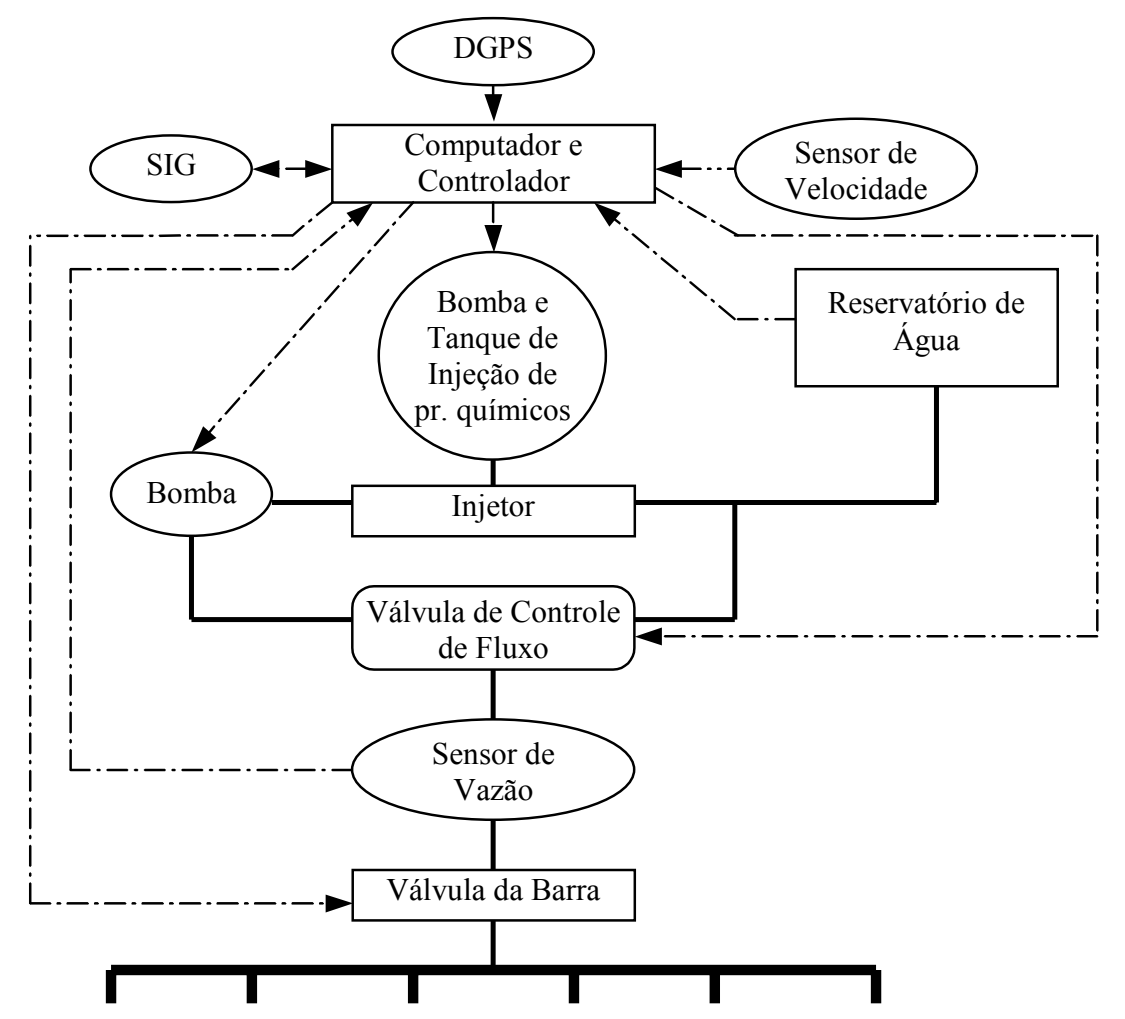

Figura 2 - Componentes gerais de um pulverizador de taxas variáveis (Adaptado de Clark \& McGuckin, 1996).

Balastreire \& Baio (2001c) discutem a aplicação localizada de defensivos em taxas variáveis. Os autores utilizaram um pulverizador automotriz para realizar a aplicação localizada de herbicidas numa área de 9,8 ha, previamente mapeada. Sobre o pulverizador foi instalado um sistema de injeção direta de defensivos composto por 
bombas peristálticas, motores elétricos, válvulas, sensores de pressão e vazão, reservatórios para os produtos químicos, um sistema eletrônico microprocessado como controlador central, além de uma interface eletrônica para conexão a um computador portátil, munido de um programa para gerenciamento da aplicação localizada, em função do mapa de prescrição. Os autores obtiveram uma redução de 31,6\% de herbicida, em comparação ao tratamento convencional. Entretanto, os autores relatam que este tipo de equipamento possui alto tempo de resposta, o qual deve ser levado em consideração para o adequado controle de plantas daninhas.

Paice et al. (1995) desenvolveram um pulverizador experimental para a investigação dos efeitos da aplicação variável de herbicidas. Um pulverizador convencional de barras $(12 \mathrm{~m})$ tratorizado serviu como base de desenvolvimento e seu esquema hidráulico foi modificado, ficando composto, basicamente, por um tanque central de água, uma bomba de diafragma, um regulador de pressão e dois sistemas de injeção de defensivos. Os bicos foram montados em duas seções da barra, cada uma delas recebendo os defensivos dos sistemas de injeção de forma separada. Os bicos foram reunidos em grupos de quatro e o fluxo da água misturada ao defensivo foi controlado por meio de válvulas solenóides. Esta disposição permitiu a aplicação simultânea de dois produtos distintos e a transição rápida entre dois níveis de dose. Um computador central, contendo o mapa de prescrição e conectado a um sistema de posicionamento, controlava um sistema eletrônico, que por sua vez atuava sobre os sistemas de injeção. Testes com o pulverizador mostraram um alto tempo de resposta e desta forma os autores concluíram serem necessários mais estudos para a redução deste tempo. O controle das válvulas solenóides sobre os bicos permitiu maior resolução do pulverizador, variação espacial da dose e maior potencial de economia de herbicidas.

Paice et al. (1996) descrevem outras alternativas mais simples para a realização da aplicação localizada de defensivos:

$\Rightarrow$ Sistemas de controle da pressão: promovem a variação da dose por meio da variação da pressão nos bicos. Inicialmente foram utilizados em pulverizadores que atuam com taxas fixas, em conjunto com dispositivos de medição da velocidade, 
para a correção da dose em função da variação da velocidade. Podem ser utilizados em sistemas de aplicação localizada para a variação da dose.

$\Rightarrow$ Válvulas solenóides: dispositivos relativamente baratos que podem atuar no controle de seções de barra ou de bicos individuais. Apresentam rápida resposta e contribuem no aumento da resolução espacial do pulverizador. Apresentam a desvantagem de permitir apenas dois níveis de dose (total ou nula).

$\Rightarrow$ Bicos de fluxo duplo: neste tipo de bico, o líquido e o ar são misturados juntos. Controlando as pressões do líquido e do ar, pode-se variar o fluxo do líquido que é pulverizado.

Stafford \& Miller (1993) descrevem a utilização de um sistema para aplicação localizada de defensivos agrícolas composto de uma barra de $12 \mathrm{~m}$ dividida em seções de $2 \mathrm{~m}$, cada uma controlada de forma independente por meio de válvulas solenóides. Três concentrações do defensivo podiam ser aplicadas, sendo variadas por meio de um controlador; ou ainda dois produtos podiam ser aplicados em cada uma das linhas paralelas. O controle do sistema era realizado por meio de dois microcomputadores e um GPS foi utilizado para determinar a localização do pulverizador no campo. Um mapa de prescrição foi utilizado para informar os locais de aplicação e as dosagens. O sistema mostrou ser capaz de alocar o defensivo de forma acurada, com menos de $1 \%$ de erro.

Gerhards et al. (1999) descrevem a utilização de um pulverizador experimental composto por uma barra de $15 \mathrm{~m}$ dividida em cinco seções de $3 \mathrm{~m}$. Cada uma das seções era controlada, individualmente, por válvulas solenóides, conectadas a uma unidade de controle. Três diferentes doses podiam ser aplicadas através da mudança da pressão do sistema, por meio de uma válvula reguladora de pressão adaptada ao circuito hidráulico do pulverizador. O sistema de controle da pulverização era ligado a um computador portátil, onde um mapa de tratamento era carregado e um DGPS conectado. Os autores realizaram testes controlando a barra toda $(15 \mathrm{~m})$ e cada uma das cinco seções de forma independente. Os dois testes foram conduzidos num campo de trigo, onde $72 \%$ da área apresentava infestações abaixo do nível de dano econômico. No primeiro teste utilizando o controle sobre a barra toda quando uma parte dela entrava 
numa mancha, $46 \%$ do campo foi pulverizado. No segundo teste, controlando as cinco seções, $30 \%$ da área foi pulverizada. Os autores concluíram que o controle de um maior número de seções aumentou a resolução espacial do pulverizador e permitiu maior redução da quantidade de herbicida aplicada.

Tian et al. (1999) desenvolveram e testaram um sistema capaz de detectar a densidade e o tamanho de plantas daninhas em tempo real no campo. O objetivo dos autores foi integrar um sistema de identificação a um pulverizador automático, de forma a dar origem a um sistema de sensoriamento e de pulverização inteligentes. Ao invés de utilizar imagens de alta resolução e reconhecimento individual de plantas daninhas, o sistema de detecção utilizou imagens de baixa resolução e algoritmos de processamento instantâneo de imagens, capazes de realizar a diferenciação entre plantas daninhas e algumas culturas. Foi utilizado somente um controle liga/desliga em cada um dos bicos, mantendo-se constante a vazão. Os resultados mostraram que o sistema foi capaz de detectar zonas de solo exposto, zonas de plantas daninhas e zonas de cultura numa resolução de 3,7 x 0,43 m e decidir sobre a pulverização em $0,37 \mathrm{~s}$. 


\section{MATERIAL E MÉTODOS}

\subsection{Material}

\subsubsection{Local}

O sistema para a aplicação localizada de defensivos agrícolas foi desenvolvido no Laboratório de Instrumentação Agrícola do Departamento de Engenharia Rural da ESALQ/USP. A avaliação do sistema numa situação real de controle de plantas daninhas ocorreu numa área de 4,1 ha pertencente à Usina Costa Pinto, localizada no município de Piracicaba. Essa área, cujas coordenadas aproximadas são $22^{\circ} 36^{\prime} 34^{\prime \prime}$ S e $47^{\circ} 38^{\prime} 08^{\prime}$ 'W, é mostrada pelas imagens da Figura 3.
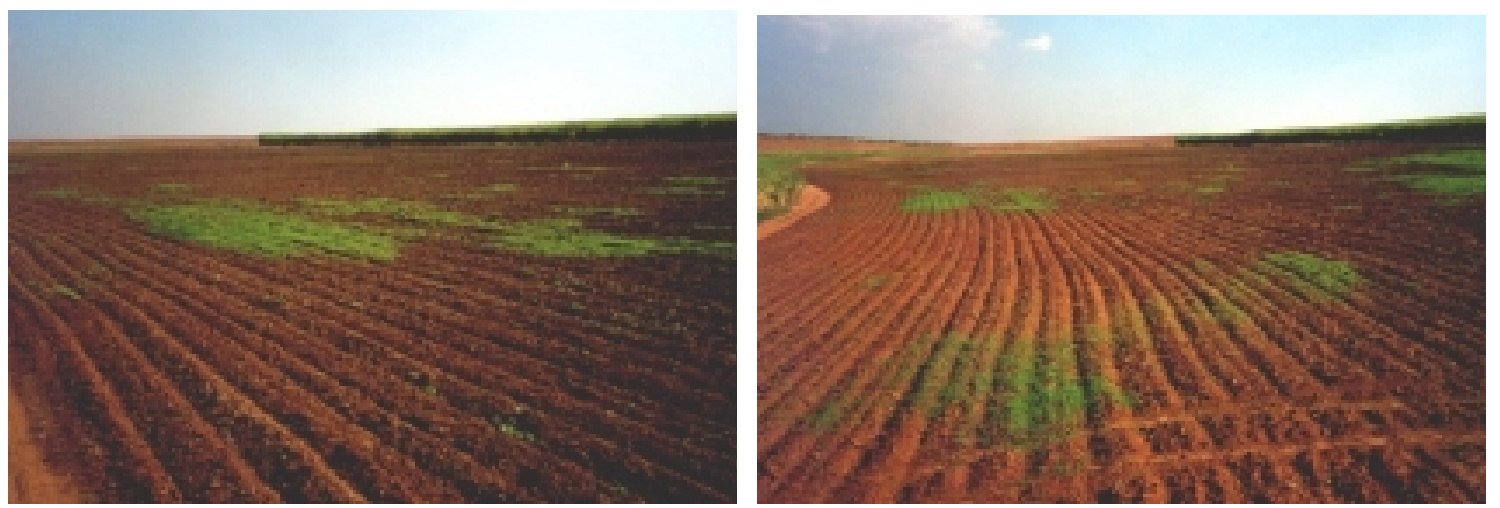

Figura 3 - Imagens da área onde foi feita a avaliação do sistema desenvolvido. 


\subsubsection{Trator}

O trator utilizado foi o Modelo MF 5285, com tração 4x2 e potência de $62,5 \mathrm{~kW}(2.200 \mathrm{rpm})$ no motor.

\subsubsection{Pulverizador}

Tratorizado, de barras, da marca Jacto, modelo PJ-401, cujas principais características técnicas são:

- Tanque de polietileno com capacidade para $400 \mathrm{~L}$;

- Agitação hidráulica da calda;

- Bomba modelo JP-402, com capacidade de recalque de $38 \mathrm{~L} /$ minuto e pressão máxima de $2100 \mathrm{kPa}\left(300\right.$ lbf.pol $\left.{ }^{-2}\right)$;

- Barra de 9,5 m, com duas seções e acionamento manual;

- Dimensões (largura, altura e comprimento): 1,10 x 3,20 x 1,35 m;

- Peso: 1912,3 N (vazio);

- Bicos tipo leque, série UF - 02/50;

- Válvulas antigotejo

\subsubsection{Válvulas solenóides}

Duas válvulas solenóides da marca Jefferson, modelo 1335BA6, com as seguintes características técnicas:

- Faixa de pressão de trabalho: 10 a 1000 kPa;

- Normalmente fechadas;

- Conexão de 3/4" BSP, adaptadas com redutor para 1/2"”;

- Tensão 12 V;

- Construídas com material não corrosivo. 


\subsubsection{Sistema de posicionamento}

Equipamento de GPS da marca Ashtech com correção diferencial via rádio, composto pelos seguintes itens (os números à frente de cada item correspondem à sua posição na foto da Figura 4):

- Monitor AgNavigator (1);

- Receptor GPS Ashtech (2);

- Rádio transmissor Pacific Crest RFM96S (3);

- Rádio receptor Pacific CrestRFM96W (4);

- Duas antenas receptoras de sinais GPS (5);

- Antena de rádio para transmissão do sinal de correção (6);

- Antena de rádio para recepção do sinal de correção (7);

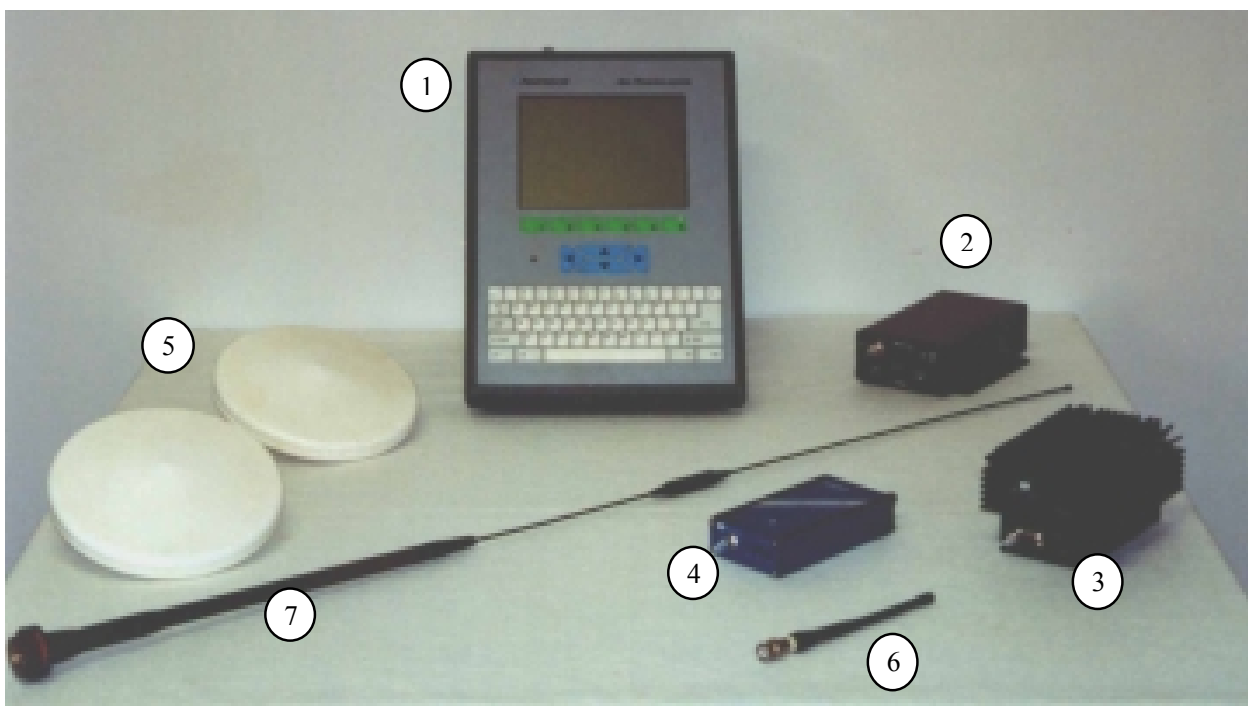

Figura 4 - Equipamento de GPS com correção diferencial via rádio.

$\mathrm{O}$ esquema de montagem dos equipamentos encontra-se na Figura 5. O DGPS é formado por uma estação base (colocada num ponto fixo, de coordenadas conhecidas) e por um ponto móvel. A base é constituída pelos itens: receptor GPS, rádio transmissor, antena receptora dos sinais de GPS, antena transmissora dos sinais de correção e bateria $12 \mathrm{~V}$. A base é montada de forma que sua antena transmissora dos 
sinais de correção mantenha contato visual com a antena receptora, presente no ponto móvel. O ponto móvel é composto pelos itens: monitor AgNavigator (que possui um receptor de GPS interno), rádio receptor, duas antenas receptoras dos sinais de correção e dos sinais de GPS e bateria 12V. O monitor AgNavigator possui uma saída serial de comunicação (COM2) para exportação de dados de posicionamento para monitores de colheita, computadores portáteis, etc.
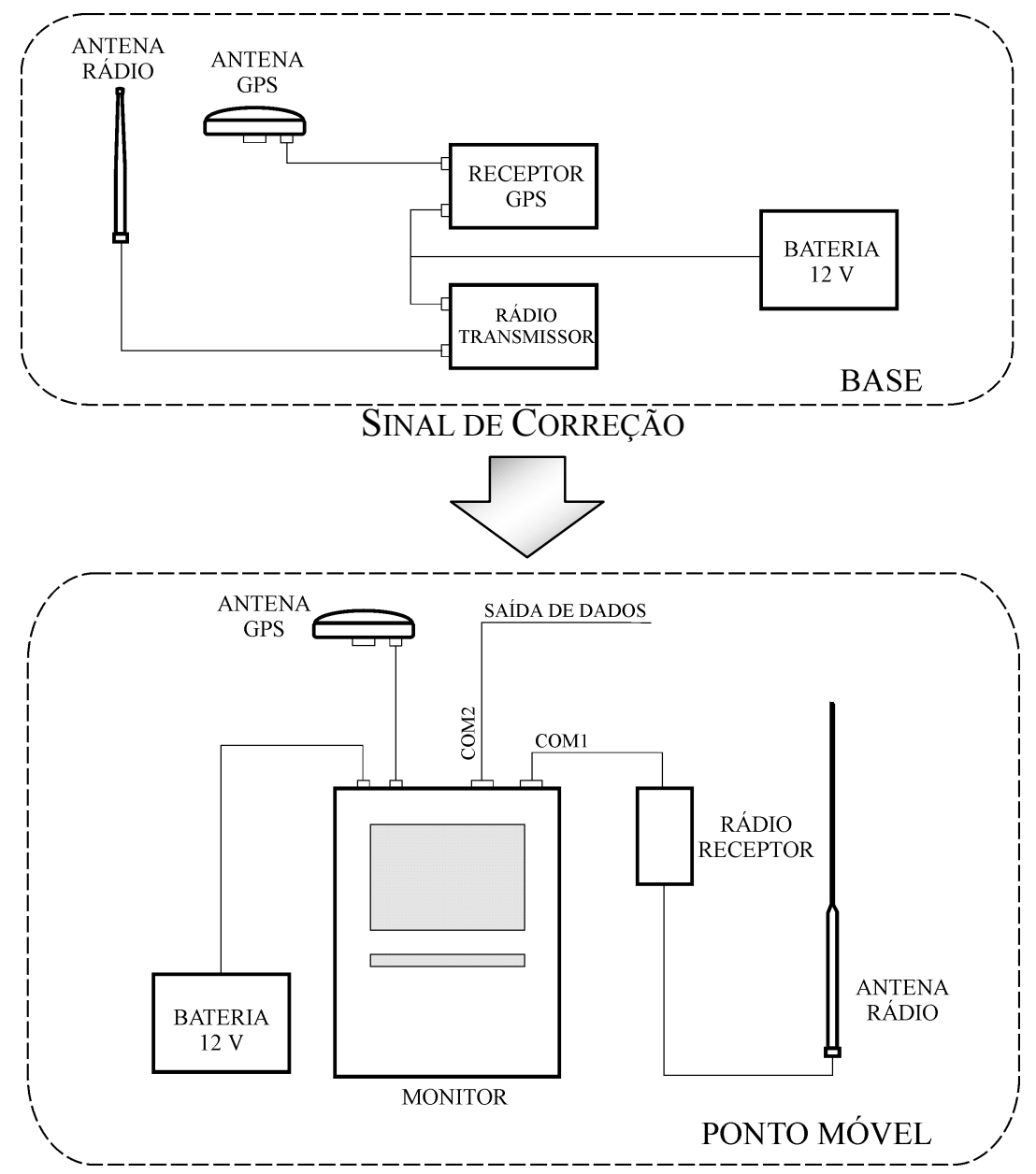

Figura 5 - Esquema de montagem do DGPS.

\subsubsection{Computadores}

- Computador Desktop da marca Ritron, com processador Pentium 233 MHz.

- Computador Notebook da marca Rocky, com processador Pentium $166 \mathrm{MHz}$. 
- Computador Palmtop da marca Compaq, com processador de $206 \mathrm{MHz}$.

\subsubsection{Equipamentos utilizados no desenvolvimento e avaliação do programa}

Ao longo do desenvolvimento e avaliação do programa computacional, optou-se pelo uso de uma plataforma montada no engate de três pontos do trator (Figura 6) e dois diodos emissores de luz (LEDs), em substituição ao pulverizador e as válvulas solenóides, respectivamente.

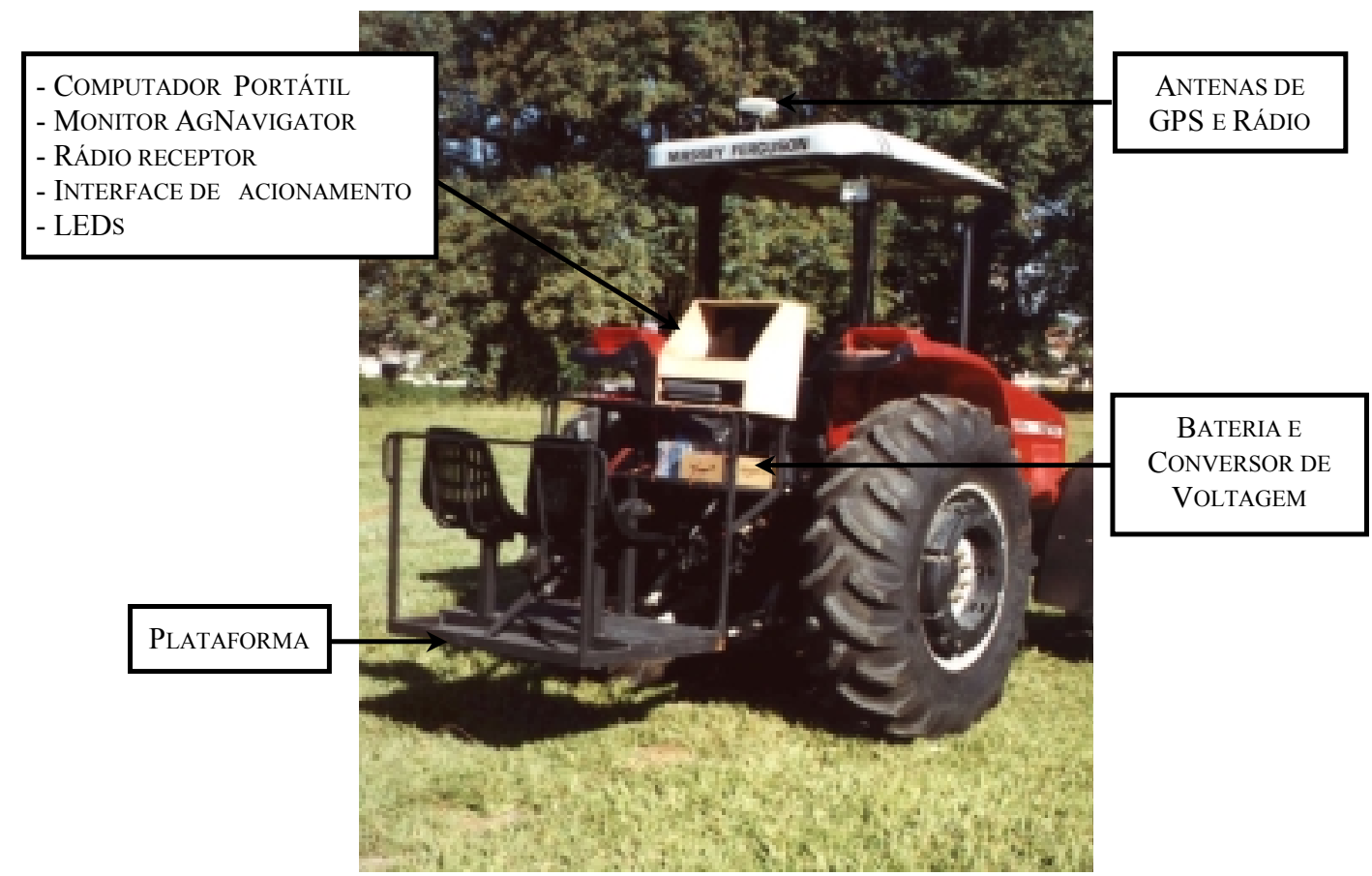

Figura 6 - Plataforma para desenvolvimento e avaliação do programa computacional.

$\mathrm{O}$ esquema de montagem dos equipamentos utilizados no desenvolvimento e avaliação do programa computacional é mostrado na Figura 7. O sistema de posicionamento, descrito no item 3.1.5, foi conectado ao Notebook, onde as versões do programa em desenvolvimento foram carregadas. Devido ao baixo tempo de duração da bateria do computador, utilizou-se um conversor de voltagem para elevar a tensão da bateria de 12 para $127 \mathrm{~V}$. Uma interface de acionamento, a ser descrita no item 
3.1.8, foi conectada à porta paralela de comunicação do Notebook. Os dois LEDs e uma bateria 12V Sunrise, modelo LC-R12751, foram interligados à interface.

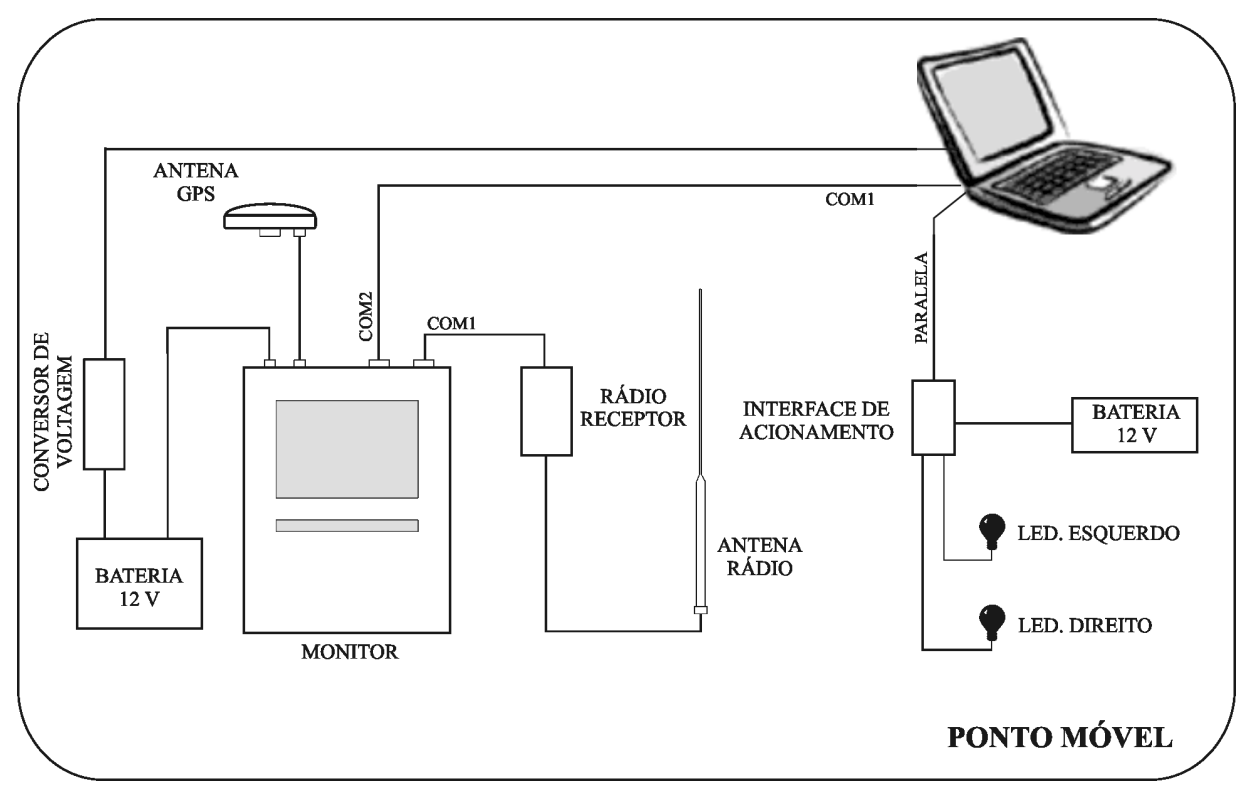

Figura 7 - Esquema de montagem dos equipamentos utilizados no desenvolvimento do programa computacional.

\subsubsection{Interface de acionamento}

Para que o acionamento das válvulas solenóides pudesse ser feito por meio de um computador, foi necessário o desenvolvimento de uma interface (driver) de acionamento optoeletrônico, cuja função foi fornecer tensão elétrica às válvulas de acordo com os comandos do computador, transmitidos por meio de impulsos elétricos. $\mathrm{O}$ acionamento dos LEDs esquerdo e direito (simulando a presença das válvulas) é feito quando o computador envia nível alto de tensão $(5 \mathrm{~V})$ aos pinos 2 e 3 , respectivamente, da porta paralela de comunicação. Ao receber estes impulsos, a interface fecha o contato entre a bateria e as válvulas solenóides. A Figura 8A mostra a foto da interface desenvolvida e a Figura 8B seu esquema de funcionamento. O circuito eletrônico da interface é mostrado pela Figura 9. 


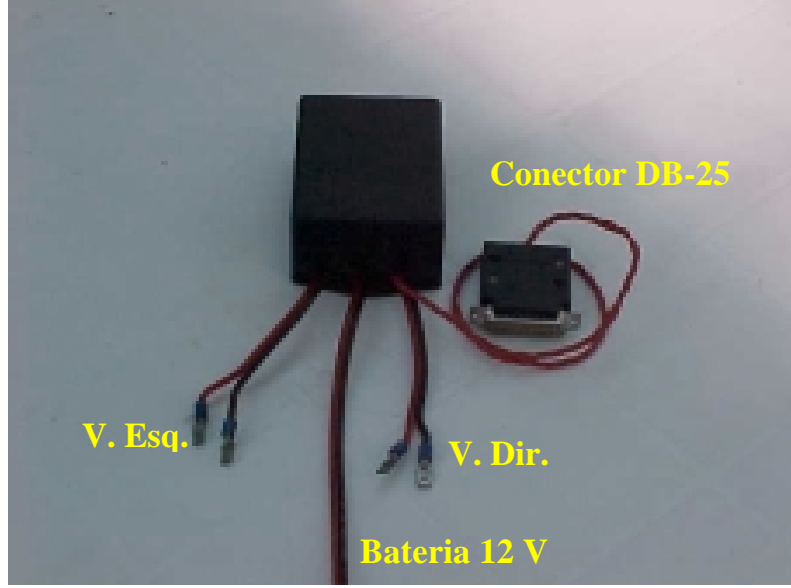

(A)

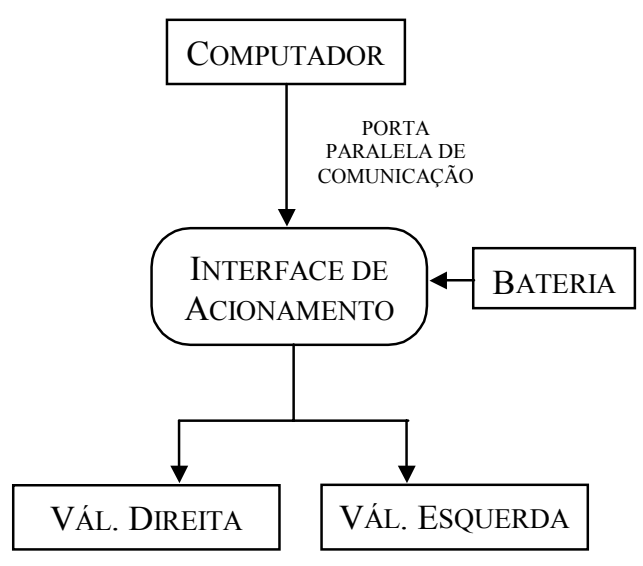

(B)

Figura 8 - Foto da interface de acionamento (A) e seu esquema de funcionamento (B).
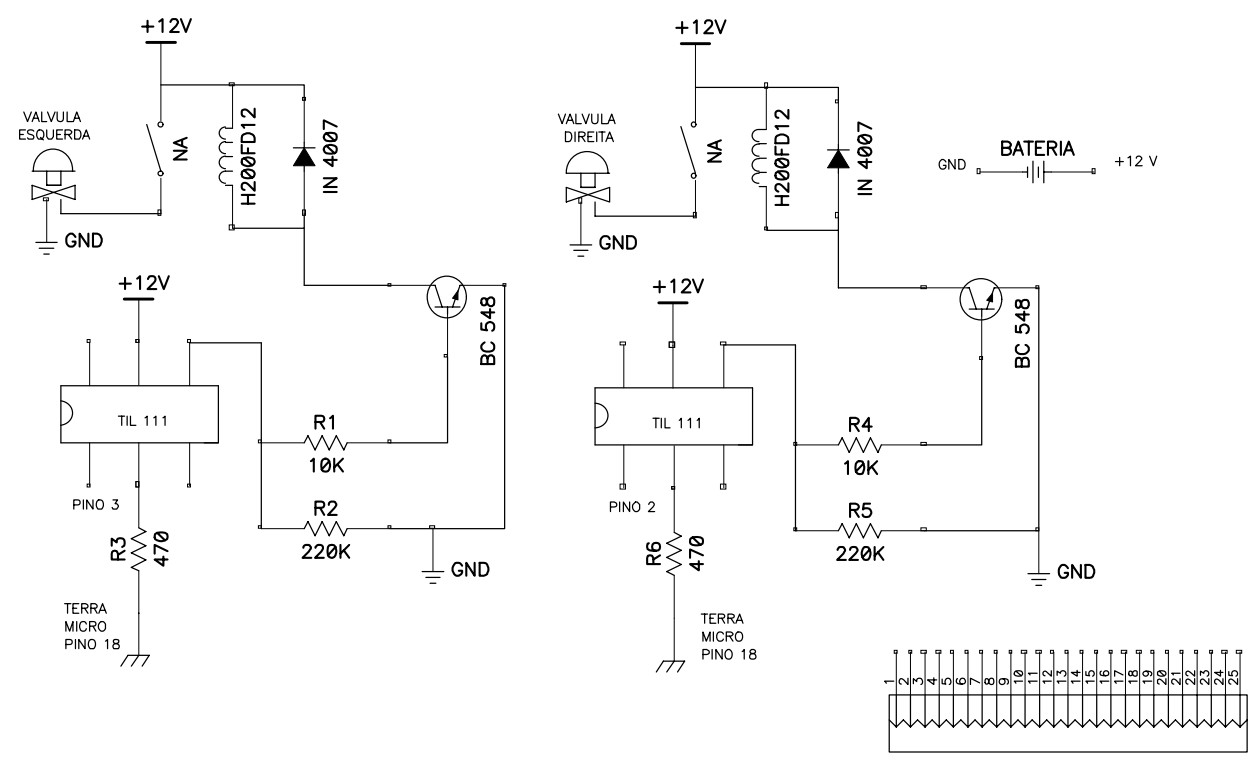

CONECTOR DB-25

Figura 9 - Circuito eletrônico da interface de acionamento.

\subsubsection{Equipamentos utilizados no mapeamento das plantas daninhas}

No mapeamento das plantas daninhas, para o teste do sistema desenvolvido numa situação real de controle, utilizou-se do Palmtop, o qual foi conectado ao DGPS descrito no item 3.1.5. O monitor AgNavigator, o rádio receptor e 
uma bateria foram acomodados numa mochila. As antenas de recepção dos sinais de GPS e de correção foram adaptadas a uma haste de metal. Desta forma, os mapeamentos puderam ser feitos a pé. Um tripé foi utilizado para a montagem da base.

\subsubsection{Equipamentos utilizados no teste do sistema numa situação real de controle de plantas daninhas}

Para o teste do sistema numa situação real de controle de plantas daninhas

utilizou-se os mesmos equipamentos descritos no item 3.1.7. Entretanto, ao invés da plataforma e dos LEDs, utilizou-se o pulverizador (descrito no item 3.1.3) e as válvulas solenóides (item 3.1.4).

Para a acomodação dos equipamentos (monitor AgNavigator, interface de acionamento, rádio, Notebook e cabos) foram construídas duas caixas de madeira, montadas sobre uma estrutura de metal presa à carroceria do trator. A foto da Figura 10 mostra a caixa e os equipamentos montados sobre o trator, no ângulo de visão do operador. A bateria e o conversor de voltagem foram colocados no assoalho do trator.

\subsubsection{Programas computacionais}

- Planilha eletrônica Excel;

- Linguagem de programação Borland $\mathrm{C}^{++}$Builder, versão 1.0;

- Programa de Sistema de Informação Geográfica (SIG) SSToolBox, versão 3.2.0;

- Field Rover II, versão 7.11.

\subsubsection{Material utilizado na aplicação do defensivo}

- Glyphosate (RoundUp);

- Equipamentos de proteção individual (EPI). 


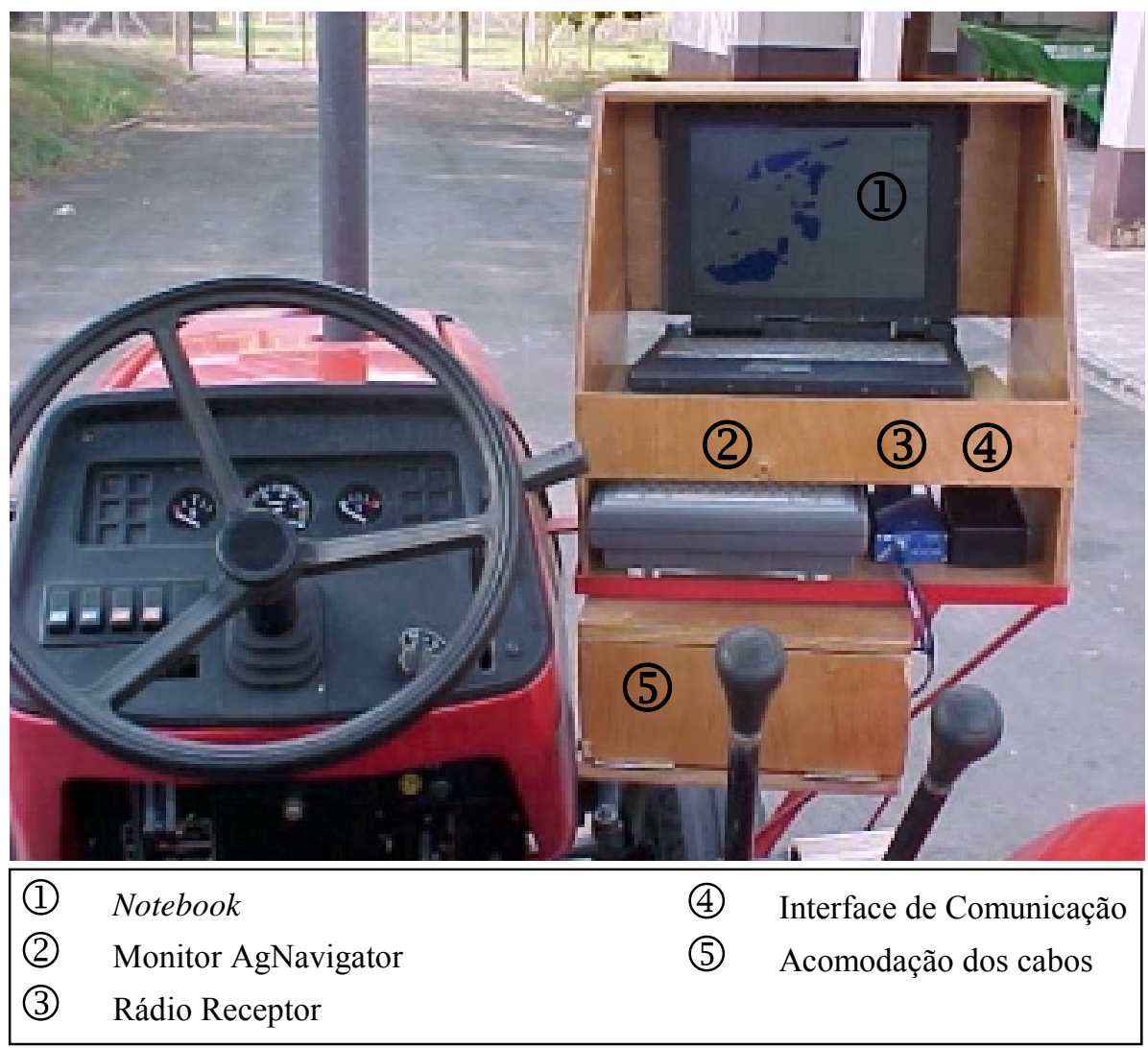

Figura 10 - Equipamentos colocados no trator.

\subsection{Métodos}

\subsubsection{Instalação das válvulas}

O pulverizador utilizado possui uma barra dividida em duas seções. A adaptação realizada constituiu-se da instalação de uma válvula solenóide em cada uma das seções do pulverizador. As válvulas foram adaptadas às mangueiras que levam a calda de pulverização às barras, interrompendo o fluxo do líquido. Para que o controle da pulverização fosse dependente somente da abertura das válvulas solenóides, o registro para as seções do pulverizador foi mantido sempre na posição aberto para ambas seções. Desta forma, a calda somente seguia em direção à barra de pulverização quando as válvulas solenóides eram acionadas, caso contrário a calda voltava ao tanque pela 
mangueira de retorno. A Figura 11 mostra os esquemas original e modificado do pulverizador. A foto da Figura 12 mostra as duas válvulas solenóides instaladas e fixadas na estrutura de metal do pulverizador através de braçadeiras.

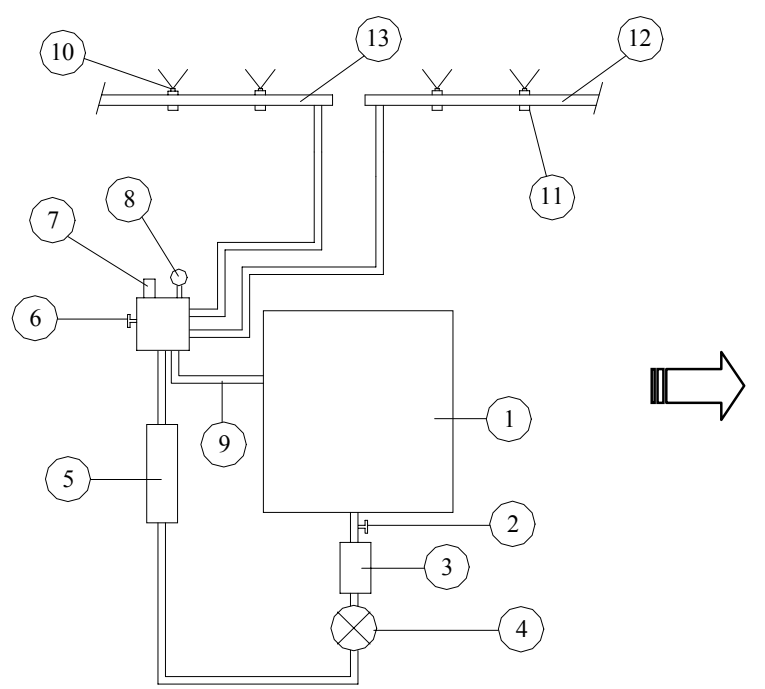

ORIGINAL

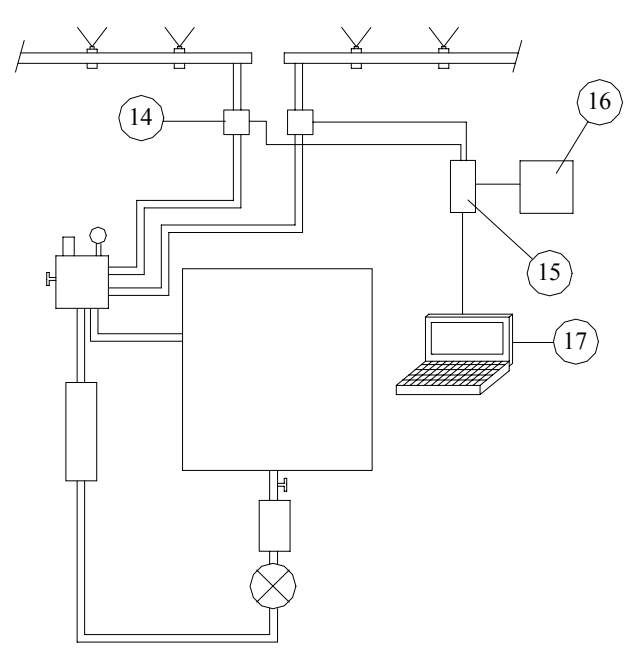

MODIFICADO

13) Seção esquerda da barra

14) Válvula solenóide

15) Interface de acionamento

16) Bateria

17) Notebook
7) Regulador de pressão

8) Manômetro

9) Retorno

10) Bicos

11) Válvula anti-gotejo

12) Seção direita da barra

5) Câmara de compressão

6) Registro para as seções

Figura 11 - Esquema hidráulico do pulverizador e a adaptação realizada.

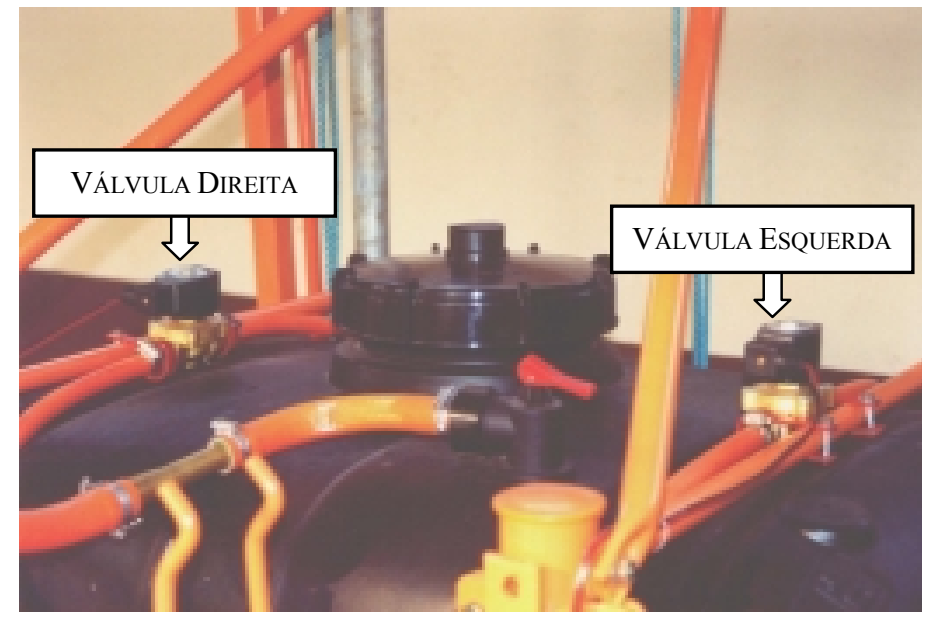

Figura 12 - Válvulas solenóides instaladas no pulverizador. 


\subsubsection{Elaboração de um mapa de infestação hipotético}

Para que o programa computacional pudesse ser desenvolvido, houve a necessidade da elaboração de um mapa de prescrição, uma vez que as informações contidas no arquivo de prescrição constituem o ponto de partida do programa. Assim, utilizou-se de uma área gramada sobre a qual uma região retangular de 10 x 15 m foi demarcada com o auxílio de estacas, representando uma mancha de infestação hipotética. Uma fita amarela foi posta em torno do perímetro desta região, rente ao solo, para a melhor visualização de seus limites.

Para a criação do mapa foram utilizados os equipamentos descritos no item 3.1.9. Os mapeamentos foram iniciados após o carregamento do programa Field Rover II no Palmtop. O primeiro deles visou o georreferenciamento dos limites do gramado, realizado por meio de caminhamento ao redor de seu perímetro. O segundo ocorreu sobre a fita amarela. Os dois arquivos gerados foram transferidos ao computador Desktop e carregados no programa SSToolBox, onde foi realizada a sobreposição dos dois mapas gerados e a definição de duas regiões de controle: a primeira, formada pelo retângulo mapeado, onde a pulverização deveria ocorrer; e a segunda, formada pelas áreas restantes do campo, onde o controle não deveria ser efetuado. A Figura 13 mostra o mapa de prescrição hipotético gerado no programa SSToolBox.

O passo seguinte foi a exportação do mapa de prescrição para um arquivo, tendo sido escolhido o formato Mid-Tech, com extensão $\operatorname{arx}$. Neste formato, são listados grupos de coordenadas referentes ao perímetro de cada uma das regiões do mapa de prescrição. Todas as coordenadas são apresentadas no formato UTM (Universal Transverse Mercator), que é um sistema de coordenadas planas, em unidade métrica. $\mathrm{O}$ arquivo gerado está listado no Anexo A.. 


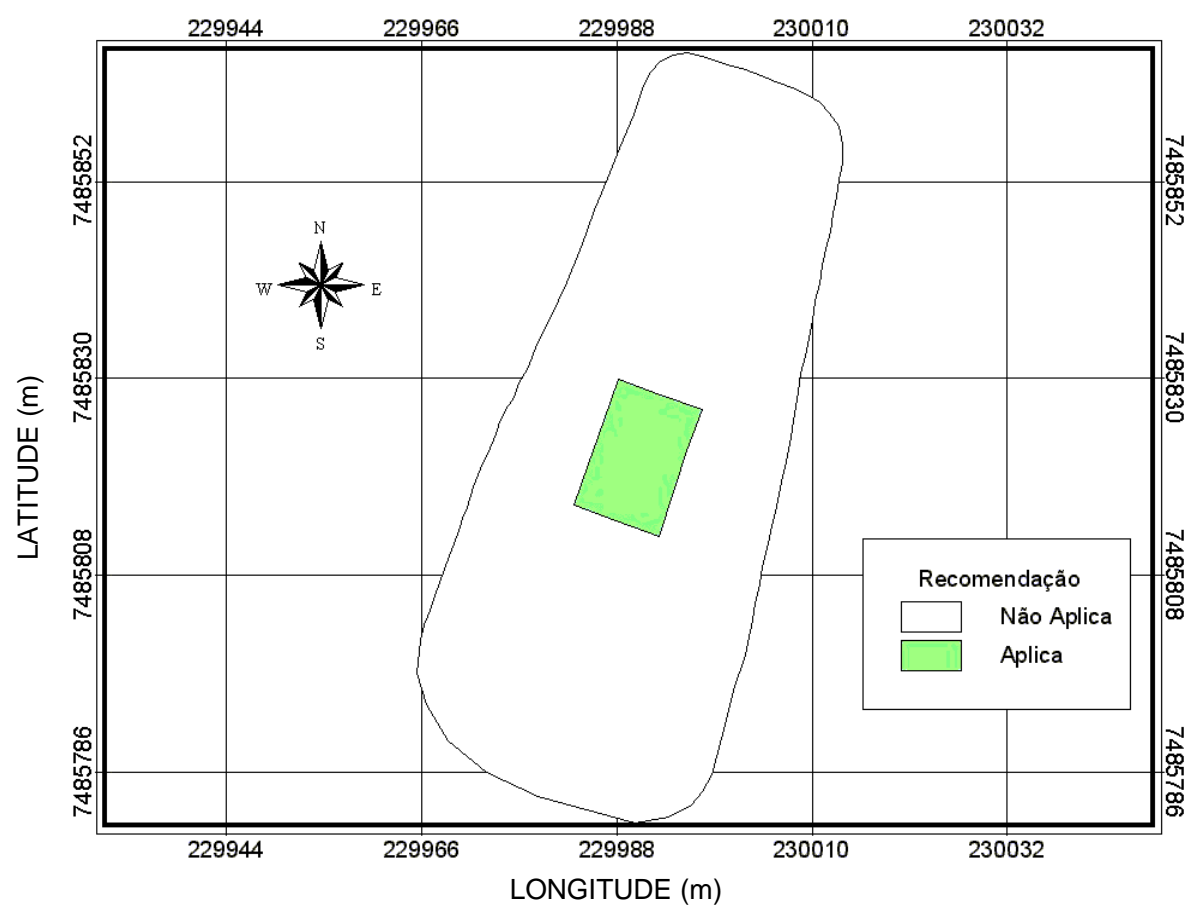

Figura 13 - Mapa de prescrição hipotético

\subsubsection{Desenvolvimento do programa computacional para controle do pulverizador}

O programa computacional tem a função de acionar as válvulas solenóides presentes nas seções do pulverizador nos locais definidos pelo mapa de prescrição, promovendo a aplicação do defensivo somente nas manchas de infestação. São necessárias duas informações para seu funcionamento: o mapa de prescrição, contendo as coordenadas dos limites das infestações mapeadas, e a posição do pulverizador no campo, fornecida em tempo real pelo DGPS.

O programa foi desenvolvido para controlar as duas seções de barra existentes no pulverizador, de forma independente, através do acionamento das válvulas solenóides presentes em cada uma delas. Portanto, as quatro possibilidades de acionamento das válvulas são: ambas abertas, ambas fechadas, somente direita aberta e somente esquerda aberta. 
O desenvolvimento de um programa como este se justificou pela ausência de programas computacionais no mercado, capazes de controlar um pulverizador levando em consideração mais de uma seção em sua barra de pulverização.

O programa foi criado em linguagem $\mathrm{C}^{++}$, através do aplicativo Borland

$\mathrm{C}^{++}$Builder, versão 1.0. Foi desenvolvido para ser executado sob a plataforma Windows, o que permitiu a possibilidade de se empregar a interface gráfica para a tomada de todas as decisões do programa. Optou-se por dividir a tela do programa em três regiões: menu, área de informações e plano gráfico, contendo o mapa. As etapas de desenvolvimento do programa são descritas a seguir.

\section{a) Carregamento do arquivo de prescrição}

Uma rotina de extração de dados foi desenvolvida para o carregamento de arquivos com extensão arx (listado no Anexo A), gerados conforme relatado no item 3.2.2. As coordenadas são extraídas do arquivo de prescrição, sendo descartados os cabeçalhos de cada um dos grupos de coordenadas.

\section{b) Impressão do mapa de prescrição no plano gráfico}

Por possuírem o formato UTM, as coordenadas do arquivo de prescrição podem ser representadas num eixo cartesiano, numa projeção plana. Para serem impressas no plano gráfico, as coordenadas são convertidas em unidades de pixel, sendo utilizado um parâmetro de conversão que considera as maiores e menores latitudes e longitudes extraídas do arquivo de prescrição. O ponto de origem deste eixo encontra-se no canto superior esquerdo do plano gráfico, sendo que as coordenadas em $\mathrm{X}$ aumentam para direita e as de Y para baixo. A Figura 14 mostra um esboço da tela do programa.

Todos os grupos de dados contidos no arquivo de prescrição são impressos no plano gráfico, sendo que o grupo referente aos limites do campo recebe a cor preta. Os grupos referentes às manchas de infestação recebem a cor azul, e as regiões formadas por estes pontos são preenchidas pela mesma cor. 


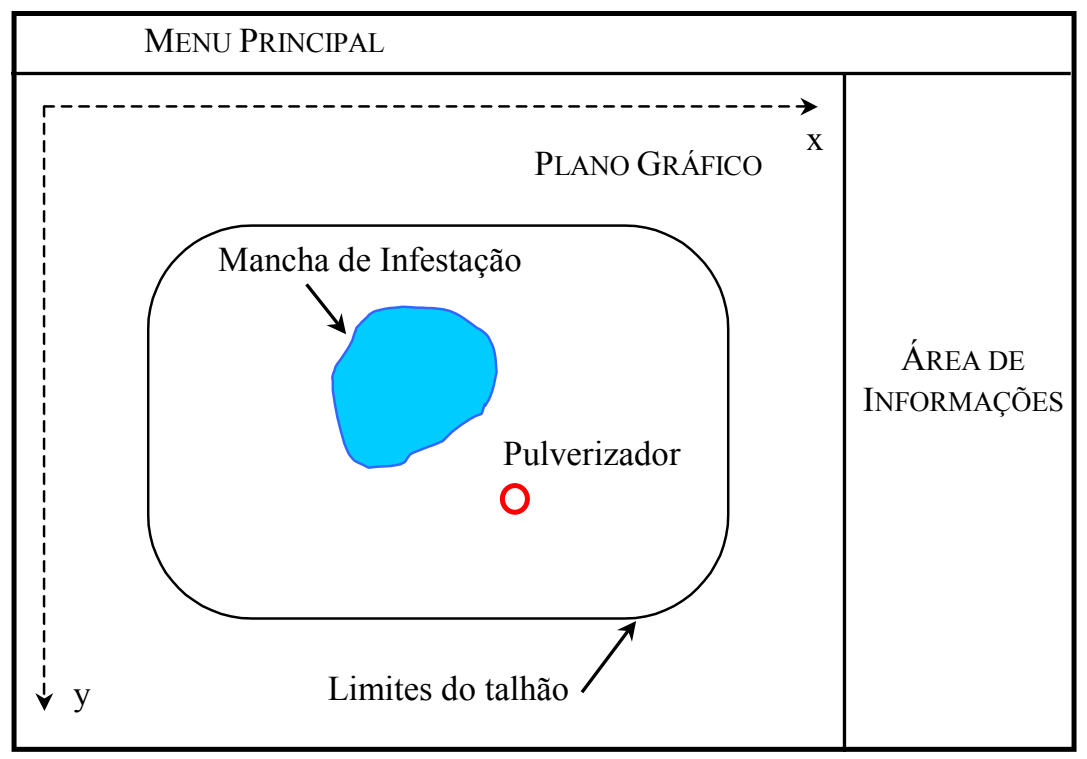

Figura 14 - Esboço da tela do programa.

c) Impressão da posição do pulverizador no plano gráfico

O DGPS, conectado à porta serial do computador envia, a cada segundo, um pacote de informações, dentro do qual estão contidas as latitudes e longitudes da posição do pulverizador no campo. Uma rotina de extração separa os valores referentes às coordenadas no formato geodésico, em graus, minutos e décimos de minutos. Para serem impressas no plano gráfico, essas coordenadas são transformadas para o formato de coordenadas planas (UTM). A transformação é feita por meio de um algoritmo, fornecido por Molina \& Sá (2000) ${ }^{\square}$ De posse das coordenadas do pulverizador numa projeção plana, as latitudes e longitudes são convertidas em termos de pixel para que o ponto seja impresso no plano gráfico. Este ponto é representado por um círculo vermelho, como mostrado na Figura 14.

Quando ocorre um erro de recepção dos sinais do GPS ou dos sinais de correção e nenhuma posição é enviada, o programa considera o último ponto enviado pelo DGPS.

${ }^{1}$ MOLINA, E.C.; SÁ, N.C. Algoritmo para transformação entre coordenadas geodésicas e UTM. Comunicação pessoal. Instituto Astronômico e Geofísico da Universidade de São Paulo, 2000. 


\section{d) Verificação do posicionamento do pulverizador em relação às manchas}

Para verificar se o pulverizador encontra-se no interior de uma mancha de infestação, o programa verifica a cor do pixel onde o centro do círculo vermelho foi alocado na tela. Se este pixel for da cor azul, significa que o centro do pulverizador se encontra no interior de uma mancha. Esta situação é mostrada na Figura 15A, onde pode-se visualizar uma fração do plano gráfico do programa. A figura do trator com o pulverizador foi utilizada apenas para a melhor visualização da situação e a região mais escura é uma mancha de infestação. Neste caso, ambas seções do pulverizador são acionadas.

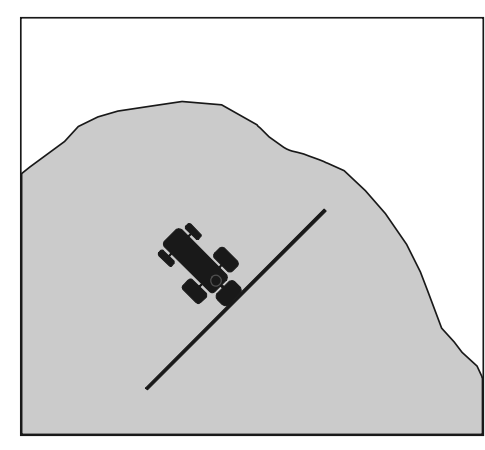

(A)

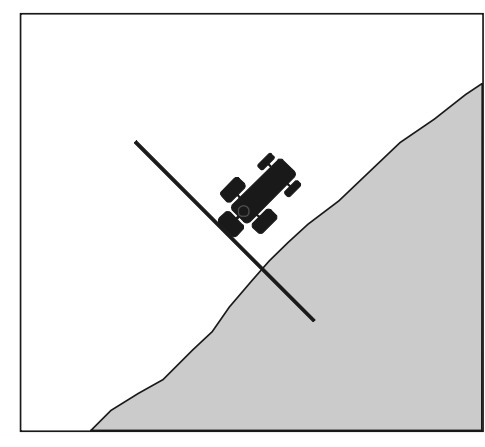

(B)

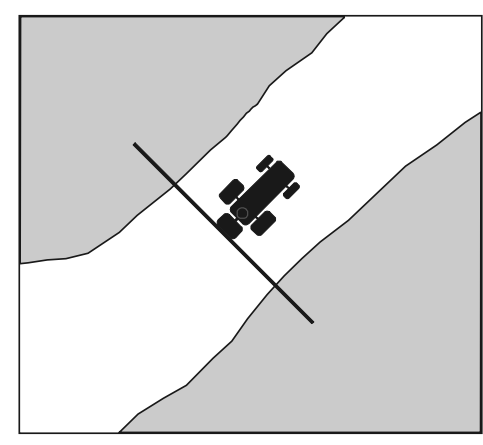

(C)

Figura 15 - Situação em que o centro do pulverizador encontra-se no interior de uma mancha de infestação (A), ou fora dela, porém com uma (B) ou duas (C) seções sobre manchas distintas.

No entanto, se o pixel do local onde o círculo vermelho foi alocado na tela não é azul, significa que o centro do pulverizador não se encontra numa mancha de plantas daninhas. Isto não quer dizer que a pulverização não deva ocorrer, pois o círculo vermelho representa a localização da antena, situada no centro do trator. Pode ocorrer a situação em que o centro do pulverizador se encontre fora de uma mancha de infestação, mas com uma, ou até ambas seções da barra sobre infestações (Figuras 15B e 15C). Para se observar esta possibilidade, o programa dá seqüência a uma série de cálculos trigonométricos a fim de verificar se alguma fração da barra de pulverização encontra-se sobre uma mancha de infestação. 
O primeiro procedimento é determinar a distância entre o pulverizador e a mancha de infestação mais próxima. Este cálculo é realizado utilizando-se das coordenadas extraídas do arquivo de prescrição. O programa calcula a distância entre o ponto atual do pulverizador e cada um dos pontos formadores das manchas de infestação através da eq. (1).

$$
\text { distância }=\sqrt{\left(\mathrm{x}_{\mathrm{M}}-\mathrm{x}_{\mathrm{P}}\right)^{2}+\left(\mathrm{y}_{\mathrm{M}}-\mathrm{y}_{\mathrm{P}}\right)^{2}}
$$

onde:

$\mathrm{X}_{\mathrm{M}}=$ longitude de um ponto formador de uma mancha de infestação

$\mathrm{Y}_{\mathrm{M}}=$ latitude de um ponto formador de uma mancha de infestação

$\mathrm{X}_{\mathrm{P}}=$ longitude do ponto atual do pulverizador

$\mathrm{Y}_{\mathrm{P}}=$ latitude do ponto atual do pulverizador

Se a distância encontrada for menor ou igual a metade do comprimento da barra de pulverização, uma das seções pode estar sobre uma mancha de plantas daninhas. Assim, o programa dá seqüência aos cálculos para estabelecer uma projeção da barra e, a partir daí, definir onde estão localizadas as suas extremidades. Conhecendose estes dois pontos pode-se determinar, novamente pela cor do pixel, se os mesmos encontram-se sobre manchas de infestação.

Para se definir a projeção da barra, o programa utiliza as coordenadas atuais e as últimas coordenadas registradas. Conhecendo-se estes dois pontos, o programa traça uma reta, unindo-os, estabelecendo, desta forma, a trajetória do trator e, conseqüentemente, do pulverizador. Existem três trajetórias de deslocamento possíveis: longitudinal, transversal e inclinada. Além da trajetória, o programa define também o sentido de caminhamento para identificar os lados direito e esquerdo da barra de pulverização. A Figura 16 ilustra todas as possibilidades e as letras correspondem a:

$$
\mathrm{X}_{0}=\text { longitude do ponto anterior }
$$


$\mathrm{Y}_{0}=$ latitude do ponto anterior

$\mathrm{X}_{1}=$ longitude do ponto atual

$\mathrm{Y}_{1}=$ latitude do ponto atual

$\mathrm{PD}_{\mathrm{X}}=$ longitude da extremidade direita da barra

$\mathrm{PD}_{\mathrm{Y}}=$ latitude da extremidade direita da barra

$\mathrm{PE}_{\mathrm{X}}=$ longitude da extremidade esquerda da barra

$\mathrm{PE}_{\mathrm{Y}}=$ latitude da extremidade esquerda da barra 


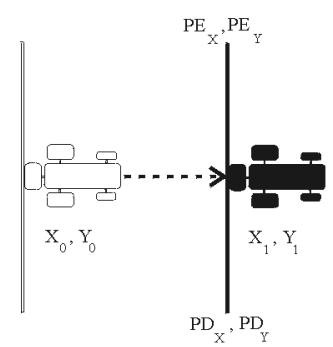

LONGITUDINAL

À DIREITA

(a)

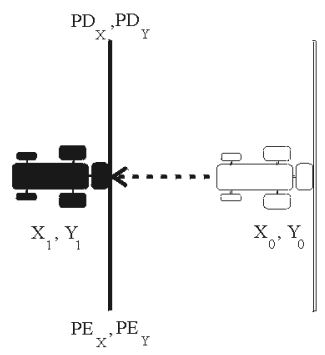

LONGITUDINAL

A ESQUERDA

(b)

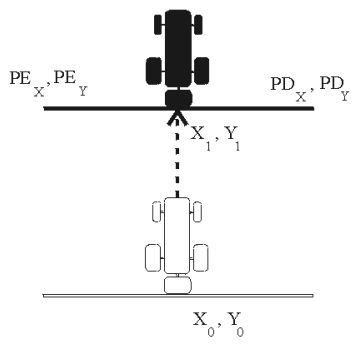

TransversaL

PARA CIMA

(c)

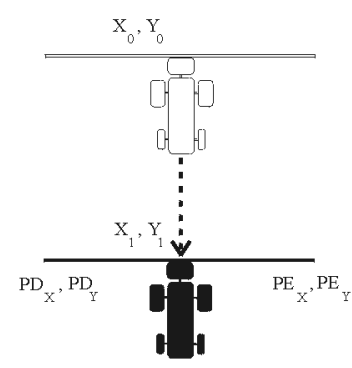

TRANSVERSAL

PARA BAIXO

(d)

INCLINADA

PARA CIMA

À DIREITA

(e)

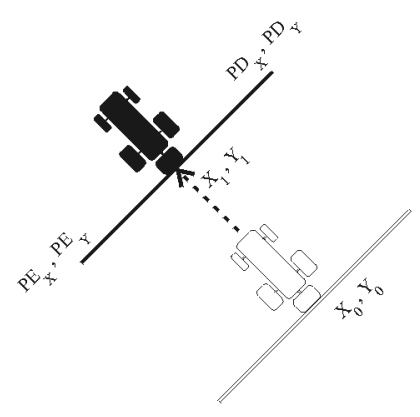

INCLINADA

PARA CIMA

À ESQUERDA

(f)

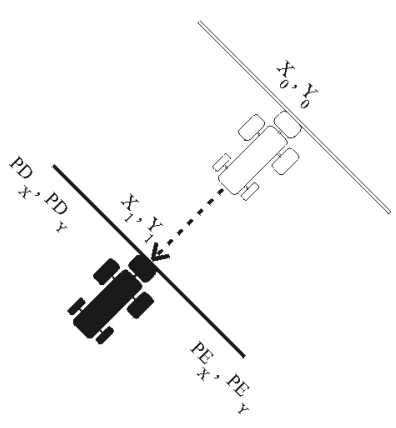

INCLINADA PARABAIXO À DIREITA

(g)

(h)

Figuras 16 - Possíveis trajetórias e sentidos de deslocamento do trator.

A trajetória longitudinal (mostrada nos croquis a e b da Figura 16) é explicada pela Figura 17. 


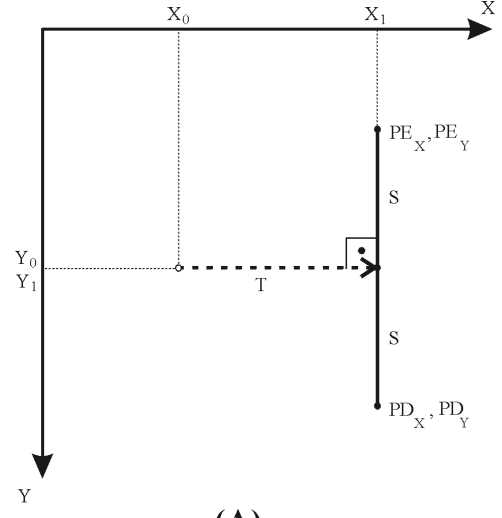

(A)

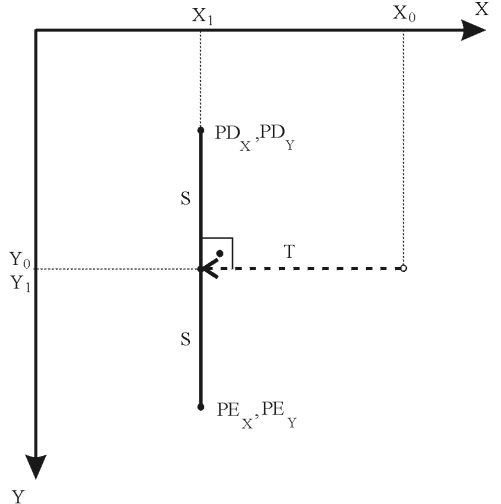

(B)

Figura 17 - Trajetória longitudinal do trator, com caminhamento à direita (A) e à esquerda (B).

Na Figura 17 são mostrados os dois sentidos na trajetória longitudinal: à direita (A) e à esquerda (B). As coordenadas do ponto anterior são representadas por $\mathrm{X}_{0}, \mathrm{Y}_{0}$ e as coordenadas atuais, por $\mathrm{X}_{1}, \mathrm{Y}_{1}$. Estes dois conjuntos de coordenadas são conhecidos pelo programa, tendo sido fornecidos pelo DGPS. Os valores a serem encontrados se referem às coordenadas das pontas direita $\left(\mathrm{PD}_{\mathrm{X}}, \mathrm{PD}_{\mathrm{Y}}\right)$ e esquerda $\left(\mathrm{PE}_{\mathrm{X}}\right.$, $\left.\mathrm{PE}_{\mathrm{Y}}\right)$ da barra de pulverização. A trajetória do trator é definida pela reta $\mathrm{T}$ e o tamanho da seção da barra é representado por S. A trajetória longitudinal somente ocorre quando não há variação dos valores do eixo Y, das latitudes, ou seja, quando é estabelecida a igualdade expressa pela eq. (2).

$$
\mathrm{Y}_{0}=\mathrm{Y}_{1}
$$

Quando em trajetória longitudinal, as coordenadas das extremidades da barra de pulverização são definidas por:

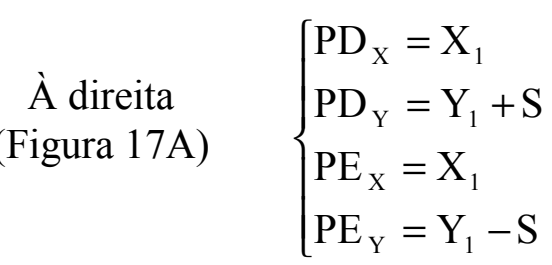


À esquerda
(Figura 17B) $\left\{\begin{array}{l}\mathrm{PD}_{\mathrm{X}}=\mathrm{X}_{1} \\ \mathrm{PD}_{\mathrm{Y}}=\mathrm{Y}_{1}-\mathrm{S} \\ \mathrm{PE}_{\mathrm{X}}=\mathrm{X}_{1} \\ \mathrm{PE}_{\mathrm{Y}}=\mathrm{Y}_{1}+\mathrm{S}\end{array}\right.$

onde,

$\mathrm{S}=$ comprimento da seção da barra do pulverizador.

A trajetória transversal (croquis c e d da Figura 16) é explicada pela Figura 18. Nesta situação, não ocorre variação dos valores do eixo das longitudes (X), sendo estabelecida a igualdade expressa pela eq. (11).

$$
\mathrm{X}_{0}=\mathrm{X}_{1}
$$

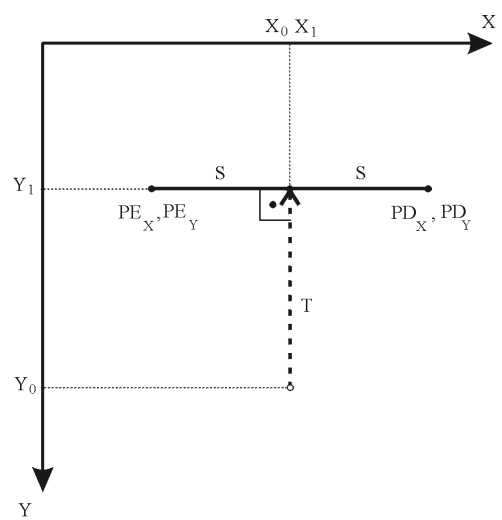

(A)

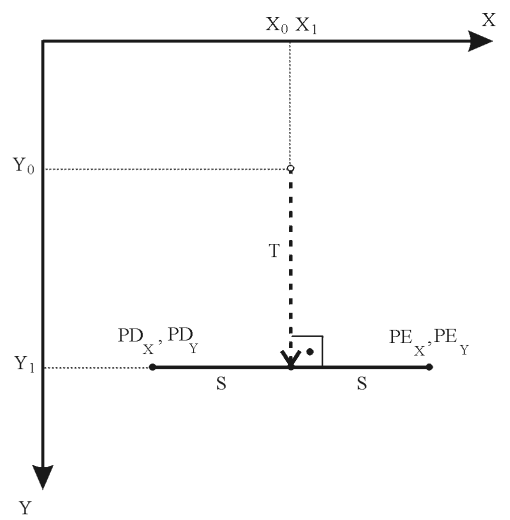

(B)

Figura 18 - Trajetória transversal do trator, com caminhamento para cima (A) e para baixo (B).

Quando em trajetória transversal, as coordenadas das pontas da barra de pulverização são definidas pelas equações:

$$
\text { (Figura 18A) }\left\{\begin{array}{l}
\mathrm{PD}_{\mathrm{X}}=\mathrm{X}_{1}+\mathrm{S} \\
\mathrm{PD}_{\mathrm{Y}}=\mathrm{Y}_{1} \\
\mathrm{PE}_{\mathrm{X}}=\mathrm{X}_{1}-\mathrm{S} \\
\mathrm{PE}_{\mathrm{Y}}=\mathrm{Y}_{1}
\end{array}\right.
$$


(Figura 18B) $\left\{\begin{array}{l}\mathrm{PD}_{\mathrm{X}}=\mathrm{X}_{1}-\mathrm{S} \\ \mathrm{PD}_{\mathrm{Y}}=\mathrm{Y}_{1} \\ \mathrm{PE}_{\mathrm{X}}=\mathrm{X}_{1}+\mathrm{S} \\ \mathrm{PE}_{\mathrm{Y}}=\mathrm{Y}_{1}\end{array}\right.$

Quando as igualdades das equações (2) e (11) não são estabelecidas, a trajetória do trator não é longitudinal e nem transversal. Na trajetória inclinada, existem quatro possibilidades para definição do sentido de caminhamento do trator, explicadas pela Figura 19.

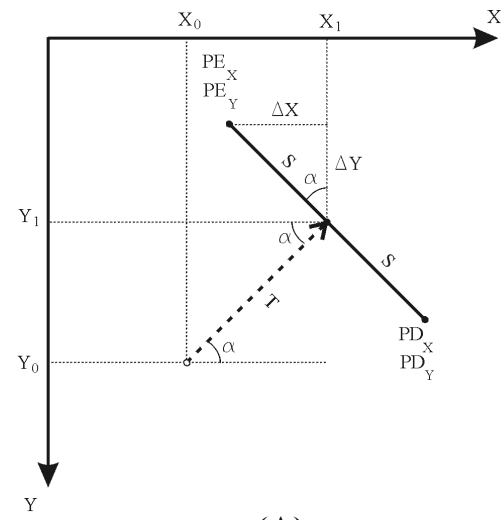

(A)

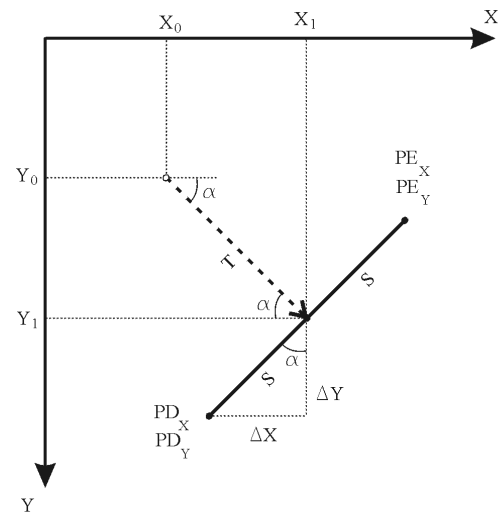

(C)

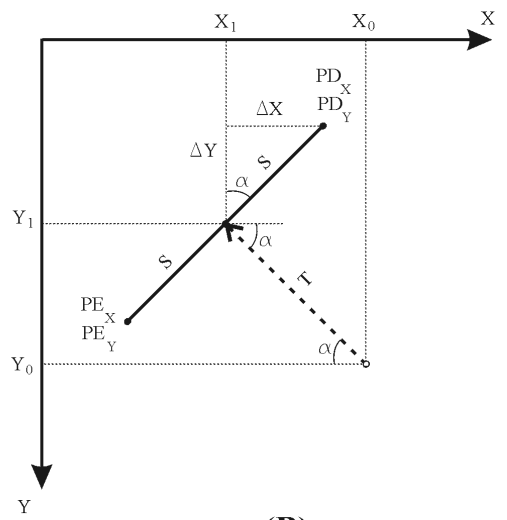

(B)

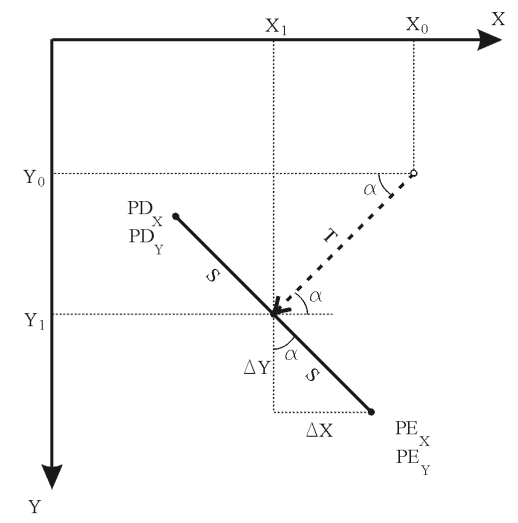

(D)

Figura 19 - Trajetória inclinada, com caminhamento do trator para cima à direita $(\mathrm{A})$, para cima à esquerda (B), para baixo à esquerda $(\mathrm{C})$ e para baixo à direita (D). 
As condições para que ocorra cada uma dessas possibilidades estão expressas nas equações:

$$
\begin{array}{ll}
\begin{array}{l}
\text { Para cima à direita } \\
\text { (Figura 19A) }
\end{array} & \left\{\begin{array}{l}
\mathrm{X}_{0} \leq \mathrm{X}_{1} \\
\mathrm{e} \\
\mathrm{Y}_{0}>\mathrm{Y}_{1}
\end{array}\right. \\
\begin{array}{c}
\text { Para cima à esquerda } \\
\text { (Figura 19B) } \\
\begin{array}{c}
\text { (Figura 19C) } \\
\text { Para baixo à esquerda }
\end{array}
\end{array} & \left\{\begin{array}{l}
\mathrm{X}_{0} \geq \mathrm{X}_{1} \\
\mathrm{e} \\
\mathrm{Y}_{0}>\mathrm{Y}_{1}
\end{array}\right. \\
\begin{array}{l}
\mathrm{X}_{0} \leq \mathrm{X}_{1} \\
\mathrm{e} \\
\mathrm{Y}_{0}<\mathrm{Y}_{1}
\end{array} \\
\begin{array}{l}
\text { (Figura 19D) } \\
\mathrm{X}_{0} \geq \mathrm{X}_{1} \\
\mathrm{e} \\
\mathrm{Y}_{0}<\mathrm{Y}_{1}
\end{array}
\end{array}
$$

Para todos os casos mostrados na Figura 19, a determinação das coordenadas das extremidades da barra $\left(\mathrm{PD}_{\mathrm{X}}, \mathrm{PD}_{\mathrm{Y}}\right.$ e $\left.\mathrm{PE}_{\mathrm{X}}, \mathrm{PE}_{\mathrm{Y}}\right)$ é feita considerando-se $\alpha$, que é o ângulo formado entre a projeção da barra e a vertical. O ângulo $\alpha$ é definido por:

$$
\alpha=\operatorname{arctg}\left(\frac{Y_{1}-Y_{0}}{X_{1}-X_{0}}\right)
$$

Conhecendo-se o valor do ângulo $\alpha$ pode-se determinar os valores de $\Delta \mathrm{X}$ e de $\Delta Y$ :

$$
\begin{aligned}
& \Delta \mathrm{X}=\mathrm{S} \times \operatorname{sen}(\alpha) \\
& \Delta \mathrm{Y}=\mathrm{S} \times \cos (\alpha)
\end{aligned}
$$

onde, 
$\Delta \mathrm{X}=$ variação das longitudes entre as extremidades da barra e o ponto atual do pulverizador

$\Delta \mathrm{Y}=$ variação das latitudes entre as extremidades da barra e o ponto atual do pulverizador

Assim, as coordenadas das extremidades da barra de pulverização são definidas pelas equações:

Para cima à direita
(Figura 19A) $\quad\left\{\begin{array}{l}\mathrm{PD}_{\mathrm{X}}=\mathrm{X}_{1}+\Delta \mathrm{X} \\ \mathrm{PD}_{\mathrm{Y}}=\mathrm{Y}_{1}+\Delta \mathrm{Y} \\ \mathrm{PE}_{\mathrm{X}}=\mathrm{X}_{1}-\Delta \mathrm{X} \\ \mathrm{PE}_{\mathrm{Y}}=\mathrm{Y}_{1}-\Delta \mathrm{Y}\end{array}\right.$

Para cima à esquerda
(Figura 19B) $\quad\left\{\begin{array}{l}\mathrm{PD}_{\mathrm{X}}=\mathrm{X}_{1}+\Delta \mathrm{X} \\ \mathrm{PD}_{\mathrm{Y}}=\mathrm{Y}_{1}-\Delta \mathrm{Y} \\ \mathrm{PE}_{\mathrm{X}}=\mathrm{X}_{1}-\Delta \mathrm{X} \\ \mathrm{PE}_{\mathrm{Y}}=\mathrm{Y}_{1}+\Delta \mathrm{Y}\end{array}\right.$

Para baixo à esquerda
(Figura 19C) $\left\{\begin{array}{l}\mathrm{PD}_{\mathrm{X}}=\mathrm{X}_{1}-\Delta \mathrm{X} \\ \mathrm{PD}_{\mathrm{Y}}=\mathrm{Y}_{1}+\Delta \mathrm{Y} \\ \mathrm{PE}_{\mathrm{X}}=\mathrm{X}_{1}+\Delta \mathrm{X} \\ \mathrm{PE}_{\mathrm{Y}}=\mathrm{Y}_{1}-\Delta \mathrm{Y}\end{array}\right.$

Para baixo à direita
(Figura 19D) $\left\{\begin{array}{l}\mathrm{PD}_{\mathrm{X}}=\mathrm{X}_{1}-\Delta \mathrm{X} \\ \mathrm{PD}_{\mathrm{Y}}=\mathrm{Y}_{1}-\Delta \mathrm{Y} \\ \mathrm{PE}_{\mathrm{X}}=\mathrm{X}_{1}+\Delta \mathrm{X} \\ \mathrm{PE}_{\mathrm{Y}}=\mathrm{Y}_{1}+\Delta \mathrm{Y}\end{array}\right.$ 
De posse das coordenadas das extremidades da barra, o programa verifica a cor do pixel dessas posições na tela do computador. Assim, só vão ser acionadas as seções cuja extremidade se situe numa região de pixeis azuis.

e) Acionamento das válvulas solenóides

Ao decidir quais seções devem ser acionadas, o programa realiza o controle das válvulas solenóides por meio da interface de acionamento, descrita no item 3.1.8.

\section{f) Registro de aplicação}

A função do registro de aplicação é armazenar as coordenadas dos locais onde ocorre o acionamento das válvulas solenóides. Uma rotina armazena os dados de latitude, longitude e válvula acionada num arquivo texto.

A Figura 20 ilustra o fluxograma final do programa computacional. 


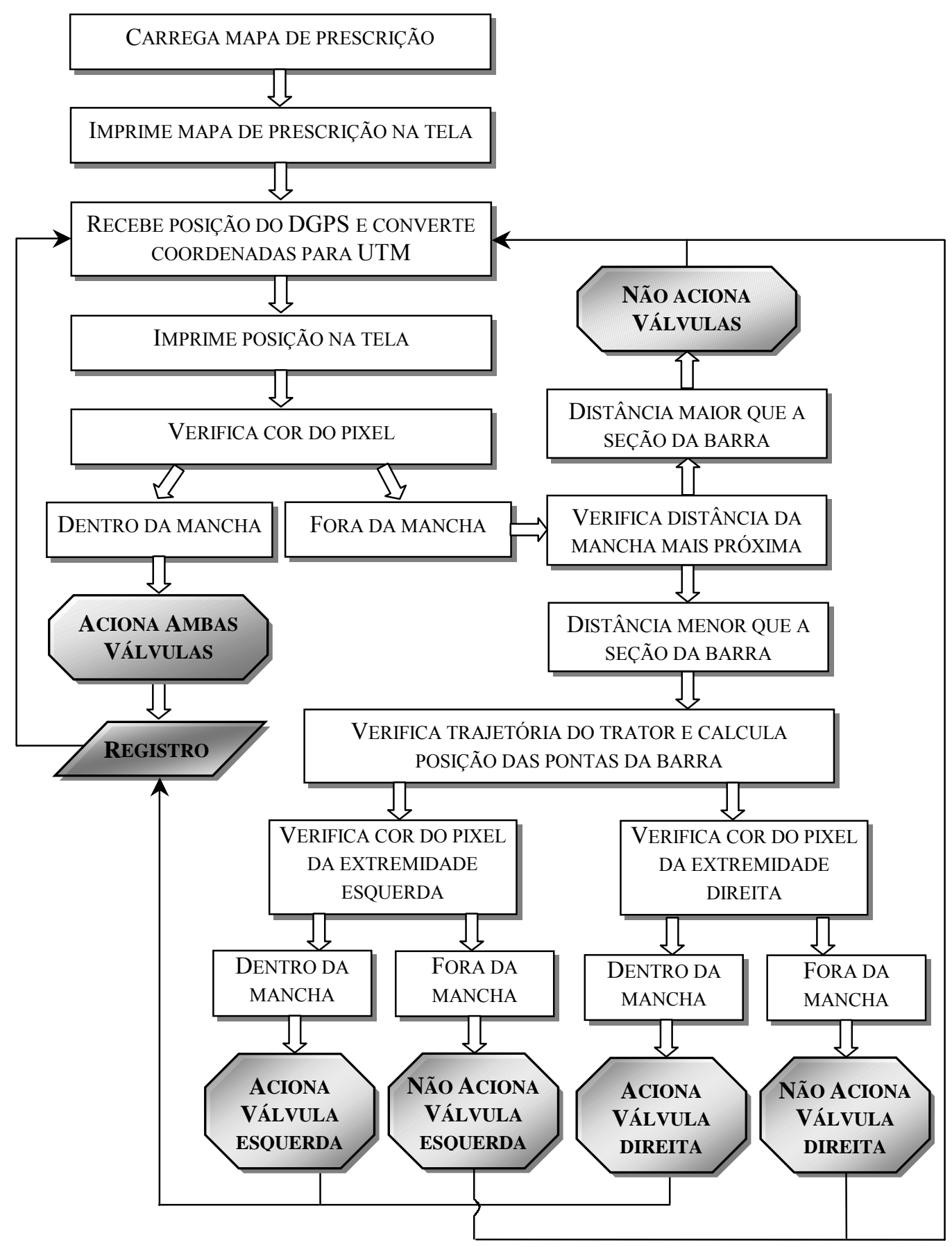

Figura 20 - Fluxograma do programa computacional. 


\subsubsection{Avaliação das versões em desenvolvimento}

As versões em desenvolvimento foram avaliadas na área gramada, sobre a região mapeada, com o uso dos equipamentos descritos no item 3.1.7. Ao longo do processo de desenvolvimento, foram utilizados três percursos com o trator e a plataforma sobre a mancha de infestação hipotética. Estes percursos simularam a passagem do pulverizador no interior da mancha e ao seu redor, como mostra a Figura 21.

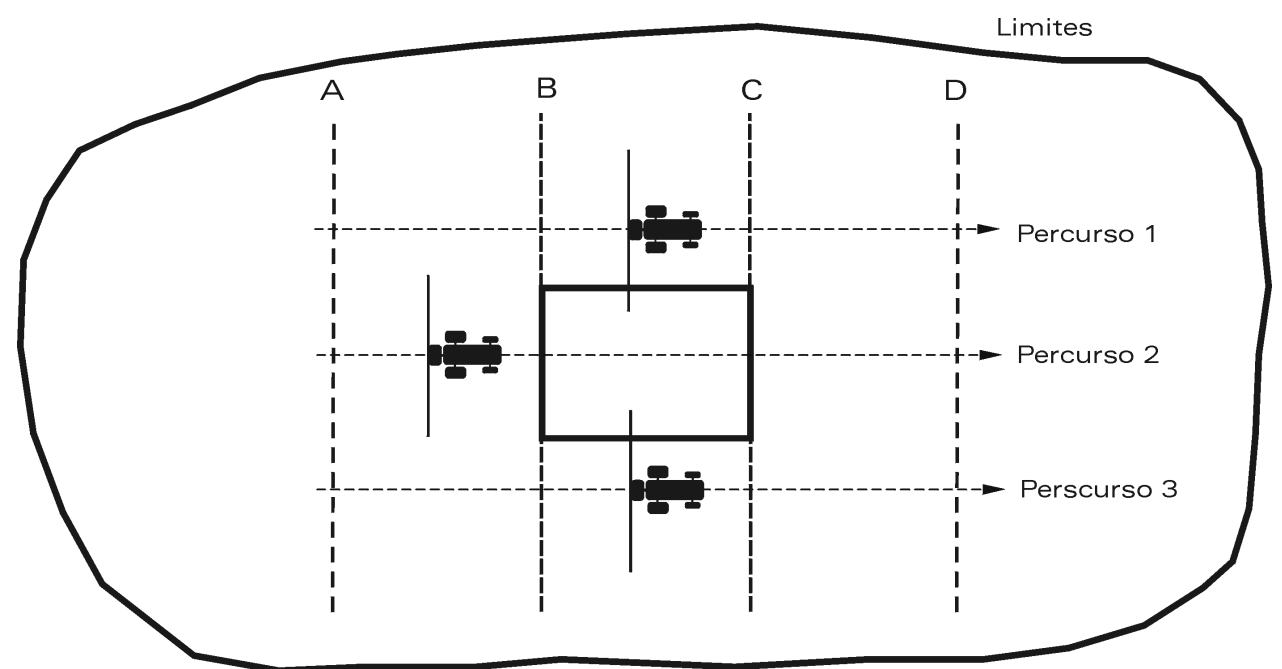

Figura 21 - Percursos realizados na avaliação das versões em desenvolvimento.

Os três percursos eram iniciados na posição A e terminavam na posição D. O retângulo no centro da figura mostra a mancha de infestação hipotética, com início na posição B e término na posição C. A distância entre os percursos 1 e 3 e a borda da mancha foi suficiente para que as extremidades da barras entrassem um metro na região demarcada pela fita amarela. Ao executar os percursos, os LEDs eram observados para se verificar o acionamento das seções de barra. Neste processo de desenvolvimento e de verificação do funcionamento do programa, utilizou-se baixa velocidade $\left(0,4 \mathrm{~m}_{\mathrm{s}} \mathrm{s}^{-1}\right.$ ou $\left.1,5 \mathrm{~km} \cdot \mathrm{h}^{-1}\right)$. A adoção dessa velocidade teve por objetivo evitar problemas com o tempo de atualização das informações de posicionamento, já que, a cada segundo, uma nova 
informação é enviada pelo DGPS, processada pelo programa e impressa na tela. Entretanto, por se tratar de um veículo em movimento, a informação recebida pode não ser mais referente ao local em que o veículo está situado no momento, mas sim de um local já visitado por ele. Para que este tipo de erro pudesse ser evitado em velocidades maiores, foi necessária a utilização de uma bordadura de segurança, como será abordado no item a seguir.

\subsubsection{Bordadura de segurança para evitar falhas de pulverização nas margens das manchas}

Assim como relatado no item anterior, a definição de uma bordadura de segurança ao redor das manchas de infestação foi necessária para evitar erros referentes ao tempo de atualização da informação de posicionamento sob velocidades mais elevadas. Este tipo de erro pode ocorrer somente na transição entre uma área infestada e outra não infestada. A Figura 22 mostra uma situação em que o trator entra numa mancha de infestação.

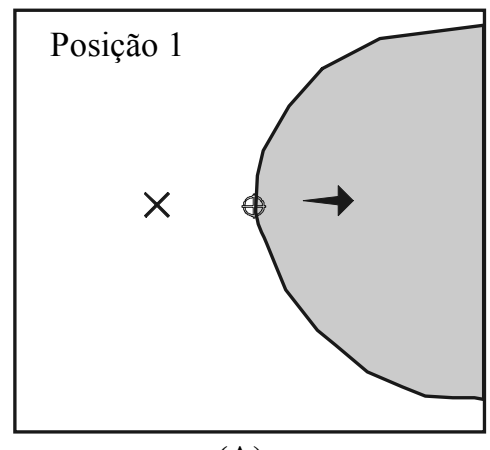

(A)

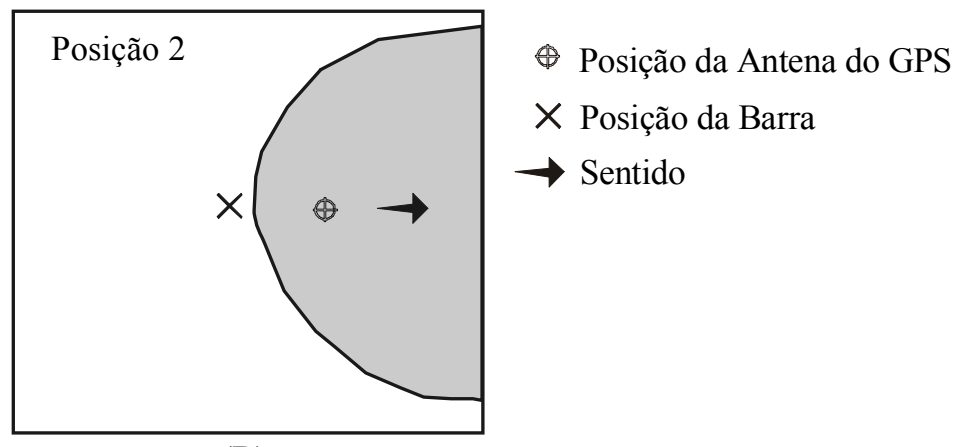

(B)

Figura 22 - Trator entrando numa mancha de infestação.

O círculo representa a posição da antena do GPS, localizada no teto do trator. A posição da barra é representada pelo " $X$ ", distante 1,5 $\mathrm{m}$ da antena. Na Figura $22^{\mathrm{A}}$, a antena está às margens de uma mancha, muito próximo dela, mas ainda fora dela. Considerando-se o tempo de um segundo para atualização da informação de 
posicionamento e a velocidade de $1,1 \mathrm{~m} \cdot \mathrm{s}^{-1}\left(4,0 \mathrm{~km} / \mathrm{h}^{-1}\right)$ do trator, a próxima informação será enviada 1,1 m depois. Neste ponto (Figura 22B), o trator já estará no interior da mancha. Devido a distância entre a antena e a barra, a falha não ocorre, uma vez que a barra ainda se encontra fora da mancha. Porém, na saída de uma mancha, a falha pode vir a ocorrer, conforme mostra a Figura 23, onde o trator se encontra trafegando para a direita, saindo de uma mancha.

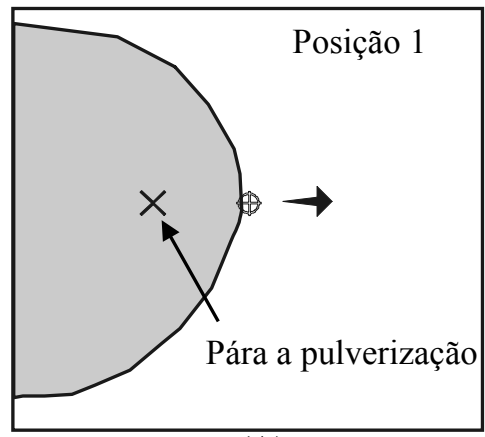

(A)

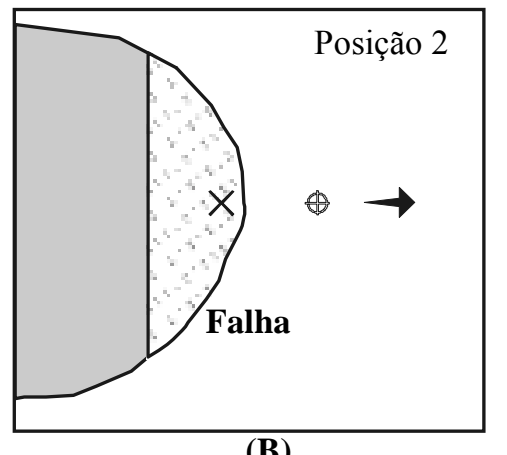

(B)

Figura 23 - Trator saindo de uma mancha de infestação.

$\mathrm{Na}$ Figura 23A, a posição enviada pelo DGPS indica que a antena já saiu da mancha, mas está muito próxima dela, às suas margens. Nesta situação, as válvulas são desligadas e a pulverização pára; porém a barra do pulverizador ainda encontra-se no interior da mancha e, a partir desse ponto, o controle não é efetuado, dando origem às falhas (Figura 23B).

Considerando este tipo de erro, optou-se por utilizar uma bordadura de segurança ao redor das infestações de, aproximadamente, 1,5 m, valor capaz de evitar falhas de pulverização devidas a esse erro.

\subsubsection{Teste do sistema numa situação real de controle}

O sistema desenvolvido foi submetido a um teste em condições reais de controle de plantas daninhas, a fim de se avaliar eficácia do equipamento em atingir os 
alvos (manchas), assim como determinar a redução de herbicida alcançada pelo sistema, em comparação ao controle convencional.

Os testes foram feitos na área de reforma de canavial de 4,1 ha da Usina Costa Pinto. Esta fase foi dividida em quatro subetapas:

- Mapeamento das plantas daninhas;

- Criação do mapa de prescrição;

- Aplicação localizada de herbicida;

- Avaliação dos resultados.

\subsubsection{Mapeamento das plantas daninhas}

A metodologia empregada no mapeamento das plantas daninhas foi a do georreferenciamento do perímetro das infestações, descrita por Colliver et al. (1996) e avaliada por Balastreire \& Baio (2001b). Neste método, o mapeamento é feito pelo caminhamento ao redor das infestações, cujos limites são identificados visualmente.

Os equipamentos utilizados no mapeamento foram os mesmo empregados para a criação do mapa de prescrição hipotético, descritos no item 3.1.9. Após o estabelecimento da estação base, iniciaram-se os mapeamentos. O primeiro mapa criado foi o do contorno do talhão, tendo sido percorrido todo seu perímetro. De posse do mapa dos limites do talhão, criou-se uma grade de $20 \times 20 \mathrm{~m}$ na tela do Palmtop para facilitar o mapeamento das plantas daninhas. Todas as manchas encontradas foram mapeadas e diferenciadas somente em termos de espécies. Não se utilizaram pesos ou notas para diferenciação do porte da planta ou densidade de infestação.

\subsubsection{Criação do mapa de prescrição}

Toda metodologia empregada para a criação do mapa de prescrição da área real foi a mesma utilizada na obtenção do mapa de infestação hipotético, descrita no item 3.2.2. 
Conforme relatado no item 3.2.3.2, foi utilizada uma borda de segurança de 1,50 m ao redor das infestações para evitar falhas de pulverização.

\subsubsection{Aplicação localizada}

Antes do início da operação de aplicação localizada, fez-se a calibração do pulverizador. Escolheu-se a combinação de marcha para que o trator trafegasse com velocidade de $1,1 \mathrm{~m} \cdot \mathrm{s}^{-1}\left(4,0 \mathrm{~km} \cdot \mathrm{h}^{-1}\right)$ e rotação de $540 \mathrm{rpm}$ na TDP. Foram utilizados bicos tipo leque, malha 50 e a pressão de trabalho do pulverizador foi ajustada para $275,79 \mathrm{kPa}\left(40 \mathrm{lbf}\right.$.pol $\left.{ }^{-2}\right)$. Mediu-se o tempo gasto pelo pulverizador para percorrer $50 \mathrm{~m}$ na marcha escolhida e coletou-se o volume pulverizado pelos bicos durante esse tempo. Nestas configurações, o pulverizador foi ajustado para aplicar um volume de calda de 200 L.ha $^{-1}$. Desta forma, foram diluídos 8 L de Roundup em 400 L colocados no tanque do pulverizador, para que a dosagem do herbicida fosse de 4,0 L.ha ${ }^{-1}$.

A dosagem do herbicida foi definida de acordo com a recomendação do fabricante do produto, em função da planta daninha de maior ocorrência e de maior dificuldade de controle.

Os equipamentos utilizados nesta etapa foram descritos no item 3.1.10. O trator foi posicionado numa das extremidades do talhão, o DGPS e o computador foram ligados e iniciou-se o programa para controle das válvulas. Carregou-se o mapa de prescrição e abriu-se o arquivo de registro.

O operador realizou a aplicação localizada como se fosse uma tarefa normal de pulverização. Não se utilizou nenhum artifício para orientação do operador com relação ao paralelismo das passadas, como barra de luzes, marcador de espuma ou correntes. A orientação foi feita visualmente, adotando-se como referência a marca dos pneus feita na passagem anterior do trator. Após o término da aplicação, o arquivo de registro foi fechado e anotou-se a quantidade de calda restante no tanque, através do marcador de nível do pulverizador. 


\subsubsection{Avaliação dos resultados}

A análise dos resultados foi feita avaliando-se os seguintes itens:

$\Rightarrow$ Identificação visual do controle;

$\Rightarrow$ Mapeamento das manchas não controladas: feito trinta dias após a aplicação do herbicida. Foram utilizados os mesmos equipamentos descritos no item 3.1.9;

$\Rightarrow$ Sobreposição do mapa de aplicação (registro) ao mapa de prescrição, no programa SSToolBox;

$\Rightarrow$ Determinação da economia de herbicida em comparação ao tratamento convencional: levou-se em conta a quantidade de calda na aplicação localizada e a quantidade de calda que seria gasta caso o controle fosse feito em área total. 


\section{RESULTADOS E DISCUSSÃO}

\subsection{Montagem do sistema}

Uma avaliação inicial feita com o tanque do pulverizador cheio d'água acoplado ao trator e a conexão direta das válvulas solenóides a uma bateria de $12 \mathrm{~V}$ mostrou um tempo de resposta extremamente baixo do equipamento. Ou seja, com a TDP do trator acionada e o registro para os bicos aberto para ambas seções, a pulverização iniciou-se instantaneamente quando as válvulas solenóides foram acionadas. A existência de válvulas antigotejo nos bicos de pulverização favoreceu esse baixo tempo, uma vez que as mangueiras e a tubulação estavam sempre cheias d'água. Assim, o uso de válvulas solenóides para realizar a simples função liga-desliga (passagem ou não passagem da calda às barras) pode ser considerado uma opção ágil, conforme relataram Paice at al., 1996.

\subsection{Desenvolvimento do programa computacional para controle do pulverizador}

A utilização da plataforma de testes e dos LEDs, em substituição ao pulverizador e as válvulas, respectivamente, permitiu um processo mais rápido e eficiente no desenvolvimento do programa computacional utilizado neste trabalho, o qual somente se encerrou quando obteve-se o acionamento esperado dos LEDs nos percursos feitos com a plataforma de testes sobre a área com a mancha de infestação hipotética (como mostrou a Figura 21, do item 3.2.3.1). Os resultados finais são exibidos na Tabela 2. 
Tabela 2. Acionamento dos LEDs ao longo dos três percursos.

\begin{tabular}{cccc}
\hline & \multicolumn{3}{c}{ INTERVALOS } \\
PERCURSOS & A-B & B-C & C-D \\
\hline 1 & nenhum & direito & nenhum \\
2 & nenhum & ambos & nenhum \\
3 & nenhum & esquerdo & nenhum \\
\hline
\end{tabular}

Estes resultados podem ser visualizados pela Figura 24, que mostra o arquivo de registro, gerado ao longo dos percursos, sobreposto ao mapa de prescrição. As setas indicam o sentido de caminhamento do trator e os símbolos da legenda indicam os LEDs acionados.

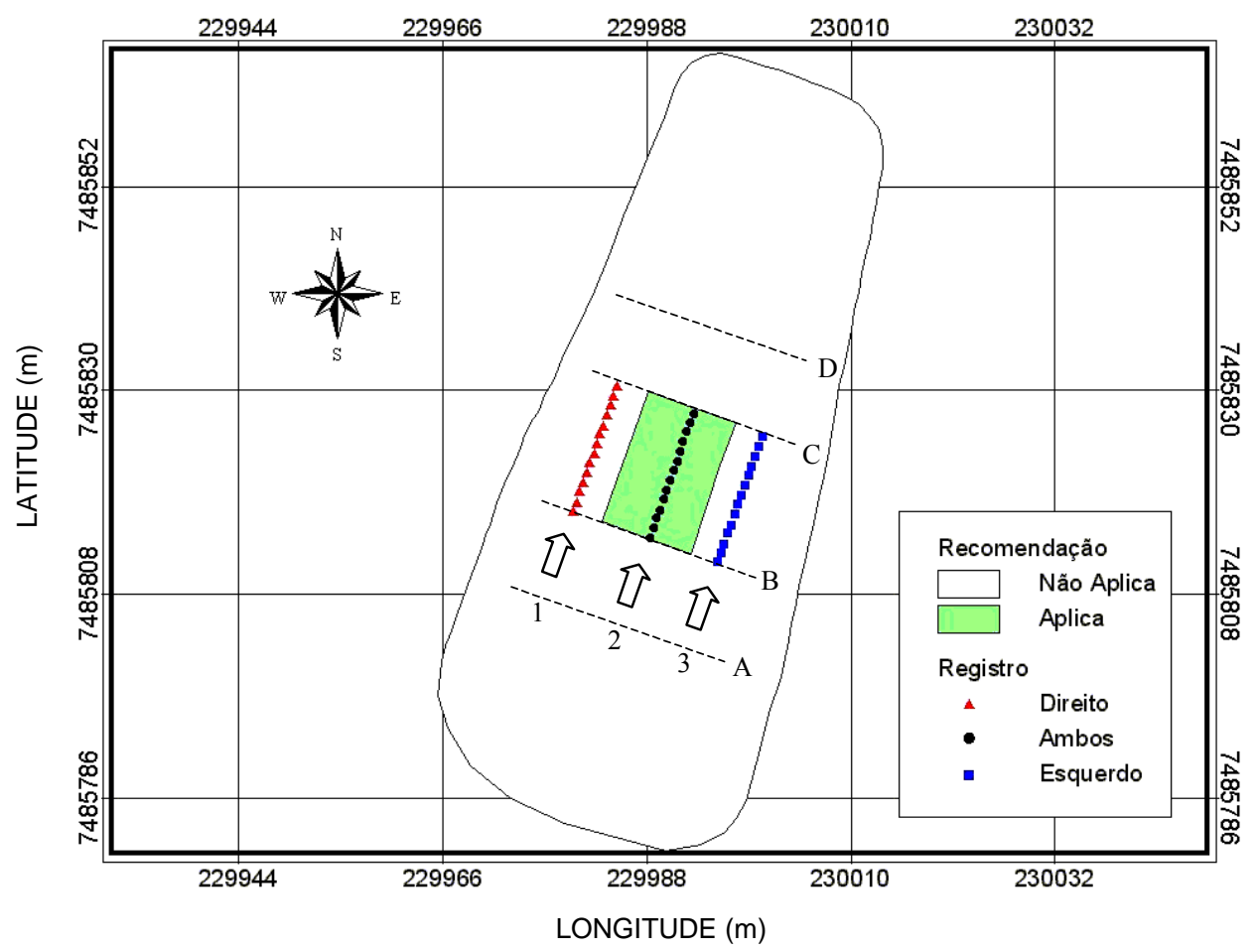

Figura 24 - Mapa de registro sobreposto ao mapa de prescrição.

De acordo com a Figura 24, o acionamento dos LEDs foi efetuado de forma correta e o controle independente das seções se mostrou eficiente. Verificou-se que os acionamentos ocorreram muito próximos aos limites da mancha (linhas B e C). Entretanto, deve-se ressaltar que estes resultados foram obtidos trafegando-se a uma 
velocidade baixa, para que se pudesse verificar o funcionamento do programa. Desta forma, os problemas envolvendo o tempo de atualização das informações foram minimizados.

A Figura 25 mostra a tela do programa desenvolvido, com o mapa de prescrição hipotético carregado.

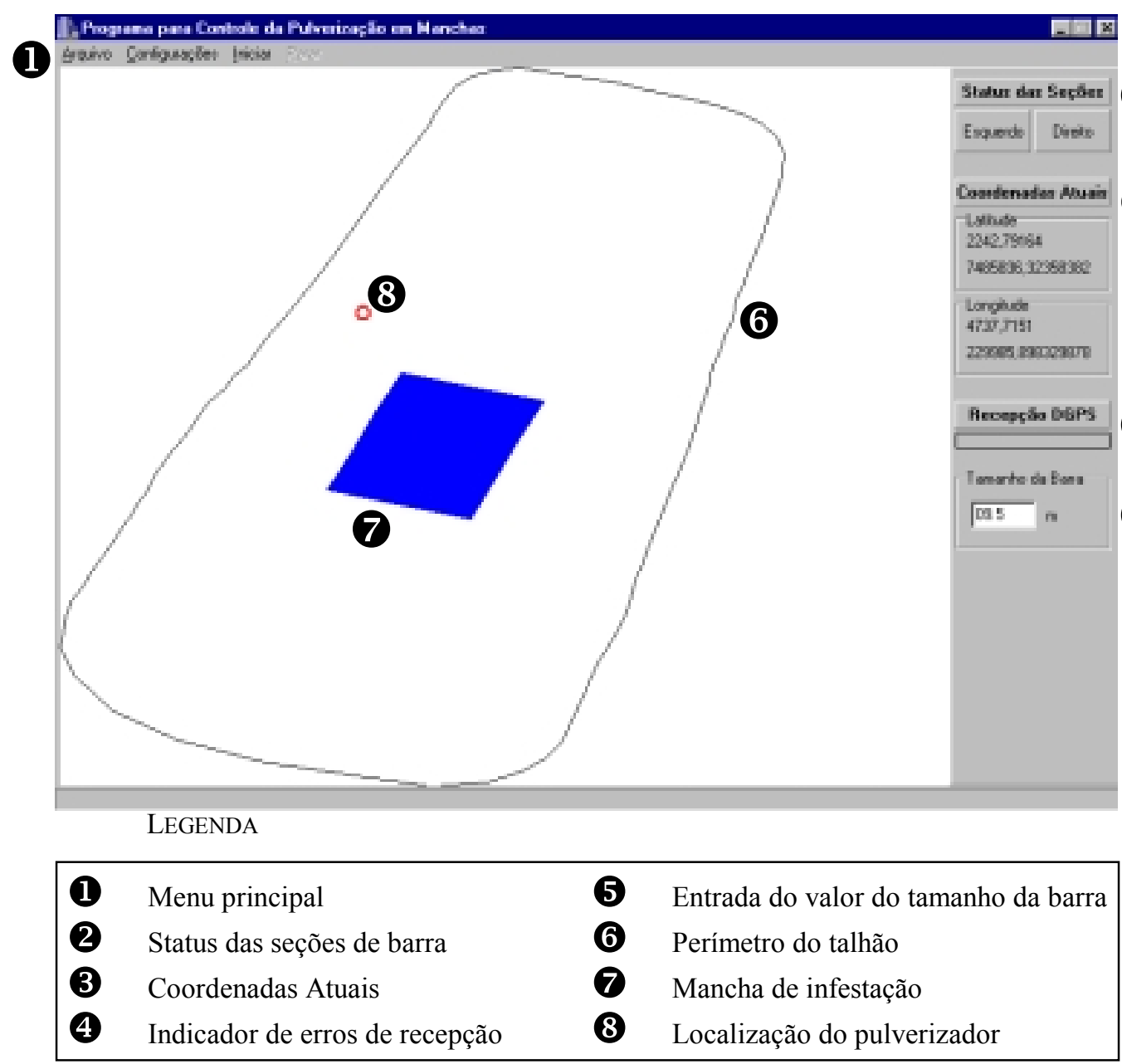

Figura 25 - Tela do programa desenvolvido.

As funções do menu principal, mostrado nas Figuras 26A e 26B, são as seguintes:

- Carregar o mapa de prescrição (são aceitos somente arquivos com extensão arx, produzidos conforme relatado na metodologia). 
- Fechar o arquivo de prescrição.

- Iniciar e fechar um arquivo de registro ( $\log )$, em formato texto.

- Configurar parâmetros de comunicação entre o Notebook e o DGPS.

- Iniciar e parar o controle das válvulas solenóides, via porta serial de comunicação.

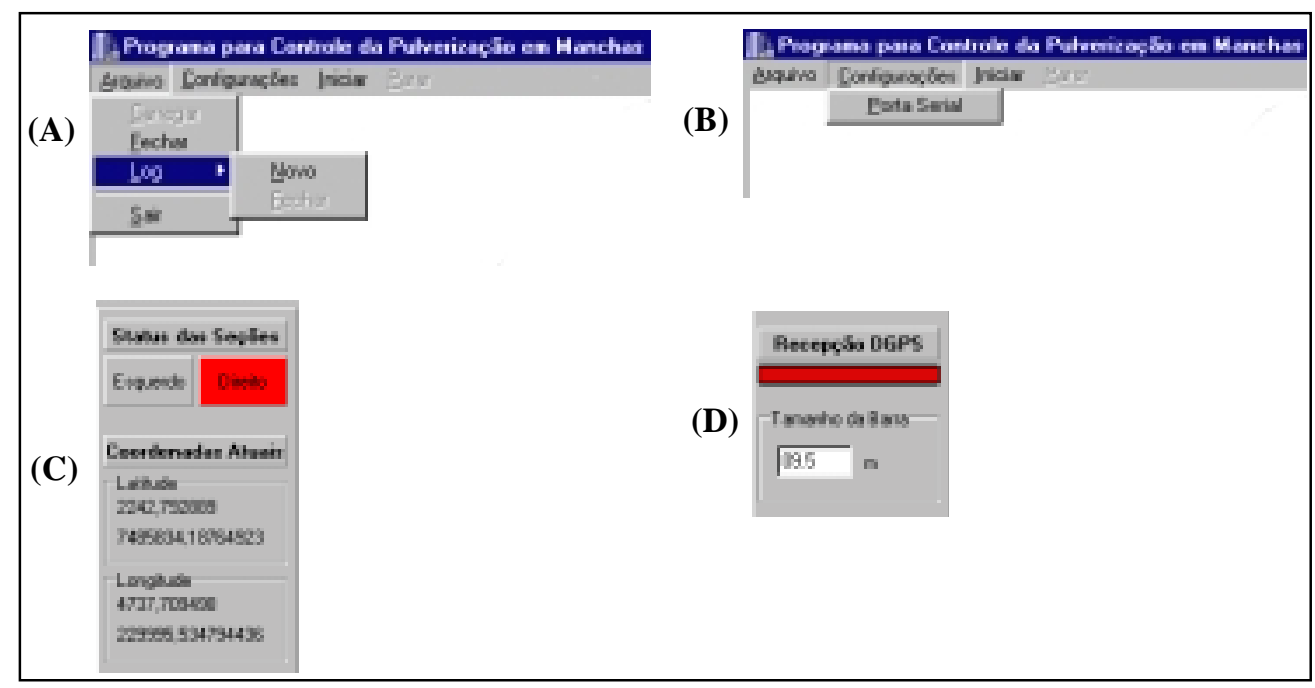

Figura 26 - Detalhes da tela do programa. Submenus de "Arquivo" (A), submenu de "Configurações" (B), Status das seções e Coordenadas atuais (C) e indicador de erros de recepção e definição do tamanho da barra de pulverização (D).

A Figura 26C ilustra o detalhe do campo "Status das Seções", onde é mostrado o status de funcionamento das válvulas solenóides. Neste exemplo, somente a válvula direita, e conseqüentemente a seção direita, estão acionados. O mesmo item mostra o detalhe do campo "Coordenadas Atuais", onde são impressas as latitudes e longitudes da localização do pulverizador no campo no formato geodésico e no formato UTM. A cada segundo este formulário é atualizado com uma nova posição enviada pelo DGPS. A Figura 26D detalha o indicador de perda de recepção dos sinais de GPS ou algum problema na recepção dos sinais de correção. A mesma Figura mostra também o campo de definição do tamanho da barra de pulverização. 


\subsection{Teste do sistema numa situação real de controle}

\subsubsection{Mapeamento das plantas daninhas}

De acordo com as imagens da área onde foi realizado o teste, mostradas na Figura 3 (no item 3.1.1), verifica-se que as infestações de plantas daninhas encontravamse bastante agregadas. O padrão de distribuição das plantas daninhas encontrado permitiu uma clara definição dos limites das manchas de infestação, o que favoreceu a execução da estratégia de mapeamento adotada. Em determinadas situações, a estratégia do georreferenciamento do perímetro das infestações pode ser considerada difícil e subjetiva, principalmente quando as infestações são altas e com grande número de espécies, resultando em erros na identificação dos limites das infestações. Entretanto, na situação encontrada, onde as infestações se apresentaram agregadas e muito pobres em diversidade de espécies, o mapeamento se tornou pouco subjetivo e eficaz. Este cenário se mostrou interessante para os objetivos propostos neste trabalho e é uma situação relativamente comum em áreas de reforma de canavial.

Ao longo do mapeamento, foram identificadas apenas três espécies de plantas daninhas com algum padrão de agregação: tiririca (Cyperus rotundus L.), cordade-viola (Ipomoea nil L.) e grama-seda (Cynodon dactylon L.). Todas as espécies estavam em estádio inicial de desenvolvimento (plântulas com 3 a $4 \mathrm{~cm}$ de altura).

A Figura 27 mostra os mapas das espécies infestantes e do perímetro do talhão. Nota-se que a maior parte das infestações mapeadas foi de tiririca. A tiririca é uma das plantas daninhas de mais difícil combate na cultura da cana-de-açúcar e requer altas doses de herbicida para que haja controle eficiente. As outras plantas daninhas encontradas, corda-de-viola e grama-seda, apresentaram pequenas manchas com um mínimo padrão de agregação e também algumas ocorrências esporádicas, sem nenhum padrão de agregação. 


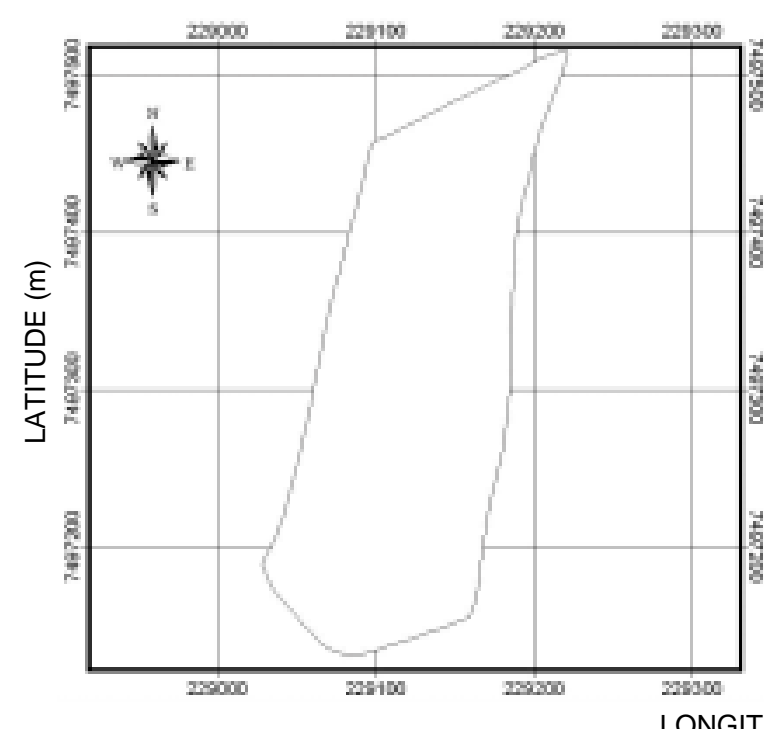

(A) Bordadura do talhão

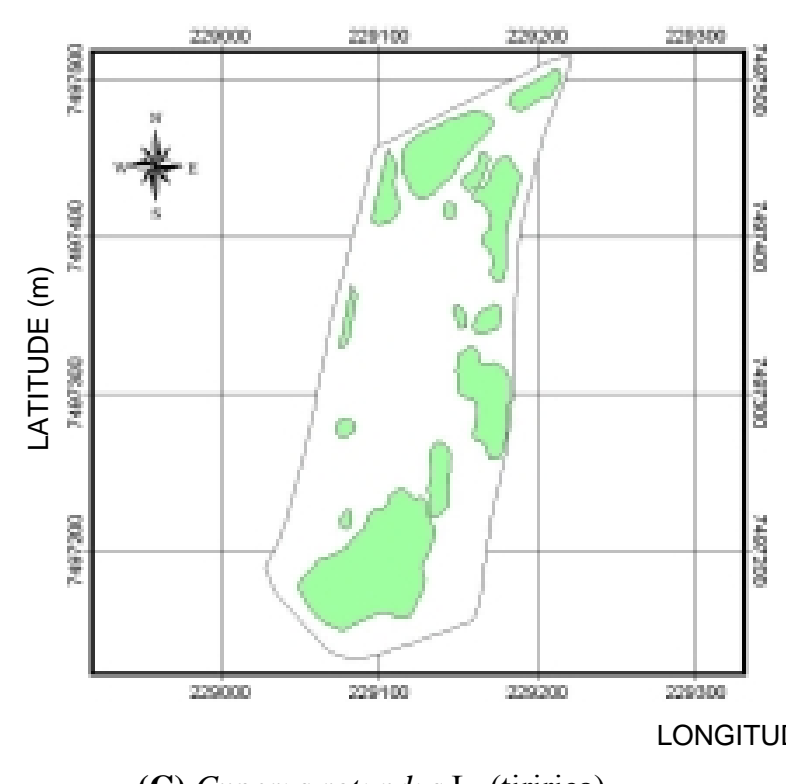

(C) Cyperus rotundus L. (tiririca)

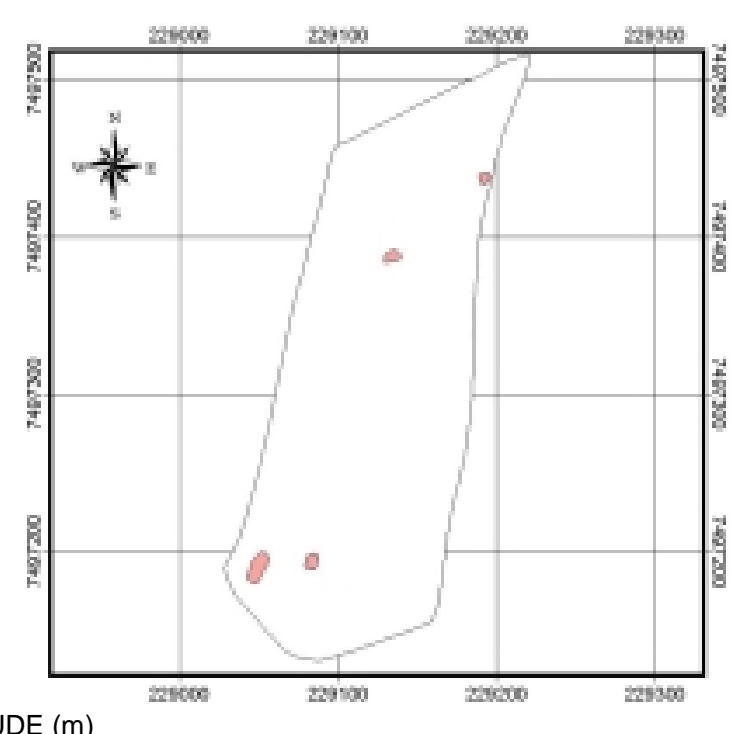

(B) Ipomoea nil L. (corda-de-viola)

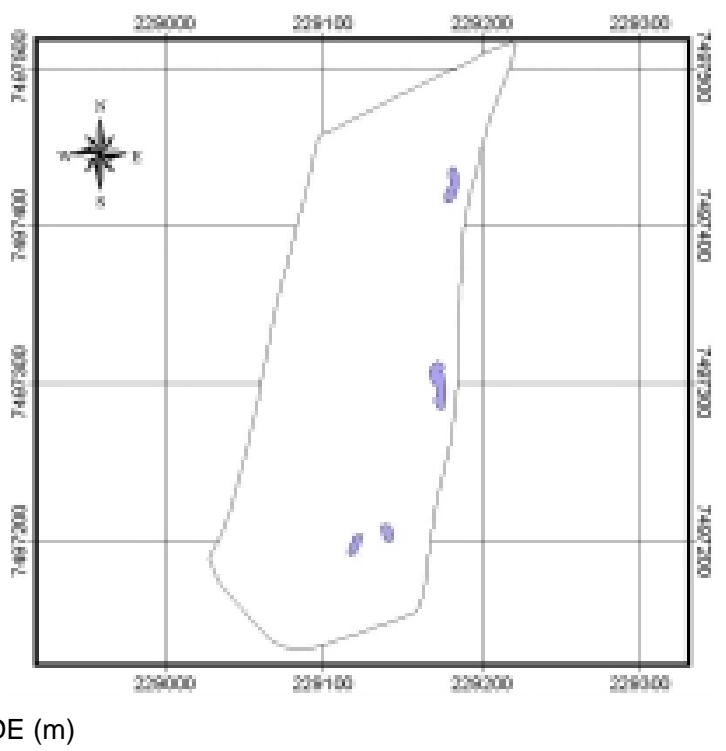

(D) Cynodon dactylon L. (grama-seda)

Figura 27 - Os quatro mapeamentos realizados na área do teste.

As manchas de tiririca totalizaram 1,02 ha, enquanto que as manchas de corda-de-viola e grama-seda totalizaram, juntas, 0,1 ha. Assim, aproximadamente $1 / 4$ do talhão estava infestado com algum tipo de planta daninha, comprovando os relatos de diversos autores de que a maioria das plantas infestantes ocorre de maneira heterogênea, 
em manchas agregadas (Gerhards et al., 1996; Nordmeyer et al., 1997; Green et al., 1997, entre outros).

A grade de $20 \times 20 \mathrm{~m}$ utilizada facilitou o mapeamento, pois evitou que alguma área fosse mapeada mais de uma vez, ou que deixasse de ser mapeada. Os três mapas de infestação foram sobrepostos no programa SSToolBox e o mapa de prescrição elaborado, conforme metodologia relatada. O mapa de prescrição, contendo as regiões onde a pulverização deveria ocorrer, é mostrado na Figura 28.

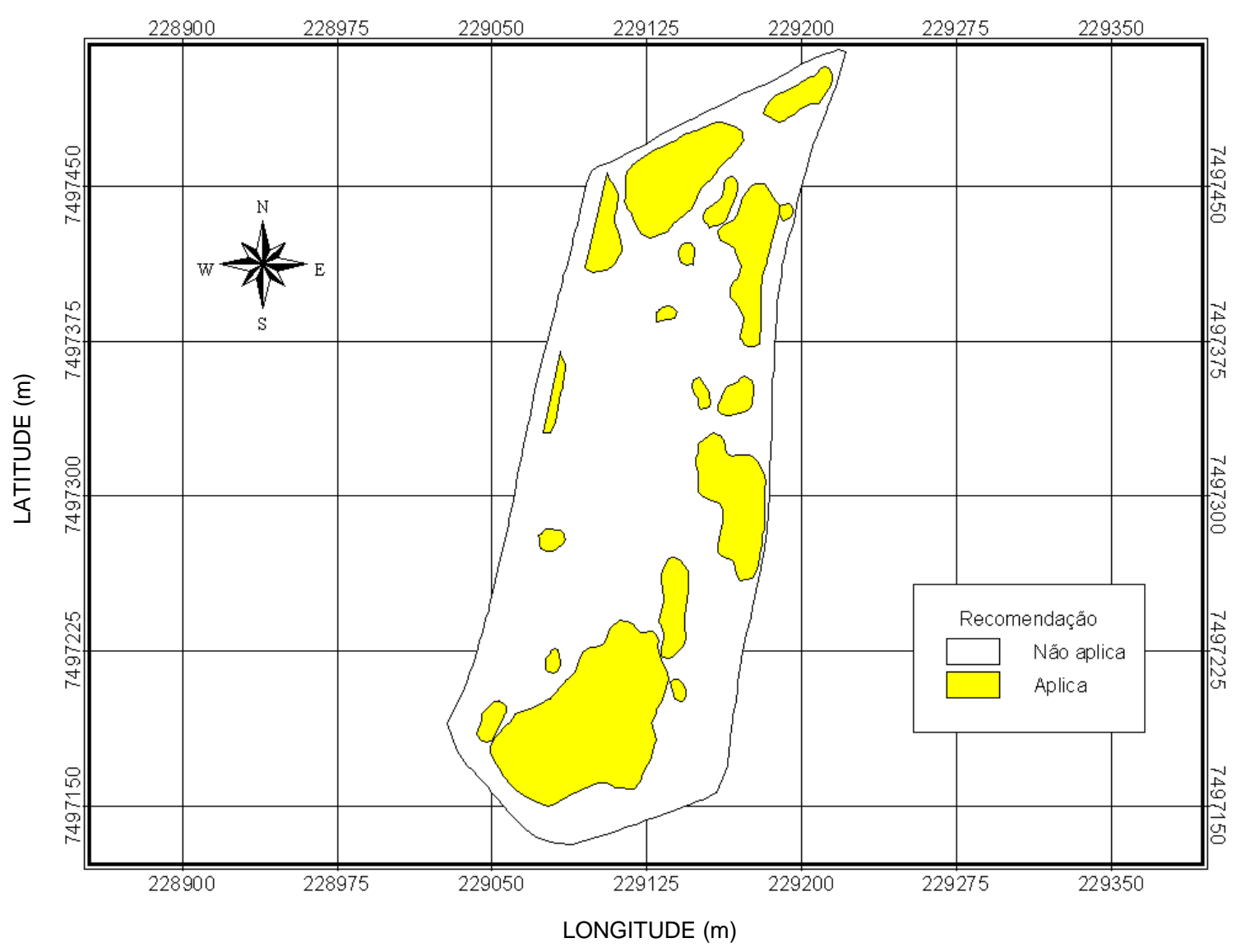

Figura 28 - Mapa de prescrição do talhão.

\subsubsection{A aplicação localizada}

Conforme relatado na metodologia, a velocidade de $1,1 \mathrm{~m} \cdot \mathrm{s}^{-1}\left(4,0 \mathrm{~km} \cdot \mathrm{h}^{-1}\right)$ foi mantida constante ao longo de todo trajeto. $\mathrm{O}$ volume de calda gasto na operação de 
pulverização foi de 250 L. O arquivo de registro da aplicação, listado no Anexo B, deu origem ao mapa da Figura 29.

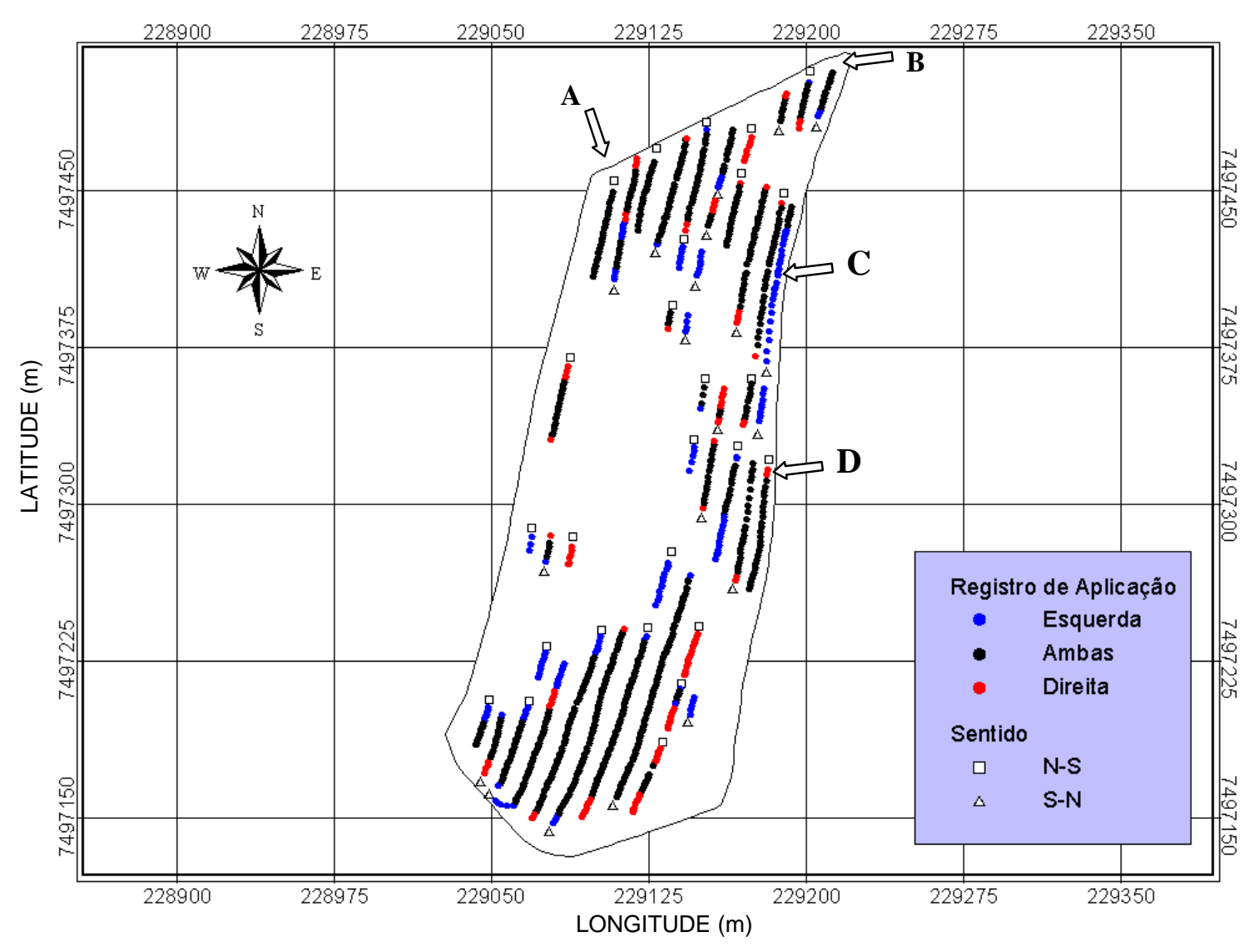

Figura 29 - Arquivo de registro da aplicação.

Cada ponto no mapa representa uma posição geográfica onde ocorreu o acionamento de alguma válvula presente no pulverizador. As cores, conforme a legenda, indicam as seções acionadas. Os quadrados e triângulos indicam o início de cada grupo de coordenadas e auxiliam na definição do sentido de deslocamento do trator. O ponto A é o local do início da pulverização e o ponto B o fim; o ponto $\mathrm{C}$ mostra um local onde houve excessiva sobreposição, em função do formato irregular do talhão (mais largo ao sul e estreito ao norte) e o ponto D mostra o início da única "linha morta" de todo o percurso. 
O gráfico da Figura 30 ilustra o número de pontos georreferenciados e o acionamento correspondente de cada uma das seções de barra.

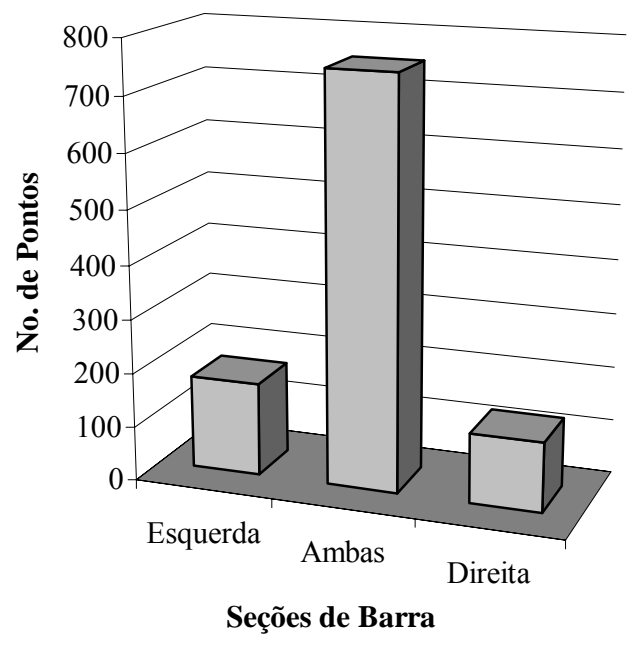

Figura 30 - Número de pontos onde houve acionamento das seções de barra.

Evidentemente, o número de pontos onde ambas seções foram acionadas é superior aos pontos onde houve o acionamento de uma única válvula. Entretanto, o intuito deste gráfico é mostrar que o controle independente das seções de barra foi bastante solicitado, uma vez que em cerca de 300 pontos (de um total de 1054) este acionamento foi executado (somando-se seções esquerda e direita). O gráfico da Figura 31 mostra os dados em porcentagem.

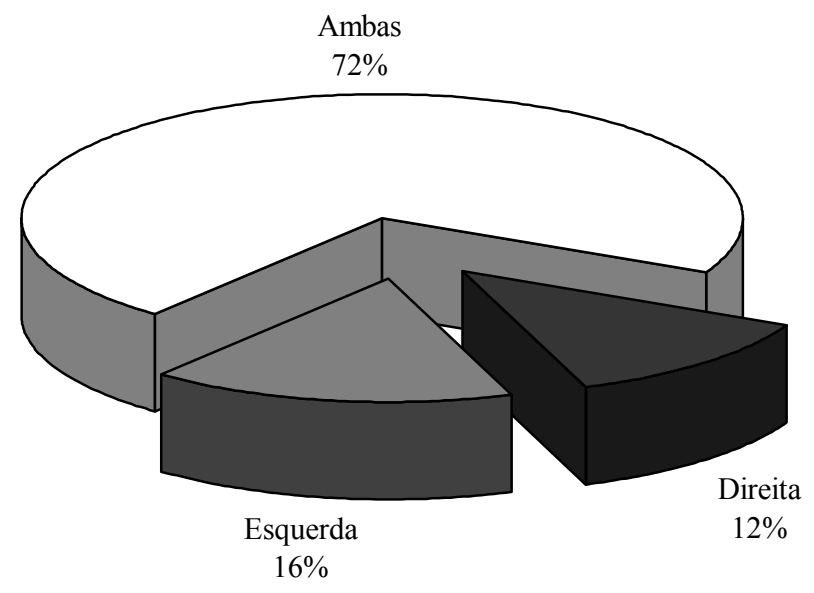

Figura 31 - Porcentagem dos pontos de acionamento das seções de barra. 
A Figura 31 mostra que em $28 \%$ dos pontos registrados houve o acionamento de apenas uma seção de barra, o que permitiu redução de herbicida, caso o controle fosse efetuado sobre a barra toda. Este fato justificou o desenvolvimento de uma rotina de cálculos implementada ao programa para o controle independente das seções e mostra que o aumento da resolução espacial do pulverizador resulta em maior economia de herbicida em operações de aplicação localizada, conforme relataram Gerhards et al., 1999.

\subsubsection{Avaliação dos resultados}

\subsubsection{Sobreposição do mapa de registro ao mapa de prescrição}

A Figura 32 mostra o arquivo de registro sobreposto ao mapa de prescrição, onde verificou-se que os alvos foram atingidos. A sobreposição do arquivo de registro ao mapa de prescrição mostrou que, quando o centro do trator encontrava-se no interior de uma mancha de infestação, ambas seções foram acionadas. Quando fora, o programa foi capaz de verificar se as extremidades da barra estavam sobre infestações, promovendo o acionamento somente dessas seções. Contudo, a confirmação do acerto aos alvos somente foi obtida pela identificação visual do controle e mapeamento das manchas não controladas. 


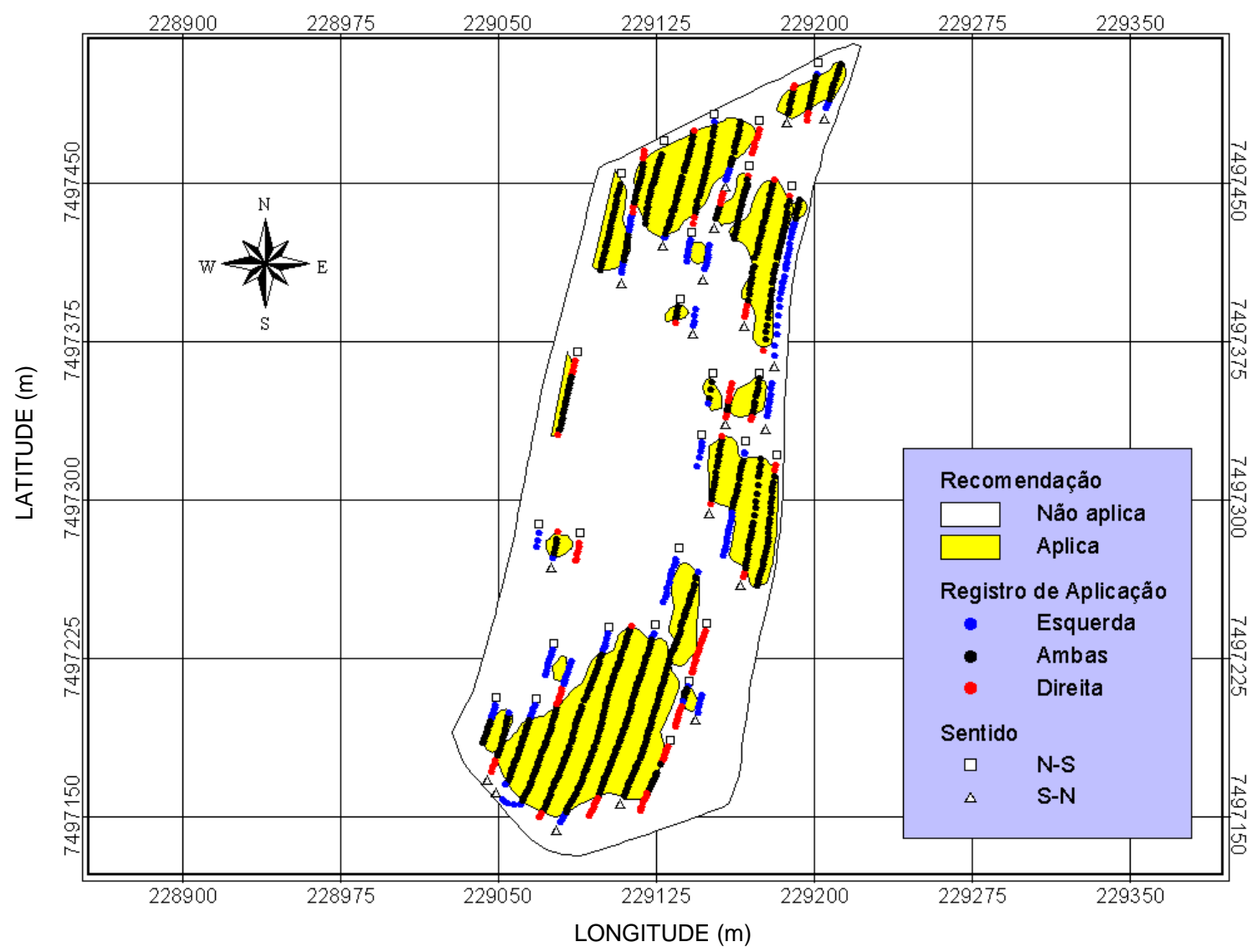

Figura 32 - Mapa de registro da aplicação sobreposto ao mapa de recomendação.

\subsubsection{Identificação visual do controle e mapeamento das manchas não controladas}

As imagens da Figura 33 mostram um mesmo local, antes e após o controle químico. O período de 30 dias foi suficiente para verificar a sua eficiência.

No mapeamento das manchas não controladas constatou-se uma falha de aplicação, resultante da perda de recepção do sinal do GPS ou do sinal de correção. Esta falha é mostrada na Figura 34. 


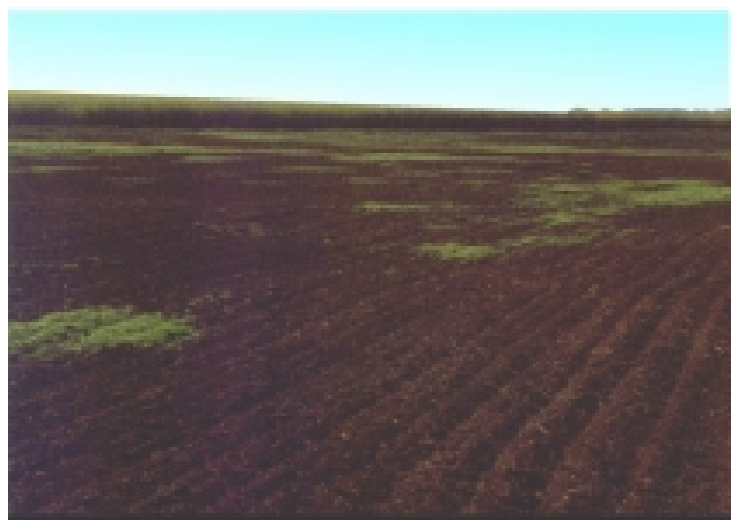

(A)

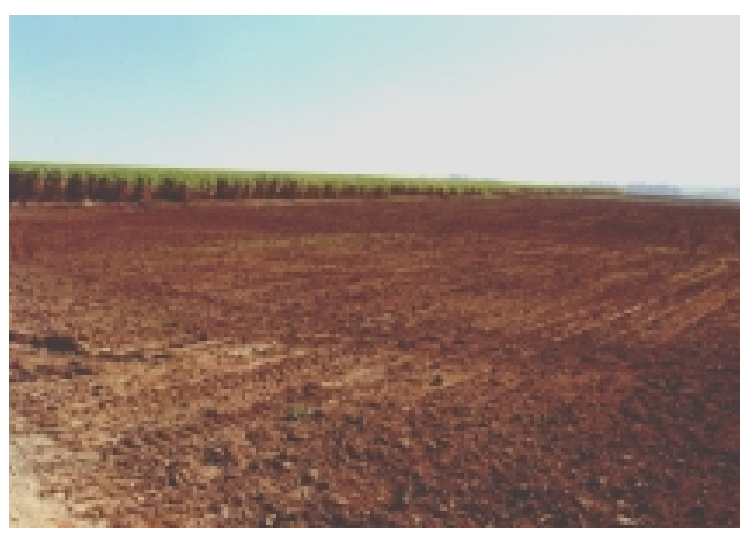

(B)

Figura 33 - Manchas de infestação antes (A) e após (B) o controle.

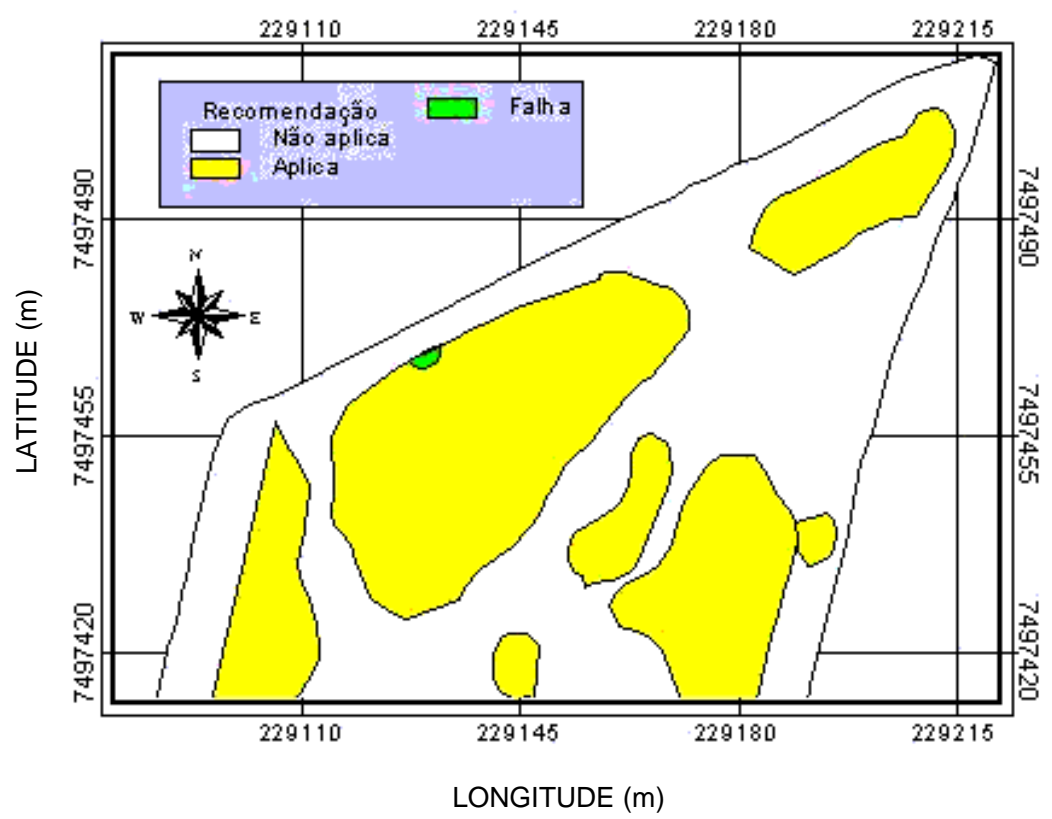

Figura 34 - Falha de aplicação.

Assim como relatado na descrição dos métodos, ao ocorrer uma perda de recepção, o programa considera o ponto anterior. Quando isto ocorre e o trator se encontra longe das bordas das manchas, este problema não causa falhas, pois o ponto anterior possui o mesmo comando das válvulas. Entretanto, se a perda de recepção ocorre próximo às bordas de uma mancha, falhas de aplicação podem acontecer, pois o 
ponto anterior pode ter um comando diferente das válvulas. Foi o que ocorreu no presente caso: a falha de recepção se deu no momento em que o trator entrava na mancha. Neste momento, o programa considerou o ponto anterior, quando o trator encontrava-se fora da mancha, realizando a manobra de cabeceira, com as duas válvulas desligadas. Utilizando este ponto anterior, as válvulas continuaram desligadas até que a recepção ser restabelecida, o que provocou a falha. Além disso, o indicador de perda de recepção foi aceso nesse momento, o que confirmou a causa da falha.

Esta foi a única falha decorrente de problemas de recepção e não foram encontradas falhas referentes ao tempo de atualização das informações de posicionamento, o que mostra que a bordadura de 1,5 $\mathrm{m}$ foi suficiente.

\subsubsection{Determinação da economia de herbicida}

Se a aplicação tivesse sido realizada em área total, o gasto com herbicida seria de:

Área total: 4,1 hectares

Dosagem do herbicida: 4,0 L.ha' ${ }^{-1}$

Quantidade de calda necessária: $820 \mathrm{~L}$

Consumo de herbicida $=4,1$ ha $x 4$ L.ha ${ }^{-1}=\mathbf{1 6 , 4} \mathbf{L}$

O consumo de herbicida obtido no teste foi determinado em função da quantidade de calda gasta:

Quantidade de calda por hectare: $200 \mathrm{~L}$

Quantidade de calda gasta na aplicação localizada: 250 L

$200 \mathrm{~L} \longrightarrow 4,0 \mathrm{~L}$ de herbicida

$250 \mathrm{~L} \longrightarrow x$ L de herbicida

$x=5,0 \mathrm{~L}$ 
Portanto, a redução alcançada foi de:

$$
100-\frac{5,0}{16,4} \times 100=\mathbf{6 9 , 5 2 \%}
$$

\subsection{Considerações Finais}

A redução alcançada de herbicida de quase $70 \%$ em comparação ao tratamento convencional evidencia que a aplicação localizada de herbicidas se mostra capaz de promover grandes reduções deste defensivo, conforme relataram Mortensen et al., 1995; Heisel et al., 1996b; entre outros. Entretanto, reduções elevadas como o presente caso somente são alcançadas em condições específicas. A situação encontrada na área do teste, onde as plantas daninhas mantinham alto padrão de agregação, com a formação de manchas bastante nítidas e áreas sem nenhuma infestação, pode ser considerada relativamente comum em campos de reforma de canavial. Alguns trabalhos realizados em clima temperado também relataram este tipo de situação (Lippert \& Wolak, 1999; Biller et al., 1997), com o predomínio de baixa diversidade de espécies. Contudo, esta situação nem sempre ocorre em situações de clima tropical e subtropical, com a predominância de grande diversidade de infestações, não sendo comum a existência de áreas isentas de qualquer planta daninha.

Estas observações não inviabilizam o uso da estratégia liga-desliga em outras situações diferentes da encontrada, por duas razões. A primeira delas se refere ao conceito de nível de dano econômico, que nem sempre é respeitado. Mesmo num campo que aparentemente esteja infestado por toda sua extensão, é possível que determinadas regiões estejam com infestações abaixo do nível de dano econômico, onde o controle químico não é justificado. Desta forma, a pulverização poderia ser confinada somente às áreas com infestação acima do nível de dano econômico. A segunda razão é a possibilidade de se realizar o controle por meio de duas operações de pulverização. Pode-se supor uma determinada área totalmente infestada, mas com regiões de maior e 
de menor densidade de infestação, onde poderiam ser empregadas duas doses diferentes: metade e total. O controle poderia ser feito por meio de uma primeira pulverização com metade da dose em área total, e uma segunda aplicação, novamente com metade da dose, de forma localizada, sobre as manchas de maior densidade de infestação. Assim, as manchas de maior densidade receberiam a dose total e o restante, a metade da dose. Evidentemente, este tipo de estratégia acarretaria num maior custo de maquinário e de mão-de-obra; contudo, este aumento de custos poderia ser coberto pela economia de herbicida alcançada. Cada caso deve ser analisado para que seja verificada a potencialidade de redução de herbicidas. Conforme relatado na revisão bibliográfica, Williams et al. (1998) utilizaram esta estratégia, obtendo reduções bastante significantes. Além disso, os autores verificaram que no ano posterior, as áreas que receberam metade da dose não apresentaram aumento na densidade de infestação.

Com relação à bordadura de segurança, pode-se dizer que é necessária não só para evitar as falhas de controle devidas ao tempo de atualização da informação de posicionamento, como também para evitar as falhas resultantes do erro de posicionamento do DGPS e do tempo de resposta do equipamento, embora este último não tenha sido um fator importante neste trabalho. Outra função da bordadura é prevenir falhas de controle devidas ao crescimento das infestações ao redor das manchas, o que pode ocorrer em situações onde o mapeamento e o controle são efetuados com grande intervalo de tempo.

Algumas considerações devem também ser feitas com relação ao programa desenvolvido. A metodologia empregada em seu desenvolvimento se mostrou eficiente e pode ser utilizada em outros estudos envolvendo a aplicação de defensivos em razões variáveis. Da mesma forma como a cor azul foi designada para demarcar no plano gráfico regiões onde a pulverização deveria ocorrer, outras cores poderiam ser empregadas para demarcar áreas com diferentes infestações e, conseqüentemente, diferentes dosagens. Além disso, seguindo-se a mesma metodologia empregada nesta versão, o programa poderia ser implementado para controlar um número maior de seções de barra, podendo aumentar ainda mais a resolução espacial do pulverizador. 


\section{CONCLUSÕES}

Um pulverizador convencional foi adaptado com válvulas solenóides e o controle da pulverização efetuado de forma automática, via um computador portátil, sem a intervenção do operador. $\mathrm{O}$ uso das válvulas solenóides permitiu rápida resposta do equipamento quando a pulverização foi solicitada.

A metodologia empregada no desenvolvimento do programa computacional para o controle das seções do pulverizador mostrou-se eficaz.

A metodologia empregada no mapeamento das plantas daninhas mostrouse eficiente e foi favorecida pelo alto padrão de agregação e reduzido número de espécies encontradas.

Os resultados do teste do sistema numa situação real de controle de plantas daninhas mostraram que o mesmo foi capaz de promover a aplicação localizada de herbicida em dose fixa, nas manchas de infestação mapeadas.

Os resultados mostraram que o sistema proposto permitiu uma redução do uso do herbicida.

O controle independente das seções de barra funcionou como o esperado e permitiu maior redução de herbicida. 


\section{ANEXOS}




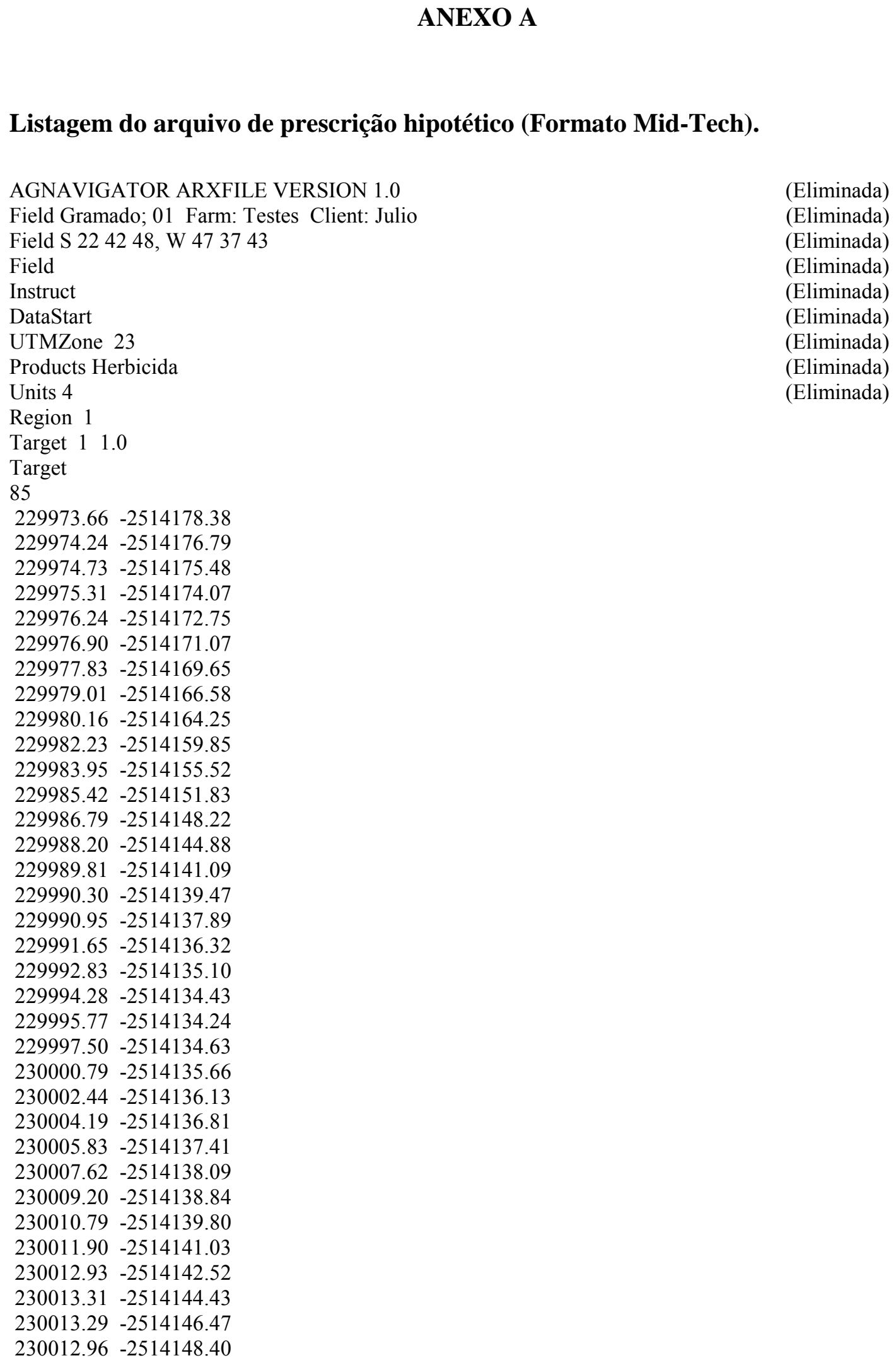


$230012.68-2514150.32$

$230012.31-2514152.22$

$230011.93-2514154.21$

$230011.49-2514156.12$

$230011.08-2514158.07$

$230010.74-2514160.05$

$230010.20-2514161.93$

$230009.96-2514164.10$

$230009.50-2514166.08$

$230009.09-2514168.09$

$230008.63-2514169.97$

$230008.39-2514172.07$

$230007.81-2514175.33$

$230007.49-2514177.16$

$230006.99-2514179.97$

$230006.48-2514182.21$

$230005.86-2514184.94$

$230005.22-2514187.76$

$230004.83-2514189.68$

$230004.35-2514191.62$

$230003.98-2514193.59$

$230003.44-2514195.73$

$230003.18-2514197.69$

$230002.86-2514199.57$

$230002.34-2514201.60$

$230001.01-2514205.45$

$230000.24-2514208.82$

$229999.11-2514212.96$

$229998.59-2514214.96$

$229997.53-2514216.83$

$229996.13-2514218.39$

$229993.77-2514219.72$

$229989.97-2514220.30$

$229978.96-2514217.41$

$229973.20-2514214.69$

$229968.85-2514211.17$

$229966.39-2514207.11$

$229965.38-2514203.53$

$229965.79-2514199.93$

$229966.13-2514198.10$

$229966.83-2514196.51$

$229967.39-2514194.94$

$229967.88-2514193.44$

$229968.52-2514191.96$

$229969.05-2514190.51$

$229969.58-2514189.05$

$229970.07-2514187.66$

$229970.55-2514186.31$

$229971.06-2514185.02$

$229971.75-2514182.70$

$229972.83-2514179.98$

Region 1

Target 12.0

Target 


\begin{abstract}
11
$229988.10-2514170.72$

$229992.84-2514172.44$

$229997.49-2514174.07$

$229995.76-2514178.71$

$229994.33-2514183.34$

$229992.60-2514188.26$

$229987.80-2514186.47$

$229983.07-2514184.77$

$229984.73-2514180.12$

$229986.38-2514175.28$

$229988.02-2514170.73$

DataEnd
\end{abstract}




\begin{abstract}
ANEXO B
Listagem do arquivo de registro, contendo as coordenadas dos locais onde houve acionamento das válvulas.
\end{abstract}

\author{
A = Ambas as Válvulas \\ $\mathrm{D}=$ Válvula Direita \\ $\mathrm{E}=$ Válvula Esquerda
}

\title{
LATITUDE, LONGITUDE, VÁLVULA
}

\begin{tabular}{|c|c|c|c|c|}
\hline 2236.49576 & 4738.10722 & A & 2236.55619 & 4738.12463 \\
\hline 2236.49699 & 4738.10755 & $\mathrm{~A}$ & 2236.55681 & 4738.12476 \\
\hline 2236.49815 & 4738.10789 & A & 2236.55802 & 4738.12509 \\
\hline 2236.49872 & 4738.10807 & A & 2236.55862 & 4738.12524 \\
\hline 36.49991 & 4738.10831 & A & 2236.55990 & 4738.12567 \\
\hline 36.50108 & 4738.10859 & A & 2236.58462 & 4738.13135 \\
\hline 36.50166 & 4738.10874 & A & 2236.58648 & 4738.13173 \\
\hline 36.50280 & 4738.10914 & A & 2236.58823 & 4738.13211 \\
\hline 236.50341 & 4738.10928 & A & 2236.62857 & 4738.14436 \\
\hline 236.50420 & 4738.10945 & A & 2236.62921 & 4738.14454 \\
\hline 236.50518 & 4738.10971 & A & 2236.62974 & 4738.14475 \\
\hline 236.50636 & 4738.10999 & A & 2236.63037 & 4738.14493 \\
\hline 236.50696 & 4738.11012 & A & 2236.63094 & 4738.14516 \\
\hline 36.50820 & 4738.11035 & A & 2236.63151 & 4738.14538 \\
\hline 236.50878 & 4738.11055 & A & 2236.63204 & 4738.14562 \\
\hline 236.50951 & 4738.11086 & A & 2236.63261 & 4738.14583 \\
\hline 236.51053 & 4738.11114 & A & 2236.63323 & 4738.14605 \\
\hline 36.51114 & 4738.11125 & A & 2236.63378 & 4738.14626 \\
\hline 236.51172 & 4738.11145 & A & 2236.63437 & 4738.14647 \\
\hline 236.51293 & 4738.11178 & A & 2236.63492 & 4738.14659 \\
\hline 236.51349 & 4738.11189 & A & 2236.63548 & 4738.14684 \\
\hline 236.51465 & 4738.11220 & A & 2236.63605 & 4738.14711 \\
\hline 236.51520 & 4738.11246 & A & 2236.63661 & 4738.14733 \\
\hline 236.51581 & 4738.11258 & A & 2236.63721 & 4738.14761 \\
\hline 236.51637 & 4738.11279 & A & 2236.63779 & 4738.14779 \\
\hline 236.51757 & 4738.11312 & A & 2236.63832 & 4738.14805 \\
\hline 2236.54096 & 4738.12040 & $\mathrm{D}$ & 2236.64556 & 4738.14590 \\
\hline 2236.54216 & 4738.12073 & $\mathrm{D}$ & 2236.64441 & 4738.14535 \\
\hline 236.54327 & 4738.12107 & $\mathrm{D}$ & 2236.64329 & 4738.14486 \\
\hline 236.54387 & 4738.12129 & $\mathrm{D}$ & 2236.64274 & 4738.14466 \\
\hline 236.54445 & 4738.12156 & $\mathrm{D}$ & 2236.64164 & 4738.14411 \\
\hline 2236.54504 & 4738.12172 & A & 2236.64104 & 4738.14388 \\
\hline 2236.54555 & 4738.12191 & A & 2236.64048 & 4738.14365 \\
\hline 2236.54646 & 4738.12214 & A & 2236.63990 & 4738.14341 \\
\hline 2236.54738 & 4738.12228 & A & 2236.63875 & 4738.14302 \\
\hline 2236.54800 & 4738.12242 & A & 2236.63755 & 4738.14263 \\
\hline 2236.54859 & 4738.12260 & A & 2236.63697 & 4738.14245 \\
\hline 2236.54917 & 4738.12276 & A & 2236.63642 & 4738.14220 \\
\hline 2236.55036 & 4738.12310 & A & 2236.63526 & 4738.14186 \\
\hline 2236.55155 & 4738.12338 & A & 2236.63464 & 4738.14171 \\
\hline 2236.55213 & 4738.12355 & A & 2236.63349 & 4738.14144 \\
\hline 2236.55330 & 4738.12375 & A & 2236.63290 & 4738.14122 \\
\hline 2236.55447 & 4738.12410 & A & 2236.63231 & 4738.14106 \\
\hline 2236.55563 & 4738.12440 & A & 2236.63169 & 4738.14090 \\
\hline
\end{tabular}

\begin{tabular}{|c|c|}
\hline 2236.63051 & 4738.14058 \\
\hline 2236.59110 & 4738.12758 \\
\hline 2236.58980 & 4738.12718 \\
\hline 236.58855 & 4738.12688 \\
\hline 236.58734 & 4738.12665 \\
\hline 36.58615 & 4738.12643 \\
\hline 36.58433 & 4738.12612 \\
\hline 36.51832 & 4738.10725 \\
\hline 36.51771 & 4738.10716 \\
\hline 36.51655 & 4738.10686 \\
\hline 36.51597 & 4738.10668 \\
\hline 36.51510 & 4738.10654 \\
\hline 36.51422 & 4738.10631 \\
\hline 36.51302 & 4738.10604 \\
\hline 236.51184 & 4738.10581 \\
\hline 36.51057 & 4738.10563 \\
\hline 36.50937 & 4738.10545 \\
\hline 36.50874 & 4738.10535 \\
\hline 236.50757 & 4738.10502 \\
\hline 236.50700 & 4738.10489 \\
\hline 36.50609 & 4738.10468 \\
\hline 36.50521 & 4738.10451 \\
\hline 36.50460 & 4738.10441 \\
\hline 36.50402 & 4738.10426 \\
\hline 236.50286 & 4738.10389 \\
\hline 36.50167 & 4738.10364 \\
\hline 36.50110 & 4738.10346 \\
\hline 36.50045 & 4738.10337 \\
\hline 236.49992 & 4738.10315 \\
\hline 36.49872 & 4738.10287 \\
\hline 36.49752 & 4738.10252 \\
\hline 36.49691 & 4738.10237 \\
\hline 36.49635 & 4738.10219 \\
\hline 236.49575 & 4738.10201 \\
\hline 236.49520 & 4738.10180 \\
\hline 236.49431 & 4738.10151 \\
\hline 236.49340 & 4738.10130 \\
\hline 2236.49282 & 4738.10116 \\
\hline 2236.49158 & 4738.10095 \\
\hline 2236.49049 & 4738.10075 \\
\hline 2236.48916 & 4738.10061 \\
\hline 2236.48822 & 4738.10050 \\
\hline 236.48728 & 4738.10043 \\
\hline 236.48621 & 4738.09533 \\
\hline
\end{tabular}




\begin{tabular}{|c|c|}
\hline 236.48717 & 4738.09532 \\
\hline 2236.48829 & 4738.09545 \\
\hline 2236.48936 & 4738.09596 \\
\hline 236.48995 & 4738.09612 \\
\hline 236.49053 & 4738.09631 \\
\hline 236.49114 & 4738.09657 \\
\hline 236.49171 & 4738.09679 \\
\hline 236.49231 & 4738.09698 \\
\hline 36.49346 & 4738.09730 \\
\hline 236.49401 & 4738.09749 \\
\hline 236.49460 & 4738.09769 \\
\hline 236.49521 & 4738.09789 \\
\hline 36.49581 & 4738.09816 \\
\hline 36.49634 & 4738.09843 \\
\hline 236.49753 & 4738.09873 \\
\hline 236.49819 & 4738.09890 \\
\hline 236.49932 & 4738.09915 \\
\hline 36.50040 & 4738.09949 \\
\hline 236.50165 & 4738.09967 \\
\hline 236.50224 & 4738.09980 \\
\hline 236.50346 & 4738.10003 \\
\hline 36.50458 & 4738.10025 \\
\hline 236.50600 & 4738.10033 \\
\hline 2236.58723 & 4738.12023 \\
\hline 2236.58844 & 4738.12040 \\
\hline 2236.58961 & 4738.12078 \\
\hline 236.59019 & 4738.12093 \\
\hline 236.59136 & 4738.12125 \\
\hline 2236.59190 & 4738.12135 \\
\hline 2236.61467 & 4738.12827 \\
\hline 2236.61531 & 4738.12850 \\
\hline 2236.61584 & 4738.12864 \\
\hline 2236.61645 & 4738.12881 \\
\hline 2236.61728 & 4738.12909 \\
\hline 2236.61816 & 4738.12947 \\
\hline 2236.61878 & 4738.12964 \\
\hline 2236.61997 & 4738.13005 \\
\hline 2236.62090 & 4738.13030 \\
\hline 2236.62861 & 4738.13334 \\
\hline 2236.62978 & 4738.13386 \\
\hline 2236.63035 & 4738.13402 \\
\hline 2236.63088 & 4738.13436 \\
\hline 2236.63149 & 4738.13457 \\
\hline 2236.63202 & 4738.13482 \\
\hline 2236.63264 & 4738.13500 \\
\hline 2236.63322 & 4738.13528 \\
\hline 2236.63374 & 4738.13553 \\
\hline 2236.63431 & 4738.13576 \\
\hline 2236.63492 & 4738.13593 \\
\hline 2236.63549 & 4738.13614 \\
\hline 2236.63605 & 4738.13638 \\
\hline 2236.63663 & 4738.13660 \\
\hline 2236.63720 & 4738.13681 \\
\hline 2236.63781 & 4738.13709 \\
\hline 2236.63839 & 4738.13722 \\
\hline 2236.63899 & 4738.13748 \\
\hline 2236.63951 & 4738.13772 \\
\hline 2236.64011 & 4738.13792 \\
\hline 2236.64065 & 4738.13820 \\
\hline & 4738.13850 \\
\hline
\end{tabular}

$\begin{array}{lll}2236.64239 & 4738.13886 & \mathrm{~A} \\ 2236.64295 & 4738.13913 & \mathrm{~A} \\ 2236.64349 & 4738.13938 & \mathrm{~A} \\ 2236.64405 & 4738.13961 & \mathrm{~A} \\ 2236.64463 & 4738.13986 & \mathrm{~A} \\ 2236.64520 & 4738.14011 & \mathrm{~A} \\ 2236.64581 & 4738.14033 & \mathrm{~A} \\ 2236.64639 & 4738.14057 & \mathrm{~A} \\ 2236.64699 & 4738.14076 & \mathrm{~A} \\ 2236.64756 & 4738.14101 & \mathrm{~A} \\ 2236.64815 & 4738.14132 & \mathrm{~A} \\ 2236.64879 & 4738.14192 & \mathrm{E} \\ 2236.65265 & 4738.14291 & \mathrm{E} \\ 2236.65361 & 4738.14215 & \mathrm{E} \\ 2236.65387 & 4738.14151 & \mathrm{E} \\ 2236.65428 & 4738.13968 & \mathrm{E} \\ 2236.65403 & 4738.13804 & \mathrm{E} \\ 2236.65374 & 4738.13771 & \mathrm{E} \\ 2236.65330 & 4738.13737 & \mathrm{~A} \\ 2236.65269 & 4738.13706 & \mathrm{~A} \\ 2236.65214 & 4738.13676 & \mathrm{~A} \\ 2236.636 .636 \\ 2236.636\end{array}$

\begin{tabular}{|c|c|}
\hline 236.62461 & 4738.1257 \\
\hline 2236.62345 & 4738.12528 \\
\hline 2236.62286 & 4738.12503 \\
\hline 236.62230 & 4738.12484 \\
\hline 236.62176 & 4738.12466 \\
\hline 236.62118 & 4738.12441 \\
\hline 236.62058 & 4738.12420 \\
\hline 236.61919 & 4738.12375 \\
\hline 2236.61833 & 4738.12340 \\
\hline 2236.61748 & 4738.12305 \\
\hline 2236.50975 & 4738.09507 \\
\hline 236.50916 & 4738.09489 \\
\hline 2236.50862 & 4738.09468 \\
\hline 2236.50750 & 4738.09433 \\
\hline 2236.50692 & 4738.09418 \\
\hline 2236.50642 & 4738.09391 \\
\hline 2236.50584 & 4738.09377 \\
\hline 2236.50531 & 4738.09357 \\
\hline 2236.50474 & 4738.09340 \\
\hline 2236.50419 & 4738.09317 \\
\hline 2236.50298 & 4738.09292 \\
\hline 2236.50239 & 4738.09269 \\
\hline 2236.50182 & 4738.09253 \\
\hline 2236.50067 & 4738.09226 \\
\hline 2236.50010 & 4738.09206 \\
\hline 2236.49897 & 4738.09176 \\
\hline 2236.49837 & 4738.09154 \\
\hline 2236.49776 & 4738.09142 \\
\hline 2236.49662 & 4738.09105 \\
\hline 2236.49603 & 4738.09087 \\
\hline 2236.49547 & 4738.09065 \\
\hline 2236.49489 & 4738.09047 \\
\hline 2236.49430 & 4738.09029 \\
\hline 2236.49256 & 4738.08979 \\
\hline 2236.49198 & 4738.08958 \\
\hline 2236.49141 & 4738.08937 \\
\hline 2236.49082 & 4738.08920 \\
\hline 2236.49029 & 4738.08904 \\
\hline 2236.48911 & 4738.08866 \\
\hline 2236.48858 & 4738.08844 \\
\hline 2236.48803 & 4738.08827 \\
\hline 2236.48743 & 4738.08810 \\
\hline 2236.48656 & 4738.08777 \\
\hline 2236.48572 & 4738.08756 \\
\hline 2236.48451 & 4738.08733 \\
\hline 2236.48388 & 4738.08717 \\
\hline 2236.48274 & 4738.08688 \\
\hline 2236.48213 & 4738.08684 \\
\hline 2236.48017 & 4738.08117 \\
\hline 2236.48133 & 4738.08127 \\
\hline 2236.48269 & 4738.08147 \\
\hline 2236.48352 & 4738.08161 \\
\hline 2236.48529 & 4738.08193 \\
\hline 2236.48589 & 4738.08212 \\
\hline 2236.48701 & 4738.08233 \\
\hline 2236.48821 & 4738.08265 \\
\hline 2236.48879 & 4738.08278 \\
\hline 2236.48936 & 4738.08291 \\
\hline 2236.49056 & 4738.08314 \\
\hline & \\
\hline
\end{tabular}




\begin{tabular}{|c|c|}
\hline 236.49227 & 4738.08363 \\
\hline 2236.49343 & 4738.08394 \\
\hline 2236.49402 & 4738.08409 \\
\hline 236.49460 & 4738.08429 \\
\hline 236.49516 & 4738.08446 \\
\hline 36.49576 & 4738.08467 \\
\hline 36.49660 & 4738.08499 \\
\hline 236.49747 & 4738.08521 \\
\hline 36.49805 & 4738.08535 \\
\hline 236.49924 & 4738.08575 \\
\hline 236.50042 & 4738.08626 \\
\hline 236.50156 & 4738.08650 \\
\hline 36.50215 & 4738.08664 \\
\hline 36.50334 & 4738.08690 \\
\hline 236.50453 & 4738.08709 \\
\hline 2236.50624 & 4738.08734 \\
\hline 2236.51046 & 4738.08838 \\
\hline 36.51108 & 4738.08852 \\
\hline 236.51163 & 4738.08872 \\
\hline 236.51282 & 4738.08900 \\
\hline 236.51343 & 4738.08911 \\
\hline 236.51458 & 4738.08936 \\
\hline 236.51579 & 4738.08953 \\
\hline 2236.52746 & 4738.09208 \\
\hline 2236.52862 & 4738.09232 \\
\hline 2236.52980 & 4738.09263 \\
\hline 236.53041 & 4738.09272 \\
\hline 236.53154 & 4738.09296 \\
\hline 2236.61083 & 4738.11282 \\
\hline 2236.61201 & 4738.11312 \\
\hline 2236.61313 & 4738.11346 \\
\hline 2236.61377 & 4738.11364 \\
\hline 2236.61428 & 4738.11393 \\
\hline 2236.61489 & 4738.11410 \\
\hline 2236.61599 & 4738.11462 \\
\hline 2236.61652 & 4738.11486 \\
\hline 2236.61766 & 4738.11524 \\
\hline 2236.61826 & 4738.11541 \\
\hline 2236.61907 & 4738.11573 \\
\hline 2236.61997 & 4738.11605 \\
\hline 2236.62053 & 4738.11628 \\
\hline 2236.62109 & 4738.11652 \\
\hline 2236.62159 & 4738.11681 \\
\hline 2236.62211 & 4738.11707 \\
\hline 2236.62270 & 4738.11733 \\
\hline 2236.62332 & 4738.11757 \\
\hline 2236.62387 & 4738.11782 \\
\hline 2236.62438 & 4738.11808 \\
\hline 2236.62492 & 4738.11839 \\
\hline 2236.62545 & 4738.11868 \\
\hline 2236.62659 & 4738.11915 \\
\hline 2236.62775 & 4738.11979 \\
\hline 2236.62933 & 4738.12030 \\
\hline 2236.62992 & 4738.12047 \\
\hline 2236.63053 & 4738.12079 \\
\hline 2236.63098 & 4738.12109 \\
\hline 2236.63156 & 4738.12131 \\
\hline 2236.63215 & 4738.12150 \\
\hline 2236.63274 & 4738.12173 \\
\hline & 4738.12193 \\
\hline
\end{tabular}

\begin{tabular}{|c|c|}
\hline 236.63384 & 4738.12220 \\
\hline 2236.63441 & 4738.12238 \\
\hline 236.63556 & 4738.12270 \\
\hline 236.63619 & 4738.12288 \\
\hline 236.63729 & 4738.12318 \\
\hline 236.63788 & 4738.12329 \\
\hline 36.63842 & 4738.12354 \\
\hline 236.63952 & 4738.12402 \\
\hline 36.64012 & 4738.12424 \\
\hline 236.64068 & 4738.12453 \\
\hline 36.64126 & 4738.12473 \\
\hline 236.64178 & 4738.12497 \\
\hline 236.64237 & 4738.12522 \\
\hline 2236.64292 & 4738.12545 \\
\hline 2236.64347 & 4738.12571 \\
\hline 2236.64402 & 4738.12595 \\
\hline 2236.64456 & 4738.12621 \\
\hline 2236.64516 & 4738.12641 \\
\hline 2236.64570 & 4738.12665 \\
\hline 2236.64622 & 4738.12692 \\
\hline 2236.64678 & 4738.12720 \\
\hline 2236.64730 & 4738.12747 \\
\hline 2236.64782 & 4738.12775 \\
\hline 2236.64836 & 4738.12803 \\
\hline 2236.64892 & 4738.12833 \\
\hline 2236.64948 & 4738.12856 \\
\hline 2236.65053 & 4738.12903 \\
\hline 2236.65161 & 4738.12953 \\
\hline 2236.65216 & 4738.12974 \\
\hline 2236.65269 & 4738.13002 \\
\hline 2236.65323 & 4738.13024 \\
\hline 2236.65378 & 4738.13053 \\
\hline 2236.65434 & 4738.13082 \\
\hline 2236.65489 & 4738.13113 \\
\hline 2236.65543 & 4738.13150 \\
\hline 2236.65596 & 4738.13178 \\
\hline 2236.65651 & 4738.13208 \\
\hline 2236.65708 & 4738.13238 \\
\hline 2236.65762 & 4738.13270 \\
\hline 2236.65890 & 4738.12682 \\
\hline 2236.65781 & 4738.12622 \\
\hline 2236.65727 & 4738.12592 \\
\hline 2236.65672 & 4738.12560 \\
\hline 2236.65625 & 4738.12523 \\
\hline 2236.65568 & 4738.12495 \\
\hline 2236.65514 & 4738.12460 \\
\hline 2236.65407 & 4738.12399 \\
\hline 2236.65351 & 4738.12365 \\
\hline 2236.65299 & 4738.12332 \\
\hline 2236.65243 & 4738.12303 \\
\hline 2236.65192 & 4738.12270 \\
\hline 2236.65138 & 4738.12235 \\
\hline 2236.65032 & 4738.12175 \\
\hline 2236.64978 & 4738.12151 \\
\hline 2236.64923 & 4738.12119 \\
\hline 2236.64865 & 4738.12090 \\
\hline 2236.64643 & 4738.11993 \\
\hline 2236.64766 & 4738.12051 \\
\hline 2236.64590 & 4738.11966 \\
\hline & 4738110 \\
\hline
\end{tabular}

\begin{tabular}{|c|c|}
\hline 36.64479 & 4738.11919 \\
\hline 2236.64420 & 4738.11896 \\
\hline 2236.64363 & 4738.11873 \\
\hline 36.64311 & 4738.11848 \\
\hline 36.64255 & 4738.11825 \\
\hline 36.64198 & 4738.11799 \\
\hline 236.64141 & 4738.11775 \\
\hline 36.64026 & 4738.11733 \\
\hline 36.63972 & 4738.11710 \\
\hline 36.63826 & 4738.11645 \\
\hline 236.63695 & 4738.11602 \\
\hline 2236.63577 & 4738.11562 \\
\hline 2236.63518 & 4738.11544 \\
\hline 236.63462 & 4738.11529 \\
\hline 36.63404 & 4738.11509 \\
\hline 236.63351 & 4738.11491 \\
\hline 236.63233 & 4738.11466 \\
\hline 2236.63175 & 4738.11448 \\
\hline 2236.63053 & 4738.11422 \\
\hline 236.62936 & 4738.11394 \\
\hline 36.62878 & 4738.11380 \\
\hline 2236.62763 & 4738.11349 \\
\hline 2236.62644 & 4738.11316 \\
\hline 2236.62532 & 4738.11282 \\
\hline 236.62472 & 4738.11264 \\
\hline 2236.62415 & 4738.11246 \\
\hline 2236.62329 & 4738.11207 \\
\hline 2236.62244 & 4738.11178 \\
\hline 2236.62185 & 4738.11158 \\
\hline 2236.62132 & 4738.11120 \\
\hline 2236.62022 & 4738.11083 \\
\hline 2236.61962 & 4738.11056 \\
\hline 2236.61910 & 4738.11033 \\
\hline 2236.61858 & 4738.11009 \\
\hline 2236.61801 & 4738.10984 \\
\hline 2236.61741 & 4738.10958 \\
\hline 2236.61644 & 4738.10936 \\
\hline 2236.61549 & 4738.10896 \\
\hline 2236.61445 & 4738.10848 \\
\hline 2236.61348 & 4738.10809 \\
\hline 2236.61291 & 4738.10789 \\
\hline 2236.61230 & 4738.10769 \\
\hline 2236.61172 & 4738.10747 \\
\hline 2236.61116 & 4738.10724 \\
\hline 2236.61056 & 4738.10702 \\
\hline 2236.61001 & 4738.10682 \\
\hline 2236.60943 & 4738.10656 \\
\hline 2236.60890 & 4738.10630 \\
\hline 2236.53247 & 4738.08799 \\
\hline 2236.53133 & 4738.08777 \\
\hline 2236.52980 & 4738.08762 \\
\hline 2236.52821 & 4738.08730 \\
\hline 2236.51793 & 4738.08443 \\
\hline 2236.51734 & 4738.08423 \\
\hline 2236.51617 & 4738.08398 \\
\hline 2236.51497 & 4738.08366 \\
\hline 2236.51435 & 4738.08356 \\
\hline 2236.51292 & 4738.08332 \\
\hline 2236.51165 & 4738.08316 \\
\hline & \\
\hline
\end{tabular}




\begin{tabular}{|c|c|}
\hline 2236.50389 & 4738.08077 \\
\hline 2236.50330 & 4738.08061 \\
\hline 2236.50272 & 4738.08041 \\
\hline 236.50216 & 4738.08022 \\
\hline 236.50097 & 4738.07985 \\
\hline 236.50041 & 4738.07972 \\
\hline 236.49983 & 4738.07954 \\
\hline 236.49925 & 4738.07933 \\
\hline 2236.49864 & 4738.07917 \\
\hline 2236.49514 & 4738.07818 \\
\hline 236.49457 & 4738.07795 \\
\hline 236.49401 & 4738.07777 \\
\hline 236.49352 & 4738.07758 \\
\hline 2236.49294 & 4738.07739 \\
\hline 2236.49241 & 4738.07720 \\
\hline 36.49126 & 4738.07686 \\
\hline 236.49068 & 4738.07667 \\
\hline 236.49010 & 4738.07646 \\
\hline 2236.48953 & 4738.07632 \\
\hline 2236.48780 & 4738.07583 \\
\hline 236.48664 & 4738.07553 \\
\hline 236.48603 & 4738.07531 \\
\hline 2236.48546 & 4738.07517 \\
\hline 2236.48487 & 4738.07502 \\
\hline 2236.48370 & 4738.07466 \\
\hline 2236.48311 & 4738.07447 \\
\hline 2236.48252 & 4738.07431 \\
\hline 2236.48133 & 4738.07400 \\
\hline 2236.48017 & 4738.07364 \\
\hline 2236.48225 & 4738.06874 \\
\hline 2236.48346 & 4738.06913 \\
\hline 2236.48461 & 4738.06950 \\
\hline 2236.48571 & 4738.06992 \\
\hline 2236.48685 & 4738.07024 \\
\hline 2236.48745 & 4738.07039 \\
\hline 2236.48840 & 4738.07066 \\
\hline 2236.49413 & 4738.07193 \\
\hline 2236.49515 & 4738.07223 \\
\hline 2236.49629 & 4738.07246 \\
\hline 2236.49746 & 4738.07277 \\
\hline 2236.49807 & 4738.07292 \\
\hline 2236.49863 & 4738.07314 \\
\hline 2236.49921 & 4738.07328 \\
\hline 2236.49978 & 4738.07348 \\
\hline 2236.50058 & 4738.07376 \\
\hline 2236.50157 & 4738.07398 \\
\hline 2236.50212 & 4738.07414 \\
\hline 2236.50328 & 4738.07449 \\
\hline 2236.50383 & 4738.07469 \\
\hline 2236.50464 & 4738.07488 \\
\hline 2236.50563 & 4738.07501 \\
\hline 2236.50683 & 4738.07530 \\
\hline 2236.50742 & 4738.07546 \\
\hline 2236.50855 & 4738.07579 \\
\hline 2236.50921 & 4738.07593 \\
\hline 2236.51037 & 4738.07619 \\
\hline 2236.54695 & 4738.08320 \\
\hline 2236.54876 & 4738.08352 \\
\hline 2236.55110 & 4738.08398 \\
\hline & \\
\hline
\end{tabular}

\begin{tabular}{|c|c|}
\hline 236.56230 & 4738.08599 \\
\hline 2236.56344 & 4738.08622 \\
\hline 236.56461 & 4738.08647 \\
\hline 236.56639 & 4738.08696 \\
\hline 236.56843 & 4738.08762 \\
\hline 236.59187 & 4738.09384 \\
\hline 36.59244 & 4738.09402 \\
\hline 236.59304 & 4738.09414 \\
\hline 236.59362 & 4738.09435 \\
\hline 236.59478 & 4738.09470 \\
\hline 36.59592 & 4738.09511 \\
\hline 236.59648 & 4738.09525 \\
\hline 236.59760 & 4738.09556 \\
\hline 2236.59821 & 4738.09568 \\
\hline 2236.59938 & 4738.09606 \\
\hline 2236.60055 & 4738.09638 \\
\hline 2236.60168 & 4738.09678 \\
\hline 2236.60285 & 4738.09725 \\
\hline 2236.61074 & 4738.10009 \\
\hline 2236.61189 & 4738.10049 \\
\hline 2236.61250 & 4738.10068 \\
\hline 2236.61307 & 4738.10090 \\
\hline 2236.61365 & 4738.10105 \\
\hline 2236.61481 & 4738.10144 \\
\hline 2236.61590 & 4738.10189 \\
\hline 2236.61705 & 4738.10231 \\
\hline 2236.61764 & 4738.10255 \\
\hline 2236.61875 & 4738.10289 \\
\hline 2236.61989 & 4738.10330 \\
\hline 2236.62044 & 4738.10350 \\
\hline 2236.62103 & 4738.10372 \\
\hline 2236.62166 & 4738.10389 \\
\hline 2236.62220 & 4738.10414 \\
\hline 2236.62279 & 4738.10434 \\
\hline 2236.62328 & 4738.10457 \\
\hline 2236.62387 & 4738.10487 \\
\hline 2236.62445 & 4738.10513 \\
\hline 2236.62501 & 4738.10528 \\
\hline 2236.62552 & 4738.10547 \\
\hline 2236.62614 & 4738.10569 \\
\hline 2236.62669 & 4738.10580 \\
\hline 2236.62727 & 4738.10603 \\
\hline 2236.62823 & 4738.10641 \\
\hline 2236.62919 & 4738.10665 \\
\hline 2236.63013 & 4738.10688 \\
\hline 2236.63071 & 4738.10707 \\
\hline 2236.63121 & 4738.10737 \\
\hline 2236.63244 & 4738.10773 \\
\hline 2236.63295 & 4738.10794 \\
\hline 2236.63351 & 4738.10812 \\
\hline 2236.63405 & 4738.10832 \\
\hline 2236.63465 & 4738.10853 \\
\hline 2236.63575 & 4738.10901 \\
\hline 2236.63633 & 4738.10923 \\
\hline 2236.63690 & 4738.10944 \\
\hline 2236.63747 & 4738.10965 \\
\hline 2236.63803 & 4738.10988 \\
\hline 2236.63857 & 4738.11014 \\
\hline 2236.63967 & 4738.11065 \\
\hline & 4738110 \\
\hline
\end{tabular}

\begin{tabular}{|c|c|}
\hline 236.64075 & 4738.11110 \\
\hline 2236.64132 & 4738.11139 \\
\hline 2236.64189 & 4738.11158 \\
\hline 236.64272 & 4738.11199 \\
\hline 236.64353 & 4738.11241 \\
\hline 236.64410 & 4738.11265 \\
\hline 236.64463 & 4738.11290 \\
\hline 236.64518 & 4738.11316 \\
\hline 236.64574 & 4738.11336 \\
\hline 236.64627 & 4738.11363 \\
\hline 236.64680 & 4738.11390 \\
\hline 236.64736 & 4738.11411 \\
\hline 2236.64791 & 4738.11437 \\
\hline 2236.64848 & 4738.11456 \\
\hline 2236.64905 & 4738.11477 \\
\hline 2236.64955 & 4738.11502 \\
\hline 2236.65012 & 4738.11518 \\
\hline 2236.65093 & 4738.11557 \\
\hline 2236.65204 & 4738.11597 \\
\hline 2236.65290 & 4738.11647 \\
\hline 2236.65342 & 4738.11676 \\
\hline 2236.65398 & 4738.11702 \\
\hline 2236.65452 & 4738.11728 \\
\hline 2236.65509 & 4738.11757 \\
\hline 2236.65564 & 4738.11789 \\
\hline 2236.65615 & 4738.11815 \\
\hline 2236.65669 & 4738.11852 \\
\hline 2236.65724 & 4738.11884 \\
\hline 2236.65243 & 4738.10911 \\
\hline 2236.65187 & 4738.10887 \\
\hline 2236.65129 & 4738.10862 \\
\hline 2236.65072 & 4738.10835 \\
\hline 2236.65013 & 4738.10806 \\
\hline 2236.64958 & 4738.10779 \\
\hline 2236.64900 & 4738.10753 \\
\hline 2236.64845 & 4738.10723 \\
\hline 2236.64766 & 4738.10681 \\
\hline 2236.64682 & 4738.10645 \\
\hline 2236.64627 & 4738.10624 \\
\hline 2236.64577 & 4738.10590 \\
\hline 2236.64517 & 4738.10563 \\
\hline 2236.64461 & 4738.10529 \\
\hline 2236.64403 & 4738.10504 \\
\hline 2236.64292 & 4738.10453 \\
\hline 2236.64235 & 4738.10424 \\
\hline 2236.64178 & 4738.10398 \\
\hline 2236.64126 & 4738.10374 \\
\hline 2236.64067 & 4738.10354 \\
\hline 2236.63986 & 4738.10331 \\
\hline 2236.63895 & 4738.10293 \\
\hline 2236.63782 & 4738.10257 \\
\hline 2236.63721 & 4738.10238 \\
\hline 2236.63664 & 4738.10216 \\
\hline 2236.63608 & 4738.10198 \\
\hline 2236.63551 & 4738.10175 \\
\hline 2236.63495 & 4738.10159 \\
\hline 2236.63435 & 4738.10143 \\
\hline 2236.63378 & 4738.10120 \\
\hline 2236.63293 & 4738.10092 \\
\hline & \\
\hline
\end{tabular}




\begin{tabular}{|c|c|}
\hline 236.63095 & 4738.10022 \\
\hline 2236.63037 & 4738.10000 \\
\hline 2236.62979 & 4738.09979 \\
\hline 236.62920 & 4738.09968 \\
\hline 36.62805 & 4738.09935 \\
\hline 36.62686 & 4738.09892 \\
\hline 36.62625 & 4738.09876 \\
\hline 36.62575 & 4738.09850 \\
\hline 36.62517 & 4738.09834 \\
\hline 36.62459 & 4738.09807 \\
\hline 236.62398 & 4738.09787 \\
\hline 236.62292 & 4738.09741 \\
\hline 36.62229 & 4738.09726 \\
\hline 36.62172 & 4738.09702 \\
\hline 236.62120 & 4738.09683 \\
\hline 236.62009 & 4738.09649 \\
\hline 36.61888 & 4738.09614 \\
\hline 36.61833 & 4738.09597 \\
\hline 236.61773 & 4738.09578 \\
\hline 236.61657 & 4738.09542 \\
\hline 236.61597 & 4738.09529 \\
\hline 36.61538 & 4738.09505 \\
\hline 236.61485 & 4738.09479 \\
\hline 236.61424 & 4738.09460 \\
\hline 236.61370 & 4738.09436 \\
\hline 236.61312 & 4738.09419 \\
\hline 36.61255 & 4738.09390 \\
\hline 236.61198 & 4738.09376 \\
\hline 236.61145 & 4738.09346 \\
\hline 2236.61023 & 4738.09311 \\
\hline 236.60916 & 4738.09278 \\
\hline 2236.60857 & 4738.09257 \\
\hline 2236.60800 & 4738.09243 \\
\hline 2236.60686 & 4738.09195 \\
\hline 2236.60629 & 4738.09174 \\
\hline 2236.60571 & 4738.09154 \\
\hline 2236.60512 & 4738.09133 \\
\hline 2236.60456 & 4738.09110 \\
\hline 2236.60400 & 4738.09087 \\
\hline 2236.60287 & 4738.09045 \\
\hline 2236.60231 & 4738.09026 \\
\hline 2236.60174 & 4738.09002 \\
\hline 2236.60118 & 4738.08984 \\
\hline 2236.60058 & 4738.08961 \\
\hline 2236.60000 & 4738.08933 \\
\hline 2236.59891 & 4738.08894 \\
\hline 2236.59835 & 4738.08886 \\
\hline 2236.59703 & 4738.08857 \\
\hline 2236.59651 & 4738.08837 \\
\hline 2236.59542 & 4738.08794 \\
\hline 2236.57782 & 4738.08412 \\
\hline 2236.57669 & 4738.08372 \\
\hline 2236.57550 & 4738.08349 \\
\hline 2236.57437 & 4738.08317 \\
\hline 2236.57314 & 4738.08299 \\
\hline 2236.57255 & 4738.08283 \\
\hline 2236.57136 & 4738.08260 \\
\hline 2236.57023 & 4738.08237 \\
\hline 2236.56844 & 4738.08210 \\
\hline & 47380818 \\
\hline
\end{tabular}

\begin{tabular}{|c|c|}
\hline 236.56607 & 4738.08159 \\
\hline 2236.56553 & 4738.08147 \\
\hline 236.56437 & 4738.08125 \\
\hline 236.56317 & 4738.08085 \\
\hline 236.56195 & 4738.08073 \\
\hline 236.56077 & 4738.08049 \\
\hline 36.55608 & 4738.07937 \\
\hline 236.55495 & 4738.07917 \\
\hline 36.55409 & 4738.07910 \\
\hline 236.55313 & 4738.07882 \\
\hline 236.55255 & 4738.07869 \\
\hline 236.55195 & 4738.07855 \\
\hline 236.55075 & 4738.07838 \\
\hline 2236.54963 & 4738.07811 \\
\hline 2236.54904 & 4738.07801 \\
\hline 2236.54850 & 4738.07785 \\
\hline 2236.54730 & 4738.07758 \\
\hline 2236.53036 & 4738.07353 \\
\hline 2236.52918 & 4738.07327 \\
\hline 2236.52856 & 4738.07315 \\
\hline 2236.52735 & 4738.07288 \\
\hline 2236.52619 & 4738.07272 \\
\hline 2236.52441 & 4738.07236 \\
\hline 2236.52324 & 4738.07218 \\
\hline 2236.52206 & 4738.07192 \\
\hline 2236.52146 & 4738.07182 \\
\hline 2236.52027 & 4738.07155 \\
\hline 2236.51910 & 4738.07131 \\
\hline 2236.51790 & 4738.07097 \\
\hline 2236.51732 & 4738.07084 \\
\hline 2236.51523 & 4738.07058 \\
\hline 2236.51383 & 4738.07000 \\
\hline 2236.51268 & 4738.06968 \\
\hline 2236.51209 & 4738.06954 \\
\hline 2236.51151 & 4738.06936 \\
\hline 2236.51035 & 4738.06904 \\
\hline 2236.50974 & 4738.06885 \\
\hline 2236.50857 & 4738.06857 \\
\hline 2236.50800 & 4738.06836 \\
\hline 2236.50743 & 4738.06828 \\
\hline 2236.50627 & 4738.06787 \\
\hline 2236.50569 & 4738.06778 \\
\hline 2236.50453 & 4738.06742 \\
\hline 2236.50394 & 4738.06721 \\
\hline 2236.50336 & 4738.06710 \\
\hline 2236.50280 & 4738.06691 \\
\hline 2236.50154 & 4738.06660 \\
\hline 2236.50045 & 4738.06622 \\
\hline 2236.49926 & 4738.06601 \\
\hline 2236.49866 & 4738.06585 \\
\hline 2236.49749 & 4738.06559 \\
\hline 2236.49691 & 4738.06540 \\
\hline 2236.49574 & 4738.06501 \\
\hline 2236.49517 & 4738.06484 \\
\hline 2236.47833 & 4738.06052 \\
\hline 2236.47716 & 4738.06025 \\
\hline 2236.47602 & 4738.05998 \\
\hline 2236.47541 & 4738.05980 \\
\hline 2236.47485 & 4738.05963 \\
\hline & 4738050 \\
\hline
\end{tabular}

\begin{tabular}{|c|c|}
\hline 36.4724 & 4738.0590 \\
\hline 2236.47186 & 4738.05898 \\
\hline 2236.47125 & 4738.05876 \\
\hline 236.46835 & 4738.05245 \\
\hline 236.46896 & 4738.05263 \\
\hline 236.47015 & 4738.05295 \\
\hline 236.47073 & 4738.05319 \\
\hline 236.47130 & 4738.05336 \\
\hline 236.47190 & 4738.05351 \\
\hline 236.47305 & 4738.05376 \\
\hline 236.47425 & 4738.05406 \\
\hline 236.47487 & 4738.05417 \\
\hline 236.47603 & 4738.05447 \\
\hline 236.47717 & 4738.05497 \\
\hline 236.47838 & 4738.05510 \\
\hline 2236.47893 & 4738.05525 \\
\hline 236.48015 & 4738.05550 \\
\hline 236.49949 & 4738.06043 \\
\hline 236.50090 & 4738.06078 \\
\hline 236.50217 & 4738.06118 \\
\hline 236.50359 & 4738.06137 \\
\hline 236.50422 & 4738.06150 \\
\hline 2236.50538 & 4738.06177 \\
\hline 2236.50596 & 4738.06191 \\
\hline 2236.50716 & 4738.06218 \\
\hline 2236.50830 & 4738.06249 \\
\hline 2236.50953 & 4738.06283 \\
\hline 2236.51006 & 4738.06304 \\
\hline 2236.51121 & 4738.06329 \\
\hline 2236.51249 & 4738.06353 \\
\hline 2236.51364 & 4738.06391 \\
\hline 2236.51476 & 4738.06420 \\
\hline 2236.51538 & 4738.06435 \\
\hline 2236.51714 & 4738.06479 \\
\hline 2236.51834 & 4738.06506 \\
\hline 2236.51949 & 4738.06534 \\
\hline 2236.52064 & 4738.06557 \\
\hline 2236.52184 & 4738.06577 \\
\hline 2236.52368 & 4738.06594 \\
\hline 2236.52503 & 4738.06628 \\
\hline 2236.52664 & 4738.06641 \\
\hline 2236.52788 & 4738.06667 \\
\hline 2236.52906 & 4738.06694 \\
\hline 2236.53086 & 4738.06712 \\
\hline 2236.53262 & 4738.06741 \\
\hline 2236.53442 & 4738.06780 \\
\hline 2236.53621 & 4738.06807 \\
\hline 2236.53918 & 4738.06849 \\
\hline 2236.54623 & 4738.06986 \\
\hline 2236.54737 & 4738.07015 \\
\hline 2236.54862 & 4738.07036 \\
\hline 2236.54979 & 4738.07064 \\
\hline 2236.55083 & 4738.07090 \\
\hline 2236.55215 & 4738.07116 \\
\hline 2236.55268 & 4738.07129 \\
\hline 2236.55331 & 4738.07144 \\
\hline 2236.55451 & 4738.07172 \\
\hline 2236.55563 & 4738.07203 \\
\hline 2236.55624 & 4738.07213 \\
\hline & 807232 \\
\hline
\end{tabular}




\begin{tabular}{|c|c|c|c|c|}
\hline 2236.56499 & 4738.07424 & E & 2236.63426 & 4738.09482 \\
\hline 2236.56559 & 4738.07438 & $\mathrm{E}$ & 2236.63486 & 4738.09499 \\
\hline 236.56734 & 4738.07484 & A & 2236.63996 & 4738.09674 \\
\hline 2236.56794 & 4738.07503 & A & 2236.64050 & 4738.09697 \\
\hline 236.56912 & 4738.07531 & A & 2236.64107 & 4738.09720 \\
\hline 236.56970 & 4738.07544 & A & 2236.64164 & 4738.09742 \\
\hline 236.57089 & 4738.07572 & A & 2236.64221 & 4738.09769 \\
\hline 36.57202 & 4738.07600 & A & 2236.64276 & 4738.09792 \\
\hline 236.57312 & 4738.07639 & A & 2236.64331 & 4738.09819 \\
\hline 236.57435 & 4738.07659 & A & 2236.64390 & 4738.09846 \\
\hline 236.57489 & 4738.07679 & A & 2236.64443 & 4738.09877 \\
\hline 236.57605 & 4738.07707 & A & 2236.64658 & 4738.09985 \\
\hline 2236.57668 & 4738.07721 & A & 2236.64712 & 4738.10013 \\
\hline 236.57783 & 4738.07756 & A & 2236.64761 & 4738.10043 \\
\hline 236.57836 & 4738.07773 & A & 2236.64818 & 4738.10075 \\
\hline 236.57957 & 4738.07801 & A & 2236.64872 & 4738.10098 \\
\hline 236.58017 & 4738.07810 & $\mathrm{E}$ & 2236.64923 & 4738.10120 \\
\hline 236.58130 & 4738.07831 & $\mathrm{E}$ & 2236.64969 & 4738.10149 \\
\hline 236.58247 & 4738.07855 & $\mathrm{E}$ & 2236.65031 & 4738.10176 \\
\hline 236.58367 & 4738.07880 & $\mathrm{E}$ & 2236.65086 & 4738.10203 \\
\hline 2236.58483 & 4738.07909 & E & 2236.65139 & 4738.10232 \\
\hline 2236.58539 & 4738.07927 & E & 2236.65191 & 4738.10263 \\
\hline 2236.58657 & 4738.07952 & $\mathrm{E}$ & 2236.65248 & 4738.10287 \\
\hline 2236.58776 & 4738.07972 & $\mathrm{E}$ & 2236.65301 & 4738.10315 \\
\hline 2236.58892 & 4738.08004 & $\mathrm{E}$ & 2236.65360 & 4738.10339 \\
\hline 2236.58949 & 4738.08017 & $\mathrm{E}$ & 2236.65418 & 4738.10372 \\
\hline 2236.59004 & 4738.08036 & $\mathrm{E}$ & 2236.65524 & 4738.10429 \\
\hline 2236.59122 & 4738.08062 & E & 2236.65579 & 4738.10453 \\
\hline 2236.61032 & 4738.08614 & $\mathrm{D}$ & 2236.65634 & 4738.10478 \\
\hline 2236.61119 & 4738.08650 & $\mathrm{D}$ & 2236.63136 & 4738.08860 \\
\hline 2236.61209 & 4738.08664 & $\mathrm{D}$ & 2236.63019 & 4738.08830 \\
\hline 2236.61259 & 4738.08696 & $\mathrm{D}$ & 2236.62902 & 4738.08798 \\
\hline 2236.61320 & 4738.08717 & $\mathrm{D}$ & 2236.62782 & 4738.08773 \\
\hline 2236.61378 & 4738.08738 & $\mathrm{D}$ & 2236.62680 & 4738.08746 \\
\hline 2236.61509 & 4738.08794 & $\mathrm{D}$ & 2236.59685 & 4738.07546 \\
\hline 2236.61603 & 4738.08836 & $\mathrm{D}$ & 2236.59574 & 4738.07504 \\
\hline 2236.61660 & 4738.08853 & $\mathrm{D}$ & 2236.59452 & 4738.07471 \\
\hline 2236.61715 & 4738.08875 & $\mathrm{D}$ & 2236.59394 & 4738.07454 \\
\hline 2236.61773 & 4738.08891 & $\mathrm{D}$ & 2236.59337 & 4738.07440 \\
\hline 2236.61833 & 4738.08910 & $\mathrm{D}$ & 2236.59217 & 4738.07415 \\
\hline 2236.61892 & 4738.08929 & $\mathrm{D}$ & 2236.59098 & 4738.07391 \\
\hline 2236.62009 & 4738.08963 & $\mathrm{D}$ & 2236.58961 & 4738.07384 \\
\hline 2236.62064 & 4738.08980 & $\mathrm{D}$ & 2236.58858 & 4738.07365 \\
\hline 2236.62116 & 4738.08997 & $\mathrm{D}$ & 2236.58746 & 4738.07334 \\
\hline 2236.62458 & 4738.09117 & $\mathrm{E}$ & 2236.58688 & 4738.07309 \\
\hline 2236.62520 & 4738.09139 & A & 2236.58629 & 4738.07292 \\
\hline 2236.62574 & 4738.09166 & A & 2236.58509 & 4738.07276 \\
\hline 2236.62630 & 4738.09187 & A & 2236.58392 & 4738.07255 \\
\hline 2236.62688 & 4738.09212 & A & 2236.58278 & 4738.07227 \\
\hline 2236.62746 & 4738.09238 & A & 2236.58100 & 4738.07192 \\
\hline 2236.62800 & 4738.09259 & A & 2236.57918 & 4738.07164 \\
\hline 2236.62859 & 4738.09276 & $\mathrm{D}$ & 2236.57742 & 4738.07142 \\
\hline 2236.62859 & 4738.09276 & $\mathrm{E}$ & 2236.57562 & 4738.07116 \\
\hline 2236.62977 & 4738.09311 & $\mathrm{D}$ & 2236.57322 & 4738.07084 \\
\hline 2236.63030 & 4738.09337 & $\mathrm{D}$ & 2236.57141 & 4738.07068 \\
\hline 2236.63110 & 4738.09375 & $\mathrm{D}$ & 2236.57024 & 4738.07040 \\
\hline 2236.63200 & 4738.09395 & $\mathrm{D}$ & 2236.56903 & 4738.07013 \\
\hline 2236.63256 & 4738.09420 & D & 2236.56843 & 4738.07005 \\
\hline 2236.63317 & 4738.09435 & $\mathrm{D}$ & 2236.56668 & 4738.06971 \\
\hline 2236.63371 & 4738.09461 & D & 2236.55593 & 4738.06790 \\
\hline
\end{tabular}

\begin{tabular}{|c|c|}
\hline $00.534 / 0$ & $4 / 38.06 / 68$ \\
\hline 36.55359 & 4738.06745 \\
\hline 2236.55237 & 4738.06720 \\
\hline 2236.55176 & 4738.06705 \\
\hline 36.55035 & 4738.06691 \\
\hline 2236.54883 & 4738.06665 \\
\hline 2236.54748 & 4738.06652 \\
\hline 36.54035 & 4738.06563 \\
\hline 36.53801 & 4738.06533 \\
\hline 36.53505 & 4738.06485 \\
\hline 36.53263 & 4738.06463 \\
\hline 36.53023 & 4738.06436 \\
\hline 36.52783 & 4738.06407 \\
\hline 36.52606 & 4738.06381 \\
\hline 36.52425 & 4738.06343 \\
\hline 36.52307 & 4738.06323 \\
\hline 36.52187 & 4738.06296 \\
\hline 2236.52129 & 4738.06279 \\
\hline 36.52008 & 4738.06252 \\
\hline 36.51834 & 4738.06215 \\
\hline 36.51777 & 4738.06200 \\
\hline 36.51717 & 4738.06185 \\
\hline 36.51660 & 4738.06165 \\
\hline 36.51543 & 4738.06143 \\
\hline 36.51427 & 4738.06117 \\
\hline 36.51309 & 4738.06093 \\
\hline 36.51192 & 4738.06077 \\
\hline 36.51007 & 4738.06044 \\
\hline 36.50888 & 4738.06017 \\
\hline 6.50828 & 4738.06002 \\
\hline 36.50769 & 4738.05983 \\
\hline 36.50709 & 4738.05963 \\
\hline 36.50650 & 4738.05945 \\
\hline 36.50531 & 4738.05906 \\
\hline 36.50408 & 4738.05879 \\
\hline 36.50299 & 4738.05843 \\
\hline 36.50241 & 4738.05828 \\
\hline 236.50182 & 4738.05809 \\
\hline 36.50067 & 4738.05778 \\
\hline 36.47708 & 4738.04995 \\
\hline 36.47651 & 4738.04975 \\
\hline 36.47596 & 4738.04949 \\
\hline 36.47537 & 4738.04929 \\
\hline 36.47478 & 4738.04910 \\
\hline 36.47364 & 4738.04879 \\
\hline 36.47309 & 4738.04860 \\
\hline 36.47258 & 4738.04841 \\
\hline 36.47197 & 4738.04821 \\
\hline 2236.47143 & 4738.04796 \\
\hline 2236.47085 & 4738.04776 \\
\hline 36.46968 & 4738.04726 \\
\hline 2236.46852 & 4738.04682 \\
\hline 13646706 & 4738.04660 \\
\hline 2236.46741 & 4738.04632 \\
\hline 2236.46658 & 4738.04605 \\
\hline 36.46579 & 4738.04564 \\
\hline 2236.56859 & 4738.06580 \\
\hline 36.56993 & 4738.06612 \\
\hline 5.57150 & 4738.06627 \\
\hline 6.57257 & 4738.06647 \\
\hline
\end{tabular}




$\begin{array}{lll}2236.57385 & 4738.06673 & \text { A } \\ 2236.57508 & 4738.06690 & \text { A } \\ 2236.57645 & 4738.06707 & \text { A } \\ 2236.57782 & 4738.06733 & \text { A } \\ 2236.57914 & 4738.06750 & \text { A } \\ 2236.58059 & 4738.06750 & \text { A } \\ 2236.58196 & 4738.06762 & \text { A } \\ 2236.58298 & 4738.06775 & \text { A } \\ 2236.58431 & 4738.06801 & \text { A } \\ 2236.58555 & 4738.06809 & \text { A } \\ 2236.58674 & 4738.06826 & \text { A } \\ 2236.58790 & 4738.06835 & \text { A } \\ 2236.58922 & 4738.06861 & \text { A } \\ 2236.59041 & 4738.06886 & \text { A } \\ 2236.59161 & 4738.06916 & \text { A } \\ 2236.59272 & 4738.06955 & \text { A } \\ 2236.59375 & 4738.06984 & \text { A } \\ 2236.59477 & 4738.07014 & \text { A } \\ 2236.59567 & 4738.07036 & \text { A } \\ 2236.59648 & 4738.07061 & \text { A } \\ 2236.59738 & 4738.07100 & \text { A } \\ 2236.59819 & 4738.07121 & \text { A } \\ 2236.59900 & 4738.07151 & \text { A }\end{array}$




\section{REFERÊNCIAS BIBLIOGRÁFICAS}

ACKROYD, N.; LORIMER, R. Global navigation: a GPS user's guide. 2. ed. London: Lloyd's of London Press, 1994. 196p.

ALGERBO, P.A.; THYLEN, L. Coast guard beacon system. In: EUROPEAN CONFERENCE ON PRECISION AGRICULTURE '97, 1., Warwick, 1997. Proceedings. London: BIOS Scientific Publications, 1997. p.545-550.

ALVES, V.C. Desempenho de herbicidas na cultura de milho (Zea mays L.). Piracicaba, 2001. 92p. Tese (Doutorado) - Escola Superior de Agricultura "Luiz de Queiroz", Universidade de São Paulo.

ANTUNIASSI, U.R.; MILLER, P.C.H.; PAICE, M.E.R. Sistemas de injeção para a aplicação localizada de defensivos. In: BALASTREIRE, L.A. (Ed.). O estado-daarte da agricultura de precisão no Brasil. Piracicaba: ESALQ, 2000. p.157-164.

ANTUNIASSI, U.R.; GADANHA JUNIOR., C.D. Aplicação localizada de produtos fitossanitários. In: BORÉM, A.; GIÚDICE, M.P.; QUEIROZ, D.M.; MANTOVANI, E.C.; FERREIRA, L.R.; VALLE, F.X.R. do; GOMIDE, R.L. (Ed.). Agricultura de Precisão. Viçosa: UFV, 2000. p.181-202.

BALASTREIRE, L.A. Aplicação Localizada de Insumos - ALI: um velho conceito novo. In: CONGRESSO BRASILEIRO DE ENGENHARIA AGRÍCOLA, 23., Campinas, 1994. Anais. Campinas: SBEA, 1994. p.248. 
BALASTREIRE, L.A. Agricultura de precisão. Piracicaba: L.A. Balastreire, 1998. $81 \mathrm{p}$.

BALASTREIRE, L.A.; BAIO, F.H.R. Avaliação da acurácia de um GPS com correção por algoritmo comparado com um sistema DGPS. /Apresentado como pôster ao III Simpósio sobre Agricultura de Precisão, Piracicaba, 2001a./

BALASTREIRE, L.A.; BAIO, F.H.R. Avaliação de uma metodologia prática para o mapeamento de plantas daninhas. Revista Brasileira de Engenharia Agrícola e Ambiental, v.5, n.2, p.349-352, 2001 b.

BALASTREIRE, L.A.; BAIO, F.H.R. Avaliação de um sistema para aplicação localizada de defensivos baseado na variabilidade espacial de plantas daninhas. /Apresentado como pôster ao III Simpósio sobre Agricultura de Precisão, Piracicaba, 2001c./

BALASTREIRE, L.A.; ELIAS, A.I.; AMARAL, J.R. do. Agricultura de Precisão: mapeamento da cultura do milho. Revista Engenharia Rural, v.8, n.1, p.97-111, 1997.

BILLER, R.H., HOLLSTEIN, C., SOMMER, C. Precision aplication of herbicides by use of optoeletronic sensors. In: EUROPEAN CONFERENCE ON PRECISION AGRICULTURE '97, 1., Warwick, 1997. Proceedings. London: BIOS Scientific Publications, 1997. p.451-457.

BLACKMORE, B.S.; LARSCHEID, G. Strategies for managing variability. In: EUROPEAN CONFERENCE ON PRECISION AGRICULTURE '97, 1., Warwick, 1997. Proceedings. London: BIOS Scientific Publications, 1997. p.851-859. 
CHRISTENSEN, S.; HEISEL, T.; BENLLOCH, J.V. Patch spraying and rational weed mapping in cereals. In: INTERNATIONAL CONFERENCE ON PRECISION AGRICULTURE, 4., Minneapolis, 1998. Proceedings. Madison: ASA; CSSA, SSSA, 1999. p.773-785.

CLARK, R.L.; MCGUCKIN, R.L. Variable rate application technology: an overview. In: INTERNATIONAL CONFERENCE ON PRECISION AGRICULTURE, 3., Minneapolis, 1996. Proceedings. Madison: ASA; CSSA, SSSA, 1996. p.855-862.

CLAY, S.A.; LEMS. G.J.; CLAY, D.E.; ELLSBURY, M.M.; FORCELLA, F. Targeting precision agrichemical applications to increase productivity. In: INTERNATIONAL CONFERENCE ON PRECISION AGRICULTURE, 4., Mineapolis, 1998. Proceedings. Madison: ASA; CSSA, SSSA, 1999. p.16991718.

COLLIVER, C.T., MAXWELL, B.D., TYLER, D.A., ROBERTS, D.W., LONG, D.S. Georeferencing Wild Oat Infestations in Small Grains: Accuracy and Efficiency of Three Survey Techniques. In: INTERNATIONAL CONFERENCE ON PRECISION AGRICUlTURE, 3., Minneapolis, 1996. Proceedings. Madison: ASA; CSSA, SSSA, 1996. p.453-463.

DAMPNEY, P.M.R.; MOORE, M. Precision Agriculture in England: current practice and research-based advice to farmers. In: INTERNATIONAL CONFERENCE ON PRECISION AGRICUltURE, 4., Mineapolis, 1998. Proceedings. Madison: ASA; CSSA, SSSA, 1999. p.661-673.

DIAS, A.S. Desenvolvendo em Borland $\mathbf{C}^{++}$Builder 5.0. Rio de Janeiro: Ed. Ciência Moderna, 2000. 193p. 
ELLSBURY, M.M.; WOODSON, W.D.; CHANDLER, L.D.; CLAY, S.A.; CLAY, D.E.; MALO, D.; SCHUMACHER, T.; SCHUMACHER, J.; CARLSON, C.G. Spatial characterization of adult emergence patterns and oviposition for corn rootworm populations in continuous and rotated corn. In: EUROPEAN CONFERENCE ON PRECISION AGRICULTURE '97, 1., Warwick, 1997. Proceedings. London: BIOS Scientific Publications, 1997. p.227-234.

ESCOLA SUPERIOR DE AGRICULTURA "LUIZ DE QUEIROZ”. Normas para elaboração de dissertações e teses. 2. ed., Piracicaba: ESALQ, 1997. 94 p.

FEYAERTS, F.; POLLET, P.; VAN GOOL, L.; WAMBACQ, P. Sensor for weed detection based on spectral measurements. In: INTERNATIONAL CONFERENCE ON PRECISION AGRICUltURE, 4., Mineapolis, 1998. Proceedings. Madison: ASA; CSSA, SSSA, 1999. p.1537-1548.

FNP CONSULTORIA \& COMÉRCIO Agrianual 2001: anuário da agricultura brasileira. São Paulo, 2001. 545p.

FRANCIS, D.D.; SCHEPERS, J.S. Selective soil sampling for site-specific nutrient management. In: EUROPEAN CONFERENCE ON PRECISION AGRICULTURE '97, 1., Warwick, 1997. Proceedings. London: BIOS Scientific Publications, 1997. p.119-126.

GELMINI, G.A. Herbicidas: indicações básicas. Campinas: Fundação Cargill, 1988. $334 p$. 
GERHARDS, R.; SÖKEFELD, M.; TIMMERMANN, C.; REICHART, S.; KÜHBAUCH, W.; WILLIAMS II, M. M. Results of a four-year study on sitespecific herbicide application. In: EUROPEAN CONFERENCE ON PRECISION AGRICULTURE ‘99, 2., Odense, 1999. Proceedings. London: Sheffield Academic Press, 1999. p. 689-697.

GERHARDS, R.; WYSE-PESTER, D.Y.; MORTESEN, D.A. Spatial stability of weed patches in agricultural fields. In: INTERNATIONAL CONFERENCE ON PRECISION AGRICULTURE, 3., Minneapolis, 1996. Proceedings. Madison: ASA; CSSA, SSSA, 1996. p.495-504.

GOERING, C.E. Recycling a concept. Agricultural Engineering, v.74, p.25, 1993.

GREEN, H.M., VENCILL, W.K., KVIEN, C.K., BOYDELL, B.C., POCKNEE, S. Precision management of spaciality variable weeds. In: EUROPEAN CONFERENCE ON PRECISION AGRICULTURE '97, 1., Warwick, 1997. Proceedings. London: BIOS Scientific Publications, 1997. p.983-989.

HAGUE, T.; MARCHANT, J.A.; TILLET, N.D. Ground based sensing systems for autonomous agricultural vehicles. Computers and Electronics in Agriculture, v.25, p.11-28, 2000.

HARTSOCK, N.J.; MUELLER, T.G.; THOMAS, G.W.; BARNHISEL, R.I.; WELLS, K. L.; SHEARER, S.A. Soil electrical conductivity variability. (compact disc). In: INTERNATIONAL CONFERENCE ON PRECISION AGRICULTURE，5., Milwaukee, 2000. Proceedings. Madison: ASA; CSSA, SSSA, 2000. 
HEISEL, T.; CHRISTENSEN, S. A digital camera system for weed detection. In: INTERNATIONAL CONFERENCE ON PRECISION AGRICULTURE, 4., Mineapolis, 1998. Proceedings. Madison: ASA; CSSA, SSSA, 1999. p.1569-1577. HEISEL, T; ANDREASEN, C; ERSBOLL, A.K. Annual weed distributions can be mapped with kriging. Weed Research, v.36, p.325-337, 1996a.

HEISEL, T.; CHRISTENSEN, S.; WALTER, A.M. Weeds managing model for patch spraying in cereal. In: INTERNATIONAL CONFERENCE ON PRECISION AGRICUlTURE, 3., Minneapolis, 1996. Proceedings. Madison: ASA; CSSA, SSSA, 1996b. p.999-1005.

HEISEL, T.; CHRISTENSEN, S.; WALTER, A. M. Validation of weed patch spraying in spring barley - preliminary trial. In: EUROPEAN CONFERENCE ON PRECISION AGRICULTURE '97, 1., Warwick, 1997. Proceedings. London: BIOS Scientific Publications, 1997. p.879-886.

HEISEL, T.; CHRISTENSEN, S.; WALTER, A. M. Whole-field experiments with sitespecific weed management. In: EUROPEAN CONFERENCE ON PRECISION AGRICUlTURE '99, 2., Odense, 1999. Proceedings. London: Sheffield Academic Press, 1999. p.759-768.

KENNEDY, M. The Global Positioning System and GIS: an introduction. Chelsea: Ann Arbor Press, 1996. 268p.

KOLPIN, D.W.; THURMAN, E.M.; LINHART, S.M. Finding minimal herbicide concentration in ground water? Try looking for their degradates. The Science of the Total Environmental, v.248, p.235-247, 2000.

LANÇAS, K.P.; CASTRO NETO, P.; NAGAOKA, A.K.; GUERRA, S.P.S. Índice de cone e mapas de isocompactação do solo agrícola obtidos com a utilização de um 
penetrômetro hidráulico-eletrônico e um sistema de posicionamento global diferencial (DGPS). In: BALASTREIRE, L.A. (Ed.). O estado-da-arte da agricultura de precisão no Brasil. Piracicaba: ESALQ, 2000. p.113-123.

LIPPERT, R.M.; WOLAK, F.J. Weed mapping and assessment of broadcast vs. spot treatment of sicklepod weeds in soybeans. In: EUROPEAN CONFERENCE ON PRECISION AGRICULTURE '99, 2., Odense, 1999. Proceedings. London: Sheffield Academic Press, 1999. p.223-227.

LECHNER, W.; BAUMANN, S. Global navigations satellites systems. Computers and Electronics in Agriculture, v.25, p.67-85, 2000.

LORENZI, H. Manual de identificação e controle de plantas daninhas: plantio direto e convencional. 5. ed. Nova Odessa, SP: Instituto Plantarum, 2000. 339p.

LEICK, A. GPS satellite surveying. 2. ed. New York: John Wiley, 1995. 560p.

MACK, G. Precise positioning for agriculture. In: EUROPEAN CONFERENCE ON PRECISION AGRICULTURE '97, 1., Warwick, 1997. Proceedings. London: BIOS Scientific Publications, 1997. p.593-602.

MCBRATNEY A.B.; PRINGLE, M.J. Spatial variability in soil - implications for Precision Agriculture. In: EUROPEAN CONFERENCE ON PRECISION AGRICUltURE '97, 1., Warwick, 1997. Proceedings. London: BIOS Scientific Publications, 1997. p.3-31.

MORGAN, G.D.; BINNING, L.K.; MACGUIDWIN, A.E. Spatial variability of root lesion nematodes (Pratylenchus penetrans) in potatoes. (compact disc). In: INTERNATIONAL CONFERENCE ON PRECISION AGRICULTURE, 5., Milwaukee, 2000. Proceedings. Madison: ASA; CSSA, SSSA, 2000. 
MORTENSEN, D.A.; JOHNSON, G.A.; WYSE, D.Y.; MARTIN, A.R. Managing spatially variable weed populations. In: ANNUAL CONFERENCE OF SITESPECIFIC MANAGEMENT FOR AGRICULTURAL SYSTEMS, 2., Minneapolis, 1994. Proceedings. Madison: ASA-CSSA-SSSA, 1995. p.397-416.

NORDMEYER, H.; DUNKER, M. Variable weed densities and soil properties in a weed mapping concept for patchy weed control. In: EUROPEAN CONFERENCE ON PRECISION AGRICULTURE '99, 2., Odense, 1999. Proceedings. London: Sheffield Academic Press, 1999. p.453-462.

NORDMEYER, H.; HÄUSLER, A.; NIEMANN, P. Patchy weed control as an approach in precise farming. In: EUROPEAN CONFERENCE ON PRECISION AGRICULTURE '97, 1., Warwick, 1997. Proceedings. London: BIOS Scientific Publications, 1997. p.307-314.

OSTP Statement by the President regarding the United States' decision to stop degrading Global Positioning System accuracy. http://www.ostp.gov/html/0053_2.html. 2000.

PAICE, M.E.R.; MILLER, P.C.H; BODLE, J.D. An experimental sprayer for the selective application of herbicides. Journal of Agricultural Engineering Research, v.60, p.107-116, 1995.

PAICE, M.E.R.; MILLER, P.C.H; DAY, W. Control requirements for spatially selective herbicides sprayers. Computers and Electronics in Agriculture, v.14, p.163-177, 1996. 
REW, L.J.; CUSSANS, G.W.; MUGGLESTONE, M.A.; MILLER, P.C.H. A technique for mapping the spatial distribution of Elymus repens, with estimates of the potential reduction in herbicide usage from patch spraying. Weed Research, v.36, n..4, p.283292, 1996.

SCARR, M.R.; TAYLOR, C.C.; DRYDEN, I.L. Automatic recognition of weeds and crops. In: EUROPEAN CONFERENCE ON PRECISION AGRICULTURE '97, 1., Warwick, 1997. Proceedings. London: BIOS Scientific Publications, 1997. p.429437.

SCHWARZ, J.; WARTENBERG, G; ACKERMANN, I. Process-engineering investigations for site-specific weed control. In: EUROPEAN CONFERENCE ON PRECISION AGRICULTURE '99, 2., Odense, 1999. Proceedings. London: Sheffield Academic Press, 1999. p.699-707.

SEARCY, S.W. Agricultura de Precisão: um desafio para a extensão e educação continuada. In: BALASTREIRE, L.A. (Ed.). O estado-da-arte da agricultura de precisão no Brasil. Piracicaba: ESALQ, 2000. p.17-24.

SILVA, J.F. Defensivos agrícolas: utilização, toxicologia e legislação específica. Brasília: ABEAS, 1983. 161p.

SILVA JUNIOR, R.L. Variabilidade espacial do índice de cone correlacionada com mapas de produtividade. Piracicaba, 2001. 132p. Dissertação (Mestrado) - Escola Superior de Agricultura “Luiz de Queiroz”, Universidade de São Paulo. 
STAFFORD, J.V. Implementing precision agriculture in the 21st. Century. Journal of Agricultural Research, v.76, p.267-275, 2001.

STAFFORD, J.V.; AMBLER, B. In-field location using GPS for spatially variable field operations. Computers and Electronics in Agriculture, v.11, p.23-26, 1994.

STAFFORD, J.V., BENLLOCH, J.V. Machine-assisted detection of weeds and weed patches. In: EUROPEAN CONFERENCE ON PRECISION AGRICULTURE '97, 1., Warwick, 1997. Proceedings. London: BIOS Scientific Publications, 1997. p.511-518.

STAFFORD, J.V.; LE BARS, J.M.; AMBLER, B. A hand-held data logger with integral GPS for producing weed maps by field walks. Computers and Electronics in Agriculture, v.14, p.235-247, 1996.

STAFFORD, J.V.; MILLER, P.C.H. Spatially selective application of herbicide to cereal crops. Computers and Electronics in Agriculture, v.9, p.217-229, 1993.

STAFFORD, J.V.; MILLER, P.C.H. Spacitially variable treatment of weed patches. In: INTERNATIONAL CONFERENCE ON PRECISION AGRICULTURE, 3., Minneapolis, 1996. Proceedings. Madison: ASA; CSSA, SSSA, 1996. p.465-474.

TIAN, L.; REID, J.F.; HUMMEL, J.W. Development of a precision sprayer for sitespecific weed management. Transactions of the ASAE, v.42, n.4. p.893-900, 1999.

VIEIRA, S. R. Geoestatística aplicada a agricultura de precisão. In: BORÉM, A.; GIÚDICE，M.P.; QUEIROZ，D.M.; MANTOVANI， E.C.; FERREIRA， L.R.; VALLE, F.X.R. do; GOMIDE, R.L. (Ed.). Agricultura de precisão. Viçosa: UFV, 2000. p.93-108. 
VOLL E. Agricultura de Precisão: Manejo de plantas daninhas. In: BORÉM, A.; GIÚDICE, M.P.; QUEIROZ, D.M.; MANTOVANI, E.C.; FERREIRA, L.R.; VALE, F.X.R. do; GOMIDE, R.L. (Ed.). Agricultura de precisão. Viçosa: UFV, 2000. p.203-235.

VRINDTS, E.; DE BAERDEMAEKER, J. Optical discrimination of crops, weed and soil for on-line weed detection. In: EUROPEAN CONFERENCE ON PRECISION AGRICULTURE '97, 1., Warwick, 1997. Proceedings. London: BIOS Scientific Publications, 1997. p.537-510.

VRINDTS, E.; DE BAERDEMAEKER, J; RAMON, H. Weed detection using canopy reflectance. In: EUROPEAN CONFERENCE ON PRECISION AGRICULTURE '99, 2., Odense, 1999. Proceedings. London: Sheffield Academic Press, 1999. p.257-264.

WALTER, A.M.; HEISEL, T.; CHRISTENSEN, S. Shortcuts in weed mapping. In: EUROPEAN CONFERENCE ON PRECISION AGRICULTURE '97, 1., Warwick, 1997. Proceedings. London: BIOS Scientific Publications, 1997. p.777-784.

WILES, L. J.; SCHWEIZER, E. E. Mapping weed populations: the cost of counting and identifying seedlings and seeds. In: INTERNATIONAL CONFERENCE ON PRECISION AGRICUlTURE, 4., Mineapolis, 1998. Proceedings. Madison: ASA; CSSA, SSSA, 1999. p.499-509. 
WILLIAMS II, M.M.; GERHARDS, G.; MORTENSEN, D.A. Spatiotemporal outcomes of site-specific weed management in maize. In: EUROPEAN CONFERENCE ON PRECISION AGRICULTURE '99, 2., Odense, 1999. Proceedings. London: Sheffield Academic Press, 1999. p.897-907.

WILLIAMS II, M. M.; GERHARDS, R.; MORTESEN D. A.; REICHART, S.; MARTIN, A. R. Weed seedling population responses to a method of site-specific weed management. In: INTERNATIONAL CONFERENCE ON PRECISION AGRICUlTURE, 4., Mineapolis, 1998. Proceedings. Madison: ASA; CSSA, SSSA, 1999. p.123-132.

WILSON, B.J.; BRAIN, P. Long-term stability of distribution of Alopecurus myosuroides Huds. within cereal fields. Weed Research, v.31, n..6, p.367-373, 1991. 